NBER WORKING PAPER SERIES

\title{
CORPORATE GOVERNANCE, ECONOMIC ENTRENCHMENT AND GROWTH
}

\author{
Randall Morck \\ Daniel Wolfenzon \\ Bernard Yeung \\ Working Paper 10692 \\ http://www.nber.org/papers/w10692
NATIONAL BUREAU OF ECONOMIC RESEARCH 1050 Massachusetts Avenue
Cambridge, MA 02138 \\ August 2004
}

The views expressed herein are those of the author(s) and not necessarily those of the National Bureau of Economic Research.

C2004 by Randall Morck, Daniel Wolfenzon, and Bernard Yeung. All rights reserved. Short sections of text, not to exceed two paragraphs, may be quoted without explicit permission provided that full credit, including (C) notice, is given to the source. 
Corporate Governance, Economic Entrenchment and Growth

Randall Morck, Daniel Wolfenzon, and Bernard Yeung

NBER Working Paper No. 10692

August 2004

JEL No. G0, O1

\begin{abstract}
Around the world, large corporations usually have controlling owners, who are usually very wealthy families. Outside the U.S. and the U.K., pyramidal control structures, cross shareholding and super voting rights are common. Using these devices, a family can control corporations without making a commensurate capital investment. In many countries, such families end up controlling considerable proportions of their countries", economies. Three points emerge. First, at the firm level, these ownership structures vest dominant control rights with families who often have little real capital invested - creating agency and entrenchment problem simultaneously. In addition, controlling shareholders can divert corporate resources for private benefits using transactions within the pyramidal group. The result is a poor utilization of resources. At the economy level, extensive control of corporate assets by a few families distorts capital allocation and reduces the rate of innovation. The result is an economy-wide misallocation of resources, and slower economic growth. Second, political influence is plausibly related to what one controls, rather than what one owns. The controlling owners of pyramids thus have greatly amplified political influence relative to their actual wealth. They appear to influence the development of both public policy, such as property rights protection and enforcement, and institutions like capital markets. We denote this phenomenon economic entrenchment. Third, we conceive of a relationship between the distribution of corporate control and institutional development that generates and preserves economic entrenchment as one equilibrium; but not the only one. Based on the literature, we identify key determinants of economic entrenchment. We also identify many gaps where further work exploring the political economy importance of the distribution of corporate control is needed.
\end{abstract}

$\begin{array}{lll}\text { Randall Morck } & \text { Daniel Wolfenzon } & \text { Bernard Yeung } \\ \text { School of Business } & \text { Stern School of Business } & \text { Stern School of Business } \\ \text { University of Alberta } & \text { New York University } & \text { New York University } \\ \text { Edmonton, Alberta } & \text { 44 West } 4^{\text {th }} \text { Street } & \text { 44 West } \text { th }^{\text {Street }} \\ \text { CANADA T6G2R6 } & \text { New York, NY 10012 } & \text { New York, NY 10012 } \\ \text { and NBER } & \text { dwolfenz@stern.nyu.edu } & \text { byeung@stern.nyu.edu }\end{array}$

randall.morck@ualberta.ca 


\begin{abstract}
Around the world, large corporations usually have controlling owners, who are usually very wealthy families. Outside the U.S. and the U.K., pyramidal control structures, cross shareholding and super voting rights are common. Using these devices, a family can control corporations without making a commensurate capital investment. In many countries, such families end up controlling considerable proportions of their countries' economies. Three points emerge. First, at the firm level, these ownership structures vest dominant control rights with families who often have little real capital invested - creating agency and entrenchment problem simultaneously. In addition, controlling shareholders can divert corporate resources for private benefits using transactions within the pyramidal group. The result is a poor utilization of resources. At the economy level, extensive control of corporate assets by a few families distorts capital allocation and reduces the rate of innovation. The result is an economy-wide misallocation of resources, and slower economic growth. Second, political influence is plausibly related to what one controls, rather than what one owns. The controlling owners of pyramids thus have greatly amplified political influence relative to their actual wealth. They appear to influence the development of both public policy, such as property rights protection and enforcement, and institutions like capital markets. We denote this phenomenon economic entrenchment. Third, we conceive of a relationship between the distribution of corporate control and institutional development that generates and preserves economic entrenchment as one equilibrium; but not the only one. Based on the literature, we identify key determinants of economic entrenchment. We also identify many gaps where further work exploring the political economy importance of the distribution of corporate control is needed.
\end{abstract}

\title{
I. Introduction
}

A growing body of work indicates that economic growth depends on the distribution of control over capital assets. Two vast literatures, already surveyed in the Journal of Economic Literature, are relevant as points of departure. The first, reviewed by Aghion, Caroli, and Garcia-Penalosa (1999), discusses reasons why economic inequality might impede growth. The second, surveyed by Levine (1997), discusses the functional role of capital markets in stimulating growth. We build on these insightful contributions by reviewing recent research that shows how the distribution of corporate control and the workings of capital markets are related, and how their interactions affect economic growth.

For this purpose, the key insight in Aghion et al. (1999, p. 1621) is that perfect capital markets make wealth distribution irrelevant by allocating capital to each investment opportunity until its marginal return equals the market clearing equilibrium interest rate. However, when capital markets are imperfect, inequality reduces investment opportunities, worsens borrowers' incentives, and generates macro-economic volatility. Simple capital market frictions can lead the wealthy to invest more than is the first best optimal, while the impecunious invest less. Assuming diminishing rates of return, redistributing wealth from the rich to the poor raises total output. Such a redistribution, by fostering growth, also creates further investment opportunities for rich and poor alike. Moral hazard problems associated with borrowing are also a feature of imperfect capital markets. If wealth redistribution from rich to poor lessens the overall use of borrowing in the economy, these moral hazard problems ease, raising overall production and reducing the cost of debt financing on the margin (Aghion et al. p. 1626).

Levine (1997) surveys the second literature, on the functions of capital markets in economic growth - the organization of information acquisition, allocation of resources, 
monitoring of managers, and exercise of corporate control. To economize on information acquisition costs, financial intermediaries emerge that specialize in information acquisition, as in Diamond (1984) and Boyd and Presecott (1986). If financial markets are large and liquid enough, and if investors' property rights are sufficiently well protected, individuals expend resources to acquire information and conduct profitable informed risk arbitrage, as modeled by Grossman and Stiglitz (1980) and Shleifer and Vishny (1997), and this trading capitalizes information into stock prices (Morck, Yeung, and Yu (2000)). Roll (1988) argues that this mechanism is especially important for the timely updating of stock prices with new firm-specific information. Stock prices that closely track fundamental values aid external financiers and corporate insiders in capital allocation decisions, simplify monitoring, and facilitate the design of credible incentive contracts that induce managers to keep faith with outside investors and maximize firm value.

These two literatures converge on a central theme: economic growth requires that savings be directed into value creating investments. Rajan and Zingales (2003), Durnev, Morck, and Yeung $(2000,2004)$, and others argue that capital markets are inimitably, though certainly not perfectly, effective in this regard. This is because, by creating incentives for self-interested investors to gather and process information, as well as to monitor and control corporate managers, capital markets generate conditions amenable to efficient capital investment decisions. Directors of corporations needing outside capital must submit to this analysis, monitoring, and control by outside investors. When official regulations, laws, and enforcement make outside investors sufficiently confident of their ability to undertake these tasks, outside investors hold equity. Pooling their capital under the management of institutional investors allows small investors to attain economies of scale in accomplishing these tasks. The resulting efficient financial market directs capital to its highest value uses - a situation Tobin (1982) defines as functional form stock market efficiency. Note that functional form efficiency differs from the standard usage of the term market efficiency in the finance literature, which describes a situation where investors cannot obtain abnormal returns after transactions costs. The two concepts are related, but not identical.

Economists have little difficulty listing fracture points where actual capital markets fail to satisfy functional form efficiency. The literature we survey below argues that the functional efficiency of capital markets depends on the distribution of corporate control in an economy. In particular, this literature views economic growth as critically dependent on institutions that restrain entrenched elites, who could otherwise come to dominate the capital investment decisions of an economy. This literature has its recent roots in corporate finance, perhaps because the extreme concentration of corporate control rights in the hands of tiny elites observed in many countries raises concerns about corporate governance in those economies. The corporate finance literature also considers entrenched management to be a corporate governance issue at the firm level in ways that are helpful in understanding entrenched control in general.

Our starting point is a curious empirical observation reported by Morck, Stangeland and Yeung (2000). These authors divide up the world's US dollar billionaires into two categories self made billionaires and billionaire who inherited their wealth - and sum up the wealth owned by each category of billionaires in each country. Unsurprisingly, they find that a country's per capita GDP grows faster if its self-made billionaire wealth is larger as a fraction of GDP. What is surprising is their result that per capita GDP growth is slower in countries where inherited billionaire wealth is larger as a fraction of GDP. 
The literature we review below points to a set of possible explanations. These explanations involve wealthy individuals who magnify their already substantial wealth into control over multiple corporations worth vastly more. La Porta et al. (1999) show that this magnification is most commonly achieved using control pyramids: structures in which a family firm controls several listed companies, each of which controls yet more listed companies, each of which controls yet more listed companies, and so on. Family members are usually placed as executives of key firms throughout the structure. Other less common devices also used to this end include superior voting shares and crossholdings. Superior voting shares, distinct classes of stock with many more votes per share than ordinary common stock, allow insiders to control the majority of votes in shareholder meetings even though they own only a small fraction of the firm's equity. Crossholdings are structures in which firms own blocks of each others' stocks. Since insiders vote these blocks, they exercise control beyond their actual ownership. These sorts of structures can let a few wealthy families control in the greater part of a country's large corporate sector. They also leave the structure typical of large U.S. firms - stand alone firms with diffuse ownership and professional management - the rarest of curiosities in most of the rest of the world.

This concentrated control can lead to corporate governance concerns - agency and entrenchment problems. Entrusting the governance of huge slices of a country's corporate sector to a tiny collection of elites can bias capital allocation to advantage those elites, and can also reduce the pace of innovation. These effects, in turn, impede the development of capital markets, further distort capital allocation, and more generally retard growth. In addition, to preserve their privileged positions under the status quo, the controlling elites arguably use their political connections to stymie the institutional development of capital markets and to erect a variety of entry barriers.

Such an outcome is a suboptimal political economy equilibrium, which we dub economic entrenchment. While wealthy established families are probably important to economic entrenchment in many countries, the problem is probably not restricted to countries whose corporate sectors are controlled by small cliques of extremely wealthy families. Other sorts of elites can also become entrenched in positions of control over corporate assets and behave much like elite families, generating a similar outcome - functionally inefficient capital markets, high barriers to entry and a slow pace of innovation.

The layout of this article is as follows. First, we motivate this survey by discussing some empirical findings that suggest a link between economic growth and, not the concentration of wealth per se, but the "hands" in which control over corporate assets is concentrated. Second, we review the literature on corporate ownership, pyramidal groups, and family control. This literature shows that many economies entrust the governance of large parts of their corporate sectors to tiny elites of extremely wealthy families. Third, we discuss issues associated with such concentrated corporate governance, and how these might affect economic performance. Fourth, we evaluate the linkage between concentrated corporate control on the one hand and overall capital allocation, capital market development, creative destruction, and macroeconomic growth on the other. Fifth, we discuss entrenchment as a political economy problem. We discuss the determinants of economic entrenchment, which include investment opportunities, societal tradition, and initial endowments. Also, we examine the relationship between economic entrenchment and openness. Finally, we attempt to distill some general conclusions out of the above. 


\section{Inherited Wealth and Growth - A Preliminary Reading}

Our starting point is a curious observation by Morck, Stangeland, and Yeung (2000). Using Forbes' listing of the one thousand wealthiest individuals in the world for 1993, and the brief biographies accompanying each, they distinguish new money billionaires, entrepreneurs who made their billions themselves, from old money billionaires, who inherited their wealth. They gauge the importance of each type of billionaire in a given country by the sum of the wealth of that type of billionaire as a fraction of the country's GDP. When they regress real per capita GDP growth from 1994 to 1996 on these measures, controlling for initial per capita GDP, physical capital accumulation, and education levels, they find new money billionaire wealth to be associated with faster economic growth, but old money billionaire wealth to be associated with slower growth. That is, in standard growth theory regressions of the sort used by Mankiw (1995), they report a highly significant relationship between growth and variables plausibly reflecting the distribution of control over an economy's capital assets.

Table 1 The Cross-Country Relationship Between Growth in Real Per Capita GDP and Capital Ownership, Controlling for Current per Capita Income, Capital Investment Rate, and Level of Education

\begin{tabular}{|c|c|c|c|c|c|c|c|c|}
\hline & 1.1 & 1.2 & 1.3 & 1.4 & 1.5 & 1.6 & 1.7 & 1.8 \\
\hline Intercept & $\begin{array}{c}1.43 \\
(0.32)\end{array}$ & $\begin{array}{c}1.58 \\
(0.30)\end{array}$ & $\begin{array}{c}1.59 \\
(0.27)\end{array}$ & $\begin{array}{c}1.65 \\
(0.28)\end{array}$ & $\begin{array}{l}1.75 \\
(0.22)\end{array}$ & $\begin{array}{c}1.73 \\
(0.26)\end{array}$ & $\begin{array}{c}1.86 \\
(0.20)\end{array}$ & $\begin{array}{c}1.78 \\
(0.25)\end{array}$ \\
\hline $\begin{array}{l}\text { Log of per capita } \\
\text { GDP: } \ln (Y / L)\end{array}$ & $\begin{array}{l}\mathbf{- 1 . 7 6} \\
(0.00)\end{array}$ & $\begin{array}{l}\mathbf{- 1 . 7 7} \\
(0.00)\end{array}$ & $\begin{array}{l}-1.80 \\
(0.00)\end{array}$ & $\begin{array}{l}-1.79 \\
(0.00)\end{array}$ & $\begin{array}{l}-1.54 \\
(0.00)\end{array}$ & $\begin{array}{l}\mathbf{- 1 . 6 6} \\
(0.00)\end{array}$ & $\begin{array}{l}-1.62 \\
(0.00)\end{array}$ & $\begin{array}{l}\mathbf{- 1 . 6 9} \\
(0.00)\end{array}$ \\
\hline $\begin{array}{r}\text { Capital Accumulation } \\
\text { Rate: } I / K\end{array}$ & $\begin{array}{c}\mathbf{0 . 2 1} \\
(0.00)\end{array}$ & $\begin{array}{c}\mathbf{0 . 2 2} \\
(0.00)\end{array}$ & $\begin{array}{c}\mathbf{0 . 2 1} \\
(0.00)\end{array}$ & $\begin{array}{c}\mathbf{0 . 2 1} \\
(0.00)\end{array}$ & $\begin{array}{c}\mathbf{0 . 1 7} \\
(0.00)\end{array}$ & $\begin{array}{c}\mathbf{0 . 2 0} \\
(0.00)\end{array}$ & $\begin{array}{c}\mathbf{0 . 1 8} \\
(0.00)\end{array}$ & $\begin{array}{c}\mathbf{0 . 2 0} \\
(0.00)\end{array}$ \\
\hline $\begin{array}{c}\text { Average Total Years } \\
\text { of Education: } \ln (E)\end{array}$ & $\begin{array}{l}00.23 \\
(0.27)\end{array}$ & $\begin{array}{l}00.20 \\
(0.35)\end{array}$ & $\begin{array}{l}00.25 \\
(0.23)\end{array}$ & $\begin{array}{l}00.21 \\
(0.32)\end{array}$ & $\begin{array}{l}00.24 \\
(0.24)\end{array}$ & $\begin{array}{l}00.20 \\
(0.35)\end{array}$ & $\begin{array}{l}00.26 \\
(0.21)\end{array}$ & $\begin{array}{l}00.21 \\
(0.32)\end{array}$ \\
\hline $\begin{array}{r}\text { Business Entrepreneur } \\
\text { Billionaire Wealth Over } \\
\text { GDP: } B / Y\end{array}$ & $\begin{array}{c}\mathbf{0 . 4 4} \\
(0.00)\end{array}$ & $\begin{array}{c}\mathbf{0 . 3 7} \\
(0.00)\end{array}$ & $\begin{array}{c}\mathbf{0 . 4 2} \\
(0.00)\end{array}$ & $\begin{array}{c}\mathbf{0 . 3 7} \\
(0.00)\end{array}$ & $\begin{array}{c}\mathbf{0 . 5 0} \\
(0.00)\end{array}$ & $\begin{array}{c}\mathbf{0 . 3 8} \\
(0.00)\end{array}$ & $\begin{array}{c}\mathbf{0 . 4 5} \\
(0.00)\end{array}$ & $\begin{array}{c}\mathbf{0 . 3 7} \\
(0.00)\end{array}$ \\
\hline $\begin{array}{r}\text { Heir Billionaire Wealth } \\
\text { Over GDP: } H / Y\end{array}$ & $\begin{array}{l}\mathbf{- 0 . 2 9} \\
(0.03)\end{array}$ & $\begin{array}{l}\mathbf{- 0 . 1 7} \\
(0.10)\end{array}$ & $\begin{array}{l}\mathbf{- 0 . 2 7} \\
(0.03)\end{array}$ & $\begin{array}{l}\mathbf{- 0 . 1 6} \\
(0.09)\end{array}$ & $\begin{array}{l}\mathbf{- 0 . 4 1} \\
(0.01)\end{array}$ & $\begin{array}{l}\mathbf{- 0 . 1 9} \\
(0.09)\end{array}$ & $\begin{array}{l}\mathbf{- 0 . 3 3} \\
(0.01)\end{array}$ & $\begin{array}{l}\mathbf{- 0 . 1 7} \\
(0.08)\end{array}$ \\
\hline $\begin{array}{r}\text { Definition of 'heir' a } \\
\text { R squared }\end{array}$ & $\begin{array}{c}H_{1} \\
0.519\end{array}$ & $\begin{array}{c}H_{2} \\
0.488\end{array}$ & $\begin{array}{c}H_{3} \\
0.531\end{array}$ & $\begin{array}{c}H_{4} \\
0.489\end{array}$ & $\begin{array}{c}H_{5} \\
0.545\end{array}$ & $\begin{array}{c}H_{6} \\
0.491\end{array}$ & $\begin{array}{c}H_{7} \\
0.536\end{array}$ & $\begin{array}{c}H_{8} \\
0.491\end{array}$ \\
\hline
\end{tabular}

Note: Numbers in parenthesis are two tailed t-test probability levels for rejecting a zero coefficient. Coefficients in boldface are statistically significant at $90 \%$ confidence or more. Sample of 39 countries consists of the countries listed in Table 1 minus the U.K. and U.S. See Morck et al. (2000), Table 2 for further details.

${ }^{\text {a }} H_{l}$ includes only the wealth of billionaires known positively to be heirs, politicians or politicians' relations. $H_{2}$ also includes the wealth of billionaires who are probably heirs. $H_{3}$ includes $H_{1}$ plus fortunes jointly controlled by a founder and his heirs. $H_{4}$ includes all the above. $\mathrm{H}_{5}$ through $\mathrm{H}_{8}$ are analogous to $\mathrm{H}, \mathrm{H}_{2}, \mathrm{H}_{3}$ and $\mathrm{H}_{4}$ but do not include politician billionaires and their relations.

Table 1 recapitulates these results. The alternative specifications shown treat wealth that is not unambiguously controlled by either a founder or an heir differently. $H_{1}$ includes only the wealth of billionaires who are unambiguously heirs, politicians or politicians' relations. $\mathrm{H}_{2}$ also includes the wealth of billionaires who are probably heirs. $H_{3}$ includes $H_{1}$ plus fortunes jointly controlled by a founder and his heirs. $H_{4}$ includes all the above. $H_{5}$ through $H_{8}$ are analogous to 
$\mathrm{H}, \mathrm{H}_{2}, \mathrm{H}_{3}$ and $\mathrm{H}_{4}$ but do not include politician billionaires and their relations. The positive coefficients on new money billionaire wealth and the negative one on old money billionaire wealth remain highly significant across all the different specifications.

Previous work, surveyed by Aghion et al. (1999) discusses the relationship between general inequality and growth, but Morck et al. (2000) add another twist - inequality involving new money wealth seems different from inequality involving old money wealth. Perhaps economists need to think less about concentration of wealth per se and more about concentration of wealth in whose hands? Why might inequality associated with inherited wealth be fundamentally different from inequality associated with entrepreneurial wealth? To explore this, we must first examine how highly concentrated wealth can translate into even more highly concentrated corporate governance power.

\section{The Ubiquity and Purpose of the Control Pyramid}

The extensive control wealthy families exert over the corporate sectors of most of the world's economies depends on a particular ownership structure, the control pyramid, and other closely related structures. While such structures are commonplace outside of the U.S., they were not well known in the academic literature until highlighted in recent work by La Porta et al. (1999). That research inspired further empirical work confirming that (i) most large corporations around the world have controlling owners, and (ii) controlling owners use pyramidal structures to amass control over not just a single firm, or even just a few firms, but over large groups of corporations.

This section surveys empirical evidence about the structure of corporate control around the world. We first highlight the ubiquity of concentrated family control outside the United States. We then discuss control pyramids in detail and show they allow a very small number of wealthy individuals or families to leverage substantial wealth into control over corporate assets worth vastly more. While this section primarily emphasizes concentrated control over large groups of firms using control pyramids, it also briefly mentions other related structures.

\section{A. Wealthy Families Control Most Companies around the World Corporations have dominant owners}

That large corporations have individuals and families as controlling shareholders contradicts the view of the firm popularly attributed to Berle and Means (1932), which implicitly or explicitly underlies much of modern economics and finance. ${ }^{1}$ In this view, a corporation is widely held, in that its ownership is dispersed across a large number of small public shareholders, and freestanding, in that listed companies generally do not control other listed companies. Since there is no dominant owner, effective control resides in the hand of the management team. In such corporations, corporate governance is about mitigating the divergence of interests, described by Jensen and Meckling (1976), between utility maximizing professional managers and small public shareholders who would like the value of their shares to be maximized.

The modern U.S. economy loosely approximates this archetype. Of course, large blockholders and intercorporate equity holdings occur in the United States. Shleifer and Vishny (1986), Morck et al. (1988), Holderness and Sheehan (1988), Anderson and Reeb (2003b),

\footnotetext{
1 Berle and Means (1932, Ch. 5) actually describe various forms of pyramiding, non-voting shares, and voting trusts. In their sample of the largest 200 firms in the U.S. in 1930, they find that $44 \%$ are widely held (they call them 'management controlled') and $22 \%$ are controlled through a 'legal devise' (i.e., a pyramid). In any case, the finance literature has for the most part taken Berle and Means as demonstrating that large U.S. firms are largely widely held.
} 
Anderson, Mansi and Reeb (2003) and others all find numerous instances of large blockholders, though they are smaller and much less common in large US firms than in most other countries. An important distinction, however, is that block holders in the US seldom control more than one corporation. Thus, the Ford family controls Ford Motors, but not GM, IBM, and 3M as well. Indeed, none of these other companies has any controlling shareholder. In its most recent proxy, $3 \mathrm{M}$ reports that corporate insiders own less than one percent of its stock, and that its largest shareholder is a pension fund, with a stake somewhat above three percent. Morck et al. (1988) show that $3 \mathrm{M}$ is more typical of large US firms than is Ford, and subsequent work confirms this. Indeed, the term "family firm" in the United States is often a synonym for "small firm."

However, elsewhere in the world, the typical large firm has a "controlling owner," usually a wealthy family that controls it as part of a large group of firms. The assumption of freestanding diffusely owned firms, typically justified with a cite to Berle and Means (1932), is therefore of questionable generality. This was first pointed out in studies of corporate governance in Germany and Japan, such as Prowse (1992), Berglof and Perotti (1994) and Edwards and Fischer (1994). In a systematic investigation, La Porta et al. (1999) show that United States style corporate ownership is quite exceptional. In most other countries, even very large firms have controlling shareholders, and these are usually extremely wealthy families.

La Porta et al. (1999) investigate the ownership structures of large corporations in twenty-seven developed economies. Their sample contains the top twenty firms in each country, ranked by market capitalization of common equity at the end of 1995. They also collect information on ten firms of similar size in each country. These are the ten smallest firms in each country with market capitalization of common equity greater than $\$ 500$ million at the end of 1995. They allow for five types of ultimate controlling owners: (1) a family or an individual, (2) the state, (3) a widely held financial institution such as a bank or an insurance company, (4) a widely held corporation, and (5) miscellaneous, an entity such as a cooperative, a voting trust, or a group with no single controlling investor. La Porta et al. (1999) argue that stakes exceeding fifty percent are not necessary to lock in control in most cases. This is because most small shareholders do not vote at annual meetings. Consequently, voting stakes in the ten to twenty percent range are generally sufficient.

They report widely held corporations predominating among large firms only in the United States and United Kingdom. Elsewhere, particularly in countries with poor legal and weak regulatory protection for public shareholders, even the largest corporations usually have controlling shareholders - predominantly wealthy families and the State. Using a twenty percent control threshold, they find that $36 \%$ of large corporations on average are widely held. The distribution shifts further away from widely held firms when the sample is based on a ten percent control threshold, or on a set of smaller firms, or on countries with poorer shareholder rights protection. In a few countries, notably Belgium and Germany, financial institutions exercise extensive voting control over other large publicly traded companies.

Studies subsequent to La Porta et al. (1999) typically expand the number of firms examined and sometimes the number of countries, and tend to confirm the La Porta et al. (1999) findings. Claessens et al. (2000) examine 2,980 publicly traded corporations, including both financial and non-financial firms, in Asian countries including Hong Kong, Indonesia, Japan, South Korea, Malaysia, the Philippines, Singapore, Taiwan (China), and Thailand. Their data are for 1996. Using the existence of a ten percent blockholder to define control, they determine that widely held companies account for less than three percent of the corporate sectors of each of these countries save Japan and Korea, where the figures are $42 \%$ and $14 \%$, respectively. Using a 
twenty percent control threshold, widely held companies are still less than twenty percent of the corporate sectors of these countries, again except in Japan, Korea, and Taiwan (China); where they account for $80 \%, 43 \%$, and $26 \%$ respectively. The high figures for widely held firms in Japan are perhaps misleading, in the sense that most large Japanese firms are organized into keiretsu, groups of firms without controlling shareholders that collectively own control blocks in each other. These firms are thus not really widely held in the sense of US and United Kingdom firms, for public shareholders do not hold a majority of their stock.

Faccio and Lang (2002) ascertain the ultimate controlling shareholder of 5,232 corporations in thirteen Western European countries: Austria, Belgium, Finland, France, Germany, Ireland, Italy, Norway, Portugal, Spain, Sweden, Switzerland, and the UK. Using a twenty percent control threshold, they find $37 \%$ of these companies to be widely-held. This figure is only $14 \%$ when a ten percent threshold control level is used. Moreover, the vast majority of these widely held firms are in the United Kingdom and Ireland $-63 \%$ and $62 \%$, respectively, of firms in those countries are widely held.

Barca and Becht (2001) survey the ownership structures of typical large companies across Europe and in the United States. They also find that the widely held firm is not representative for Europe. They report (p. 19) that the median largest shareholder in a typical large corporation votes a 52\% stake in Austria, 56\% in Belgium, 57\% in Germany, 35\% in Spain, 20\% in France, 55\% in Italy, 44\% in the Netherlands, and 35\% in Sweden. They contrast this with a $10 \%$ median stake in the United Kingdom and a 5\% and 9\% median stake among NYSE and NASDAQ firms, respectively, in the United States.

\section{Concentrated control of corporation is in the hand of wealthy families}

As noted above, firms around the world have dominant shareholders. It turns out that these dominant shareholders are generally wealthy families. La Porta et al. (1999) report that among the largest firms and using a 20\% control threshold, $30 \%$ of the firms are family-controlled. This figure increases when a sample of smaller firms is used, or when the threshold of control is $10 \%$.

Claessens et al. (2000, Table 6, p. 103) measure the incidence of family control in Asian countries. Using a ten percent threshold, $65 \%$ of Hong Kong firms are family controlled. The comparable figures are $69 \%$ in Indonesia, $13 \%$ in Japan, $68 \%$ in Korea, 58\% in Malaysia, $42 \%$ in the Philippines, 52\% in Singapore, $66 \%$ in Taiwan (China), and 57\% in Thailand. Using a twenty percent threshold to infer control, the corresponding figures are $67 \%$ in Hong Kong, $72 \%$ in Indonesia, $10 \%$ in Japan, 48\% in Korea, 67\% in Malaysia, 45\% in the Philippines, 55\% in Singapore, $48 \%$ in Taiwan (China), and $62 \%$ in Thailand.

Faccio and Lang (2002) report that family control predominates in eleven continental European countries: Austria, Belgium, Finland, France, Germany, Italy, Norway, Portugal, Spain, Sweden, and Switzerland. The incidence of family control, defined as at least twenty percent voting control, is lowest in Norway (39\%) and highest in France and Germany (65\%). In all the other countries they study, family control is at least $46 \%$.

All these studies confirm the basic observation of La Porta et al. (1999), that diffuse corporate ownership of the sort generally associated with Berle and Means (1932) for the US is highly exceptional. Outside of the US and UK, large firms usually have ultimate controlling owners, and these are usually very wealthy families. Table 2 summarizes the findings of these various studies, and clearly displays the rarity of widely held firms and the ubiquity of family control. Although Table 2 contains a wealth of data, further work involving additional countries and clarifying the determinants of these differences would be very useful. 


\section{Table 2 - Widely Held Firms versus Family Controlled Firms as Percent of Large Corporations in Various Countries ${ }^{\mathrm{a}}$}

\begin{tabular}{|c|c|c|c|c|c|}
\hline \multirow[b]{2}{*}{ Country } & \multicolumn{2}{|c|}{$\begin{array}{c}\text { Control inferred at } \\
10 \% b\end{array}$} & \multicolumn{2}{|c|}{$\begin{array}{c}\text { Control inferred at } \\
20 \%\end{array}$} & \multirow[t]{2}{*}{ Source } \\
\hline & $\begin{array}{l}\text { Widely } \\
\text { held }\end{array}$ & $\begin{array}{l}\text { Family } \\
\text { control }\end{array}$ & $\begin{array}{l}\text { Widely } \\
\text { held }\end{array}$ & $\begin{array}{l}\text { Family } \\
\text { control }\end{array}$ & \\
\hline Argentina & 0 & 65 & 0 & 65 & La Porta et al. (1999, Tables 2 \& 3) \\
\hline Australia & 55 & 10 & 65 & 5 & La Porta et al. (1999, Tables 2 \& 3) \\
\hline Austria & 5 & 15 & 5 & 15 & La Porta et al. (1999, Tables 2 \& 3) \\
\hline Belgium & 0 & 50 & 5 & 50 & La Porta et al. (1999, Tables 2 \& 3) \\
\hline \multirow[t]{2}{*}{ Canada } & 50 & 30 & 60 & 25 & La Porta et al. (1999, Tables 2 \& 3) \\
\hline & 17.54 & 46.67 & 36.24 & 26.18 & Attig, Gadhoum, Lang (2003) \\
\hline Denmark & 10 & 35 & 40 & 35 & La Porta et al. (1999, Tables 2 \& 3) \\
\hline Finland & 15 & 10 & 35 & 10 & La Porta et al. (1999, Tables 2 \& 3) \\
\hline \multirow[t]{2}{*}{ France } & 30 & 20 & 60 & 20 & La Porta et al. (1999, Tables 2 \& 3) \\
\hline & 8.92 & 70.44 & 17.79 & 64.83 & Faccio, Lang $(2002)^{\mathrm{a}}$ \\
\hline \multirow[t]{2}{*}{ Germany } & 35 & 10 & 50 & 10 & La Porta et al. (1999, Tables 2 \& 3) \\
\hline & 5.61 & 71.64 & 14.02 & 64.62 & Faccio, Lang (2002) \\
\hline Greece & 5 & 65 & 10 & 50 & La Porta et al. (1999, Tables 2 \& 3) \\
\hline \multirow[t]{2}{*}{ Hong Kong } & 10 & 70 & 10 & 70 & La Porta et al. (1999, Tables 2 \& 3) \\
\hline & 0.6 & 64.7 & 7 & 66.7 & Claessens, Djankov, Lang (2000) \\
\hline Indonesia & 0.6 & 68.6 & 5.1 & 71.5 & Claessens, Djankov, Lang (2000) \\
\hline Ireland & 45 & 15 & 65 & 10 & La Porta et al. (1999, Tables 2 \& 3) \\
\hline Israel & 5 & 50 & 5 & 50 & La Porta et al. (1999, Tables 2 \& 3) \\
\hline \multirow[t]{2}{*}{ Italy } & 15 & 20 & 20 & 15 & La Porta et al. (1999, Tables 2 \& 3) \\
\hline & 7.83 & 64.87 & 15.86 & 59.61 & Faccio, Lang (2002) \\
\hline \multirow[t]{2}{*}{ Japan } & 50 & 10 & 90 & 5 & La Porta et al. (1999, Tables 2 \& 3) \\
\hline & 42 & 13.1 & 79.8 & 9.7 & Claessens, Djankov, Lang (2000) \\
\hline \multirow[t]{2}{*}{ Korea } & 40 & 35 & 55 & 20 & La Porta et al. (1999, Tables 2 \& 3) \\
\hline & 14.3 & 67.9 & 43.2 & 48.4 & Claessens, Djankov, Lang (2000) \\
\hline Malaysia & 1 & 57.5 & 10.3 & 67.2 & Claessens, Djankov, Lang (2000) \\
\hline Mexico & 0 & 100 & 0 & 100 & La Porta et al. (1999, Tables 2 \& 3) \\
\hline Netherlands & 30 & 20 & 30 & 20 & La Porta et al. (1999, Tables 2 \& 3) \\
\hline New Zealand & 5 & 45 & 30 & 25 & La Porta et al. (1999, Tables 2 \& 3) \\
\hline Norway & 5 & 25 & 25 & 25 & La Porta et al. (1999, Tables 2 \& 3) \\
\hline Philippines & 1.7 & 42.1 & 19.2 & 44.6 & Claessens, Djankov, Lang (2000) \\
\hline Portugal & 0 & 50 & 10 & 45 & La Porta et al. (1999, Tables 2 \& 3) \\
\hline \multirow[t]{2}{*}{ Singapore } & 5 & 45 & 15 & 30 & La Porta et al. (1999, Tables 2 \& 3) \\
\hline & 1.4 & 52 & 5.4 & 55.4 & Claessens, Djankov, Lang (2000) \\
\hline \multirow[t]{2}{*}{ Spain } & 15 & 25 & 35 & 15 & La Porta et al. (1999, Tables 2 \& 3) \\
\hline & 12.74 & 67.33 & 28.06 & 55.79 & Faccio, Lang (2002) \\
\hline Sweden & 0 & 55 & 25 & 45 & La Porta et al. (1999, Tables 2 \& 3) \\
\hline Switzerland & 50 & 40 & 60 & 30 & La Porta et al. (1999, Tables 2 \& 3) \\
\hline Taiwan (China) & 2.9 & 65.6 & 26.2 & 48.2 & Claessens, Djankov, Lang (2000) \\
\hline Thailand & 2.2 & 56.5 & 6.6 & 61.6 & Claessens, Djankov, Lang (2000) \\
\hline United & 90 & 5 & 100 & 0 & La Porta et al. (1999, Tables 2 \& 3) \\
\hline Kingdom & 27.06 & 33.75 & 69.08 & 19.88 & Faccio, Lang (2002) \\
\hline \multirow[t]{2}{*}{ United States } & 80 & 20 & 80 & 20 & La Porta et al. (1999, Tables 2 \& 3) \\
\hline & 38.95 & 23.37 & 69.26 & 6.13 & Attig, Gadhoum, Lang (2003) \\
\hline
\end{tabular}

a. The figures from La Porta el at (1999) are for the 20 largest publicly listed firms. The Attig, Gadhoum and Lang (2003) sample is comprised of the 1121 firms in the Toronto Stock Exchange, for which they could find ownership data. Faccio and Lang (2002) and Claessens, Djankov, and Lang (2000) also construct samples of all publicly traded firm for which ownership information is available.

b. The published version of Faccio and Lang (2002) does not have tables with the $10 \%$ cutoff. We report statistics in their earlier unpublished draft. 
Figure 1. A Stylized Control Pyramid

A family firm controls a first tier of firms with dominant voting stakes, in this case greater than fifty percent. Each first tier firm controls several second tier firms, each of which controls yet more firms. The overall effect is to extend the family's control to encompass assets worth substantially more than its actual wealth.

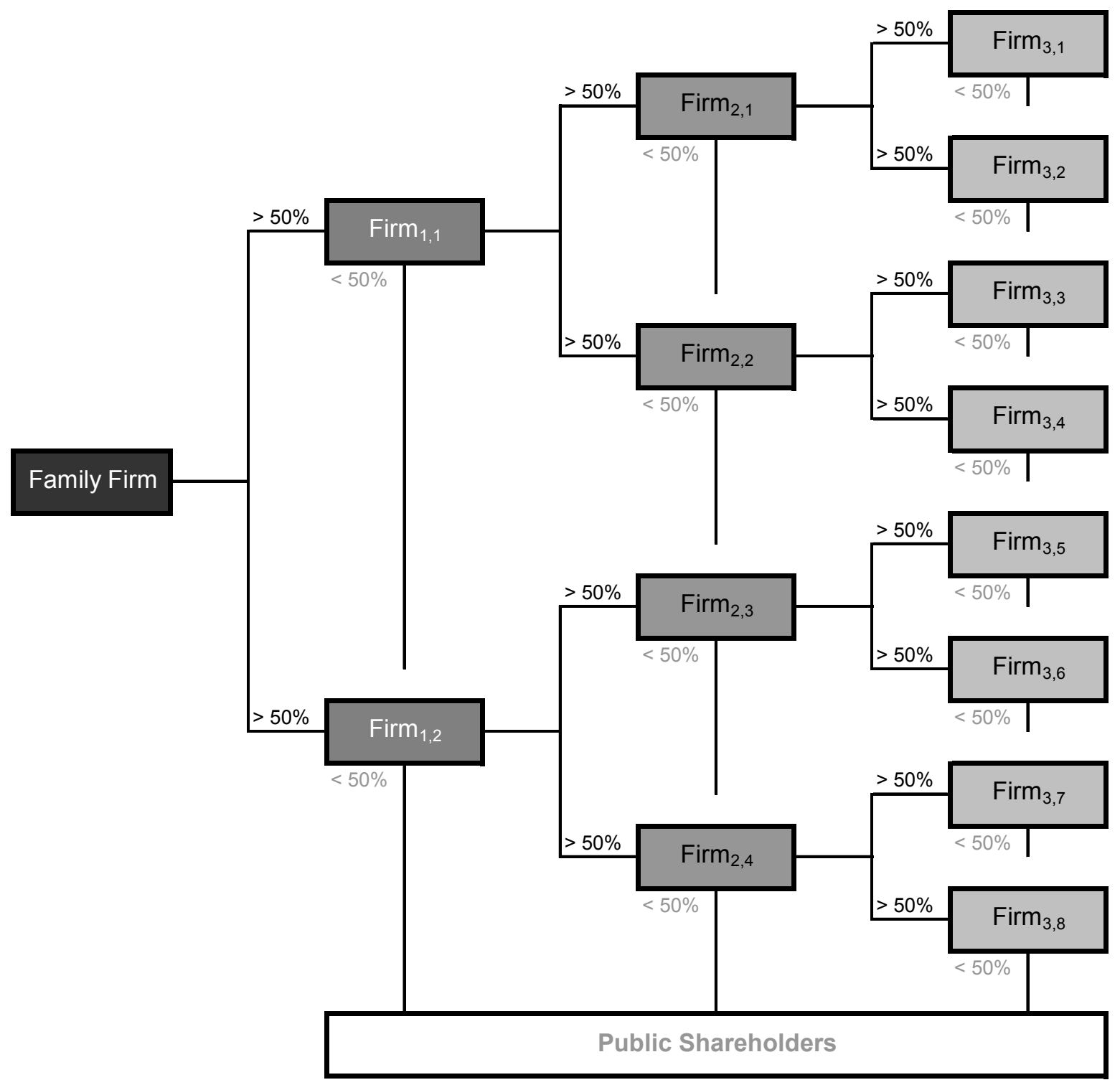

\section{B. The Use of Control Pyramids}

The previous subsections presented evidence that large corporations throughout most of the world are not widely held and more often than not are controlled by very wealthy families. This subsection outlines how these families achieve such concentrated corporate control. The most important mechanism families use is the control pyramids, sometimes augmented by multiple voting shares and crossholdings. Control pyramids let these families control not just one large firm, but a many large firms collectively worth substantially more than the family's actual wealth. 
Figure 1 illustrates a simplified control pyramid. A family firm, which is a holding company in this simplified example, holds a majority stake, fifty percent plus one vote, in each of a first tier of firms, in this case Firm ${ }_{1,1}$ and Firm ${ }_{1,2}$. The remaining fifty percent minus one vote stakes in each are held by small public shareholders. Each of the first tier firms then holds fifty percent plus one vote in a set of second tier firms. In this case, Firm 1,1 holds control blocks in Firm 2,1 and Firm 2,2 while Firm 1,2 holds control blocks in Firm F,3 $_{2,3}$ and Firm 2,4 . Again, the remaining fifty percent, less one vote, in each tier two firm is held by public investors. Each second tier firm then controls a set of third tier firms, and so on, always with public shareholders holding the remaining stakes.

Suppose each firm in Figure 1 is worth one billion dollars. The control pyramid lets the family, through its one billion dollar family firm, control fourteen other firms, also each worth one billion dollars. Ignoring double counting, the family leverages one billion dollars of investment into fifteen billion dollars of control. There is double counting in this tally since, in this simplified example, the assets of the higher tier firms are shares of lower tier firms. But even if only the third tier firms contain actual physical assets, the family has, at a minimum, leveraged one billion dollars of family wealth into control over eight billion dollars of real corporate assets. Contrast this with creating eight freestanding one billion dollar firms, or, a single eight billion dollar firm. In either case, the family contributes only one-eighth of the equity and controls only $12.5 \%$ of the votes. In contrast, the pyramidal structure in Figure 1 lets the family retain absolute control of the eight firms in the third layer of the pyramid, but hold only a $12.5 \%$ cash flow stake $[(50 \%)(50 \%)(50 \%)=12.5 \%]$.

To see this more generally, take the chain of ownership from the family apex to any firm in the third layer, say firm Firm 3,1 . Suppose the family holds $\alpha_{1,1}^{0}$ of Firm 1,1 which holds $\alpha_{2,1}^{1,1}$ of Firm $_{2,1}$ which, in turn, holds $\alpha_{3,1}^{2,1}$ of Firm 3,1 . The superscript, e.g., $(1,1)$, indicates first the "controlling" firm's level in the pyramid and its identity index at the level. The subscript, e.g., $(2,1)$, indicates the "controlled" firm's level in the pyramid and its identity index at that level. If, at each link in the chain of control, the direct stake is sufficiently large to control the next firm, the family effectively controls Firm ${ }_{3,1}$ while holding stock that entitles it to only $\alpha_{1,1}^{0} \times \alpha_{2,1}^{1,1} \times \alpha_{3,1}^{2,1}$ of the firm's dividends. This formula can be straightforwardly expanded when there are more layers connecting the family with the firm. Since the $\alpha$ 's are all less than one, this product can be a very small number. Nonetheless, the family controls every firm in the chain of firms connecting the family firm to Firm ${ }_{3,1}$ and so controls that firm too. Ultimately, the family can control many firms in this way even though its actual investment in each is small.

Actual pyramids are more complicated than Figure 1. Firms can have varying numbers of subsidiaries, and some firms in intermediate tiers of the pyramid can engage in actual production activities. Privately held firms can be interspersed with publicly traded firms. Firms also need not be neatly arranged in successive tiers. Firms in lower tiers may have crossshareholdings. That is, they may own shares in firms in their own tiers or in upper tiers.

Cross shareholdings, differential voting shares, and public shareholders' low participation rates in corporate votes generally allow control through chains of even smaller $\alpha^{\prime} s$, resulting in even more extreme divergence of ownership from control with each additional layer. Since family controlled boards vote cross holdings, these augment direct family voting power. Supervoting shares also allow control with smaller values of $\alpha$. Returning to our example in Figure 1, if super-voting shares let the family exercise control with ten percent at each layer, rather than fifty percent, the family's stake in the third layer would be $(10 \%)(10 \%)(10 \%)=0.1 \%$ instead of 
the $12.5 \%$ calculated above. Since voting rates by public shareholders are generally quite low, a ten to twenty percent stake is usually sufficient to control board elections, so the last calculation is often relevant even in the absence of multiple voting shares.

By way of illustration, Morck et al. (2000) follow an actual chain of control through the apparently quite well-governed pyramid of the Canadian billionaire heirs Edward and Peter Bronfman using data from Statistics Canada's Directory of Intercorporate Ownership for 1998. The brothers "own Broncorp Inc., which controls HIL Corp. with a 19.6\% equity stake. HIL owns $97 \%$ of Edper Resources, which owns $60 \%$ of Brascan Holdings, which owns a $5.1 \%$ stake in Brascan, which owns $49.9 \%$ of Braspower Holdings, which owns $49.3 \%$ of Great Lakes Power Inc, which owns $100 \%$ of First Toronto Investments, which owns $25 \%$ of Trilon Holdings, which owns $64.5 \%$ of Trilon Financial, which owns $41.4 \%$ of Gentra, which owns $31.9 \%$ of Imperial Windsor Group. [The brothers'] actual equity stake in Imperial Windsor works out to $0.03 \%$, yet they have full control of it, and of all the other firms in the pyramid above and beside it. This is because they either own a dominant block of the stock at each stage, or wield sufficient votes to appoint the board via multiple-voting shares, intercorporate crossholdings, or other arrangements that reduce the minimum size of a control stake. This branch of the Bronfman family controls several hundred firms in this way."

Figure 2. The ABB Control Pyramid of the Swedish Wallenberg Family Ownership stakes are represented with $C$ and voting stakes with $V$. Ultimate control is assigned to the Wallenberg family through a chain of stakes of at least $20 \%$

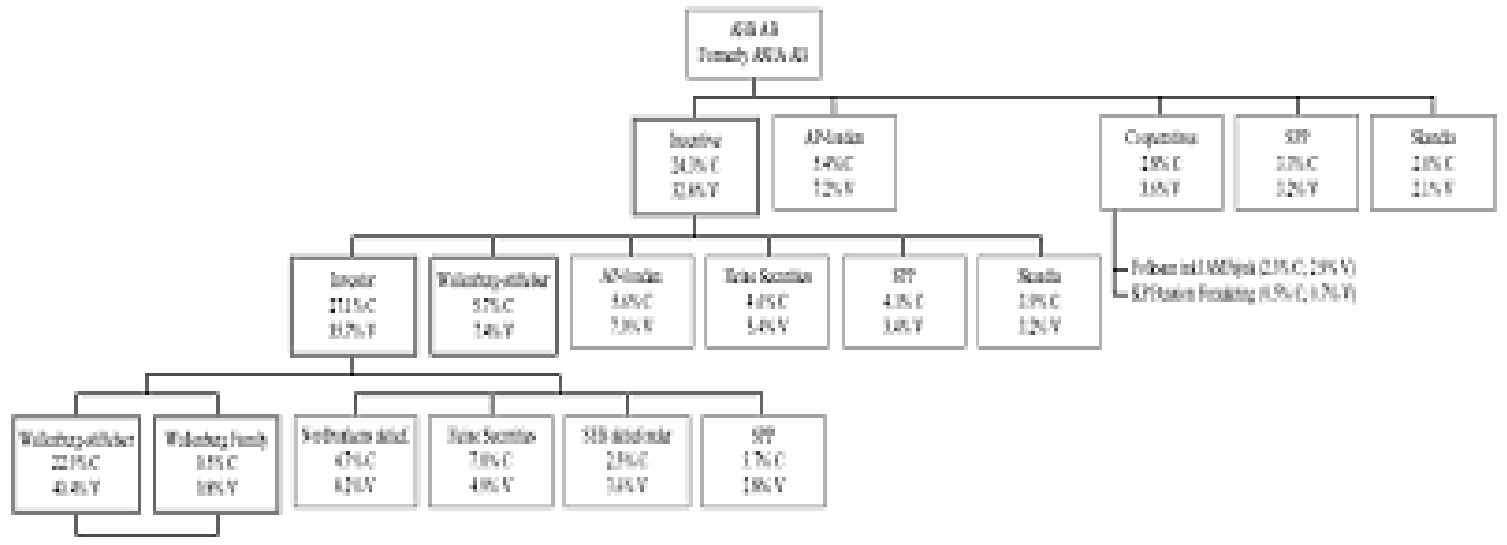

Source: La Porta et al. (1999)

The Bronfman group is too large to represent legibly in a single diagram, however the point can be made with a smaller pyramidal group. La Porta et al. (1999) follow a chain of control by which ABB, Sweden's fourth largest firm by market capitalization, is controlled via a $32.8 \%$ stake held by Incentive, Sweden's $17^{\text {th }}$ largest firm. Incentive, in turn, is controlled via a $43.1 \%$ stake held by the Wallenberg Group, which is controlled by Investor, Sweden's fifth largest firm, through a voting arrangement that gives it control over $35.7 \%$ of the Wallenberg Group's 43.1\% stake in Incentive. Investor is the Wallenberg's family run closed end fund and serves as the apex firm for their family control pyramid. In this way, a sharp divergence between control rights and cash flow rights characterizes many Swedish firms: For example, the Wallenbergs have voting control over ABB, but actually have a cash flow rights stake of only about 5\%. La Porta et al. (1999, Figure 8) describe the ABB pyramidal structure. 
As we explained above, a control pyramid allows a wealthy family or individual to control a large number of firms with relatively limited wealth. Pyramids permit this by creating large deviations between voting rights and cash flow rights; allowing control over many firms with a small cash flow stake in each.

Controlling families effectuate control by placing family members in executive positions in key firms throughout a pyramidal group. La Porta et al. (1999) show that this frequently gives controlling families direct executive decision-making power, as well as control via pyramids. In sixty-nine percent of their sample of large firms (the top twenty firms ranked by market capitalization of common equity at the end of 1995 in each of 27 countries), the controlling families also participate in management. Participation is defined as a family member (sharing the same family last name) being the CEO, the Chairman, the Honorary Chairman, or the ViceChairman of the firm. The reported percentage underestimates the actual involvement of family members in executive position because executives married into the family may not share the family name. Claessens et al. (2000) report that, in East Asian countries (Hong Kong, Indonesia, Japan, South Korea, Malaysia, the Philippines, Singapore, Taiwan, and Thailand), professional managers are rare, and family members or trusted associates are usually in charge. Top managers are family members in about $60 \%$ of firms that are not widely held. These studies are about controlling family participation in general, not controlling family participation in the management of pyramid member firms in particular. Empirical exploration of this issue is needed. For Italy, however, Volpin (2002) presents data about family members participation in firms that belong to pyramidal groups. He finds that $50 \%$ of top executives in the top layer of a pyramid are members of the controlling family. For lower layers, the figure is smaller: $26 \%$ for layer two firms, and $7.4 \%$ for layers three and below.

The discussion in this subsection leaves us with the following important points. By using pyramids and, to a lesser extent, crossholdings, super-voting shares, and the appointment of family members as executives, a wealthy family can secure control of a corporation without making a commensurate equity investment. Pyramids in particular allow a divergence of voting rights from cash flow rights much greater than is typically possible through direct ownership. Pyramids thus allow a family with a given level of wealth to control corporate assets worth considerably more than direct ownership would permit.

\section{Other Types of Group Control}

La Porta et al. (1999) show that control pyramids are by far the most important corporate group structures, but publicly traded companies can control each other in other ways. These generate other group structures that are important in particular countries. For example, Japanese firms are organized into groups called keiretsu, in which firms with no controlling shareholders each hold small stakes in one another, but these stakes collectively amount to control blocks. Thus, each firm is controlled by the professional managers of all the other firms in the group. France, Canada, Germany, and other countries also contain control pyramids without family firms at the apex. In some cases the apex firm is itself widely held. In France and Canada, some control pyramids of publicly traded firms have state-owned enterprises as their apex firms. In Germany, banks sometimes serve as de facto apex firms. Since public shareholders in German firms routinely sign over their voting rights to the banks that manage their stock accounts, these control pyramids can consist of nominally widely held firms held together by banks voting the holdings of small shareholders. The large German banks are all widely held, so the bank managers 
collectively vote majorities of their own stock. ${ }^{2}$ Recent reforms require German banks to advise investors of their right to vote their own shares, and this may effectively dismantle such structures over time. Of course family control pyramids are also important in all of these countries. We use the term corporate group to refer to all of these structures collectively, and reserve the term family control pyramid for business groups with a basically pyramidal structure of inter-corporate ownership and a family firm at the apex.

\section{A Few Wealthy Families Control a Large Fraction of Many Economies}

That family control is widespread around the world is perhaps interesting, but hardly unsettling. What makes this situation important to understanding of economies outside the United States and United Kingdom is that control pyramids concentrate a country's corporate decision-making in remarkably few hands.

The articles surveyed above are filled with representative examples.

As discussed, in §IIIB, Morck et al. (2000) describe how the Canadian Bornfman family extends its considerable wealth into control over corporate assets worth vastly more. Attig, Gadhoum and Lang (2003) add descriptions of the Manix, McCain, and the Bentley families. La Porta et al. (1999) discuss yet other examples of Canadian control pyramids. While these examples show how wealthy Canadian families greatly magnify their economic control, Morck et al. (2000) report that widely held firms are also commonplace in that country. Thus, no single family controls a predominant slice of the national economy.

Contrast this to Sweden, where Angblad et al. (2001, p. 228) report that one family, the Wallenbergs, controls roughly half of the market capitalization of the Stockholm Stock Exchange. This is accomplished through a huge and complicated control pyramid. What distinguishes Sweden from Canada is that control rights in Swedish firms are substantially in the hands of a single family, rather than a handful of families and numerous professional managers.

Other countries typically fall between the extremes represented by Canada and Sweden. For example, La Porta et al. (1999), Bianchi et al. (2001), and Faccio and Lang (2002) describe the control pyramid that lets the Agnelli family control corporate assets worth vastly more than their actual family wealth in Italy. Faccio and Lang (2002) further report that the Agnellis control $10.4 \%$ of that country's total market capitalization. Overall, across Western Europe, the value of corporate assets controlled by the leading family, measured as a fraction of market capitalization, ranges from $18 \%$ in Switzerland to only $1.10 \%$ in the United Kingdom. For the ten largest families, the figures are 19\% for Austria, 30\% for Belgium, 22\% for Finland, 29\% for France, 21\% for Germany, 14\% for Ireland, 20\% for Italy, 23\% for Norway, 34\% for Portugal, $11 \%$ for Spain, 13\% for Sweden, 29\% for Switzerland and only 4\% for the United Kingdom.

Gorton and Winton (2003) describe extensive pyramiding in Germany. They argue that German banks' exercise of proxy voting rights for shares owned by small investors effectively creates pyramids of seemingly widely held firms with large banks at the apex. The large banks are widely held, so their shares are voted by the banks and their affiliated insurance companies.

East Asian economies tend to resemble Sweden more than Canada. Claessens et al. (2000) find that the top fifteen family control pyramids in typical East Asian economies hold corporate assets worth a large fraction of GDP - 84\% of GDP in Hong Kong, $76.2 \%$ in Malaysia, $48.3 \%$ in Singapore, $46.7 \%$ in the Philippines, and 39.3\% in Thailand (these are the largest numbers reported). They state (p. 109) that, "these results suggest that a relatively small number of families effectively control most East Asian economies". They also find that the single

2 Along with the managers of large insurance companies, affiliated with the banks. 
wealthiest family controls $17.1 \%$ of the market capitalization in the Philippines, $16.6 \%$ in Indonesia, and $11.4 \%$ in South Korea.

La Porta et al. (1999) report that Huchison Whampoa, the third largest listed firm in Hong Kong, is $43.9 \%$ controlled by Cheung Kong Holdings, the fifth largest listed firm, which is $35 \%$ owned by Li Ka Shing family. Li Ka Shing, through a pyramidal arrangement, controls three of the twenty largest firms, including the eleventh largest, Hong Kong Electric Holdings. Claessens et al. (2000) provide further description of the Li Ka Shing control pyramid.

Claessens et al. (2000) describe the extensive control exercised by the Ayala pyramid in the Philippines. The Ayala Corporation, the second largest listed firm on the Manila Exchange in terms of market capitalization, controls Ayala Land, the largest. The Bank of the Philippine Islands, the fifth largest, also belongs to the Ayala control pyramid. The principal owner of the Ayala corporation is the privately held Mermac Inc. The Tokyo Mitsubishi Bank controls 23\%, and others control less than $5 \%$ each. Mermac is $100 \%$ controlled by the Ayala family.

Bae, Kang, and Kim (2002) describe the importance of Korean family controlled pyramids, or chaebols. Chaebol, while basically pyramidal in nature have extensive reciprocal holdings as well as simple pyramidal intercorporate ownership links. The top thirty chaebols "contribute to $62.5 \%$ of the total assets and $72.6 \%$ of the gross sales of all listed firms" (p. 2699) and each is diversified across many unrelated industries. Each is also controlled by a single wealthy family (p. 2702).

Figure 3 shows the wealth of billionaires as a fraction of GDP, expressed as dollars of billionaire wealth per thousand dollars of gross domestic product.

Figure 3. Billionaire Wealth per Billion Dollars of GDP

Billionaire nationalities as listed in Forbes Magazine's annual list of US dollar billionaires for 1996.

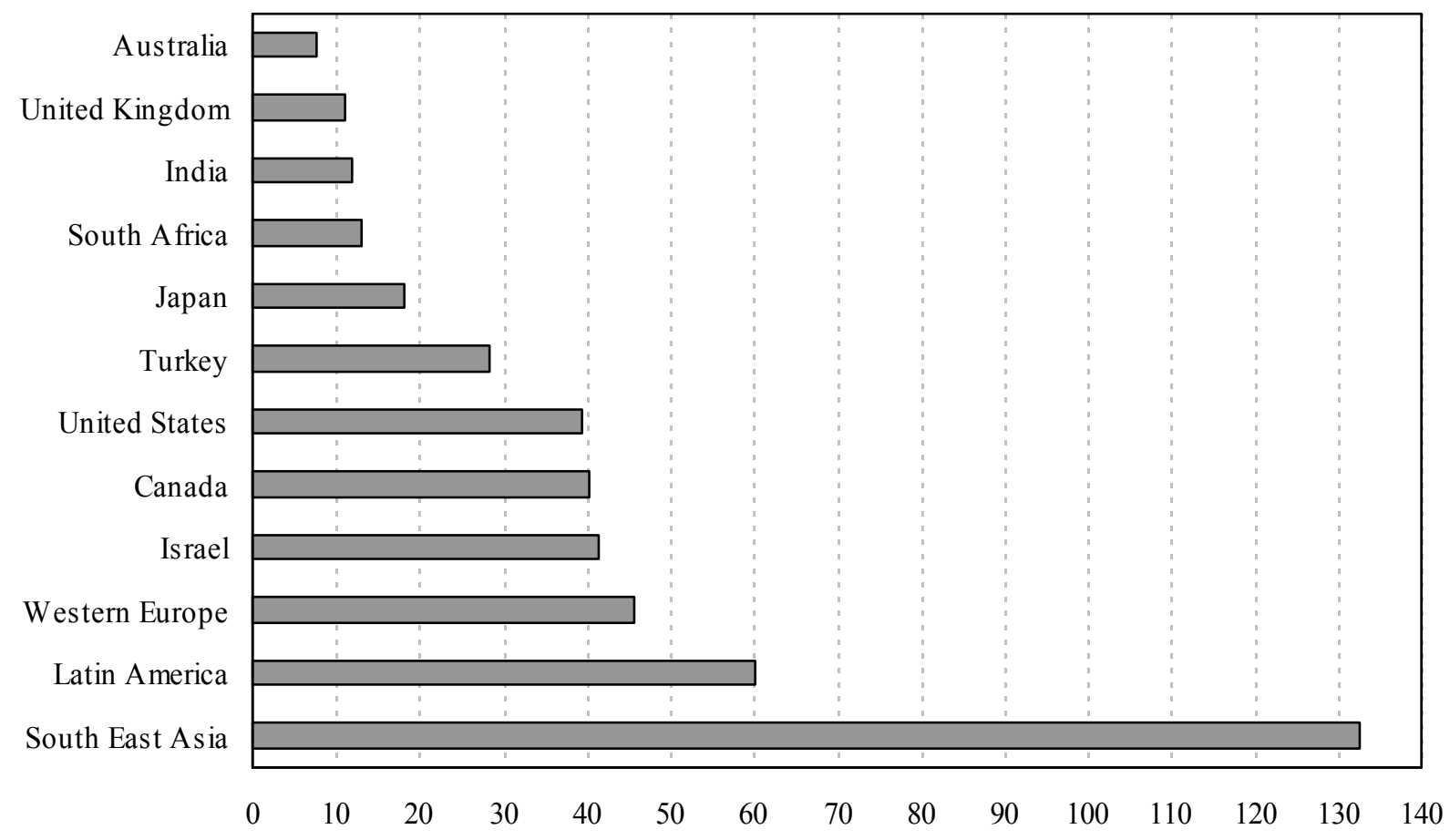

Source: Morck, Stangeland, and Yeung (2000). 


\section{E. Summary}

These findings in this section condense into three crucial points. First, the prevalence of widely held firms in the large corporate sectors of the US and UK is highly exceptional. Second, the large corporate sectors, excluding state-owned enterprises, of most countries are predominantly controlled by very wealthy families. Third, the number of wealthy families exercising this control is typically quite small because control pyramids translate substantial family wealth into command of corporate assets worth vastly more. In some countries, individual families use this technique to control considerable, and even predominant, slices of the country's market capitalization.

Further careful empirical work is clearly needed to verify the actual extents to which these points genuinely characterize different countries. But assuming they are correct, they raise a curious question: Why are pyramidal firm groups so much rarer in the United States and United Kingdom? Or, are pyramidal groups a heretofore neglected aspect of corporate governance in the United States and United Kingdom?

\section{Potential Benefits of Control Pyramids}

We now examine the impact of such disproportionate control over a country's corporate assets by tiny elites of extremely wealthy individuals and families - both at the firm level and at the economy level. We first review work consistent with dominant shareholders exerting a positive effect on firm performance. We note that much of this work does not carry over from freestanding firms with dominant shareholders to pyramidal groups. We then turn to negative effects in Section V.

\section{A. The Performance of Freestanding Family Controlled Firms}

Several studies suggest that family control per se might often have a positive effect on firm performance. Anderson and Reeb (2003b) study 403 firms in the Standard and Poor's 500, an index of large U.S. firms. They find that about one-third of them have individuals or families as substantial shareholders, holding altogether $18 \%$ of equity value. Using data for 1992 through 1999, excluding utilities and banks, they regress Tobin's average $q$, a standardized measure of firm valuation and a well-accepted proxy for the quality of corporate governance, on a standard set of control variables plus individual and family ownership and dummies for the presence of a founder or heir as CEO. ${ }^{3}$ They report that public shareholders assign substantially higher values to firms with a large block held by an individual or family. They report an especially large value premium for firms whose founders retain equity holdings, and a smaller, but still statistically significant value premium for firms with other large individual or family shareholders. Anderson and Reeb (2003a) use the same sample and find that family controlled firms are less diversified, after controlling for size, outside directors and block shareholders. They conclude that "family firms perform as well as, if not better than, non-family firms."

Morck et al. (1988) reach the same conclusion for US firms in which the founder or a member of the founding family is present in management and the firm was incorporated within the previous thirty years. But for older firms with founders or their relatives in management, they report a significant value discount. Holderness and Sheehan (1988) report no systematic performance difference associated with large US shareholders. However, Perez-Gonzalez

\footnotetext{
3 Tobin's average $q$ is the market value of all the firm's financial obligations over the total value of its physical and intangible assets. An average $q$ above one, adjusting for appropriate control variables, is interpreted as evidence that managers have used the firm's assets to create value for investors. See Morck et al. (1988) for further detail.
} 
(2002), using United States data, divide 162 CEO transitions where the retiring CEO is a member of the founding family into cases where the succeeding CEO is a member of the founding family and cases where she is not. Stock prices, returns on assets and market-to-book ratios fall sharply for firms with inherited control, but not for firms where the CEO is unrelated to the founding family. Moreover, these declines are particularly prominent for firms that appoint family CEOs who did not attend a selective college. Indeed, the differences between firms with outside succession and in-family succession by an offspring alumnus of a selective college are not statistically different. Clearly, these results suggest that large blockshareholdings by a family, and family involvement in management, need not destroy value, and may even add value for public shareholders - especially when family control means control by an entrepreneurial founder or a demonstrably competent heir. Further studies along these lines for other countries would be highly useful.

Similarly, in an event study using Canadian family controlled firms, Smith and AmoakoAdu (1999) report share price drops when heirs take charge - especially if the heirs are young. They propose that older heirs, with more business experience, might reassure investors.

Caselli and Gennaioli (2003) develop a model of dynastic management - the passing of control from father to son. In their model, this is a potential source of inefficiency because heirs may inherit little of their parents' talent for managerial decision making. They explore the macroeconomic causes and consequences of dynastic management, and derive that the incidence of dynastic management depends on the severity of asset market imperfections, the saving rate, and the inheritability of talent. Using numerical simulations, they show that dynastic management may be a substantial contributor to observed cross-country differences in productivity.

Unfortunately, the empirical results cited above, except Smith and Amoako-Adu (1999), use U.S. data. Further studies using data from other countries are needed. This is because US data is exceptional for its lack of control pyramids, and for the rarity and fleeting nature of its intercorporate blockholdings. Allen and Phillips (2000) report 227 instances of one U.S. firm buying blocks of stock in one another from 1980 to 1991. These equity stakes are usually small; averaging $15 \%$ of the seller's equity, and so are referred to as toeholds. This is because they are often preliminary to complete takeovers. Indeed Mikkelson and Ruback (1985) and Choi (1991) can explain positive announcement abnormal returns associated with such purchases by the anticipation of subsequent takeovers. In some cases, joint venture partner firms may also exchange blocks of stock. Thus, U.S. inter-corporate equity blocks are usually between pairs of otherwise freestanding firms. The only extant pyramidal structure in the United States, to our knowledge, is the venture capital organization, Thermo Electron, which retains control blocks in its high technology public spin offs. Thus, family control and inter-corporate blockholdings in the U.S. are quite atypical; for wealthy U.S. families seem virtually always to control but a single large publicly trade firm. In contrast, the previous section showed that family control and intercorporate block shareholdings elsewhere are often associated with control pyramids that extend a single family's control over many large corporations.

The US results described above allow that, in freestanding firms, family control might sometimes be a net advantage. However, findings regarding freestanding firms cannot be applied hastily to pyramid firms, and empirical studies suggest important differences. For example, Morck et al. (2000), after controlling for firm age, size and main industry, report that Canadian heir controlled firms are less profitable than otherwise comparable firms in the US and in Canada. One possible explanation is that typical Canadian heirs running large firms are worse 
managers than their US counterparts. Another is that many large Canadian firms belong to pyramidal groups. While we cannot preclude the former reason, the latter seems more immediately plausible. We therefore consider ways in which pyramidal structures might affect firm performance - positively and negatively.

\section{B. Could Control Pyramids Have Positive Effects?}

Control pyramids must be of value to someone, or they would not predominate as they do in many economies. An emerging empirical literature attempts to identify advantages conferred by family control pyramids. We review some of the most important contributions.

Khanna and Rivkin (2001) examine firms affiliated with business groups in Argentina, Brazil, Chile, India, Indonesia, Israel, Korea, Mexico, Peru, the Philippines, South Africa, Taiwan (China), Thailand, and Turkey. They define a business group as "a set of firms which, though legally independent, are bound together by a constellation of formal and informal ties and are accustomed to taking coordinated actions." They note that this definition "captures 'ties' that hold group firms together and the coordinated actions those ties enable." Thus, they are examining control pyramids run by families as well as other corporate groups; however, most of the groups they examine appear to be family control pyramids. They report higher average returns on assets (ROA) among group firms in all the countries they study save Argentina, Brazil, Chile, Mexico, Peru and the Philippines. They also find lower variation in ROA for group firms, except in Mexico and Turkey. From these findings, they conclude "not only that members of a group incur costs and reap benefits, but also that the costs and benefits are shared."

Khanna and Palepu (2000a) compare the performance of member firms of Indian business groups, which are family control pyramids, with that of freestanding firms. Some of these business groups span many distinct industries, while others are more focused. They find that accounting and stock market measures of firm performance for group affiliates have nonmonotonic relationships with group diversification. Firms in somewhat diversified control pyramids perform worse than free-standing firms, while firms in highly diversified control pyramids perform better than their freestanding peers. Apparently, a high level of diversification ultimately benefits group affiliates.

Khanna and Palepu (2000a) and Khanna and Rivkin (2001) both explain their findings by positing various arguments as to why the group structure might be an advantage in economies with poorly functioning markets and institutions that might cause unrelated firms to have difficulty writing and enforcing contracts with each other. The idea that groups mitigate market frictions goes back to Leff $(1976,1978)$.

One set of arguments stems from the need to overcome capital market frictions. In economies where information asymmetry is severe and institutional devices to signal trustworthiness are inadequate and ineffective, external financing is expensive and limited. A group structure can enhance monitoring and overcome liquidity constraints by letting group firms pool resources. The pyramid's controlling shareholder could potentially allocate capital more efficiently than the weak capital market could. Yet, reliance on such an "internal capital market" can distort the incentives of unit managers. This is essentially the same "internal versus external capital market argument" that Lewellen (1971), Gertner, Scharfstein, Stein (1994) and Stein (1997) develop in connection with freestanding U.S. conglomerates.

In a similar vein, Burkart, Panunzi and Shleifer (2003) examine whether entrepreneurs want to surrender control of firms they found. They accept the potential benefits of owner control, but pitch them against the utilization of outside capable professional managers. When 
the benefits are less than the forgone benefits of rendering control to capable outside professional managers, a case may exist for surrendering control. Outside professional managers, however, may expropriate firm value. Thence, the forces that factor in on the question of whether to surrender control are the amenities and benefits of running a family business verse the extra firm value capable professional managers can bring in net of their expropriation and the monitoring costs. The latter is less in an environment where managers can more readily disregard outside shareholder's property rights. The lack of separation between management and ownership control is evidence of underdevelopment in financial markets.

Most of the results which show that "groups" may have a positive effect on firm performance are based on developing or newly developed countries data. It is not clear whether the lack of reported results for developed countries indicates lack of empirical attempts using developed country data or that it validates the theoretical arguments like in Burkart, Panunzi and Shliefer (2003). [Journals seem to have a bias against publishing papers that report insignificant statistical results.]

More generally the arguments proposed by Khanna and Palepu (2000a) and others stem from the need to overcome frictions in factor markets. In essence, markets for capital, managerial talent, and intangibles are internalized within groups because external markets are poorly developed. When institutions are weak, doing business with strangers is dangerous and unreliable. This impedes the operation of labor, capital, knowledge, and product markets. However, families with reputations for fairness and good management practices are especially sought after as business partners in such environments. Control pyramids let families with good reputations achieve greater economies of scale, and thus allow a higher degree of trust than would otherwise be possible. This, in turn, facilitates economic activity. Control pyramids may well be an economically rational response to poorly functioning markets in developing economies. In economies where external markets for professional managers are thin and underdeveloped, a group's internal market structure can lead to more investment in recruiting, training, and greater incentives for employees to develop "group specific human capital". Similar considerations apply to the development of market skills and brand-names.

A separate argument turns on the relationships between a firm's stakeholders - the various claimants to its cash flows such as the State, the public, the firm's workers, creditors, suppliers, customers, and various types of its shareholders. Roe (2003) argues that family control pyramids serve to protect shareholders from powerful labor unions and other social interests. These arguments are perhaps plausible as explanations for the prevalence of control pyramids in developed welfare state economies like Sweden and Canada, but, as Roe (2003) concedes, they seem inadequate at explaining their persistence in developing economies. In support of his argument, Roe (2003) shows that countries with more socialistic politics and stronger labor rights have less dispersed ownership. One difficulty we have with the Roe (2003) argument is that causality is not easily determined. Leftist politics and strong labor movements might just as easily form to counter the power of wealthy families controlling multiple corporations. Another difficulty with Roe's argument is that pyramids give controlling shareholders interests that can sharply diverge from those of public shareholders. Further work is clearly needed to clarify these issues.

\section{But, why Pyramids?}

The literature positing positive effects of pyramidal structures, whether derived from Khanna and Palepu (2000a) or Roe (2003), begs the question why pyramidal groups form, instead of 
freestanding conglomerates. Research on this question is very sparse, as far as we know. We can therefore only offer several conjectures.

First, separately registered firms might provide at least some limited liability protection, so that a parent firm's losses not exceed its initial investment. Limited liability, however, also reduces outside investors' ability to recover their investments in case of a loss. In addition, limited liability need not always provide full protection. For instance, Morck and Nakamura (2004) show that, when the Suzuki group's Taiwan Bank failed in 1930s Japan, all the other companies in the Suzuki family's pyramid failed simultaneously too.

Second, a pyramid might create space for the promotion of bright executives to top management positions. Perhaps these people would be frustrated as middle managers in a big conglomerate. Also, running a legally separated unit may give these executives more freedom and perhaps might create better career incentives. However, this freedom is likely to be quite illusory because the controlling family often retains executive decision power.

Third, many smaller firms, rather than one huge one, might conceivably allow better monitoring of professional managers by the family. Pyramids might be less opaque than a single conglomerate - to the controlling family, if not to public shareholders. This point and the previous one are consistent with Baker (1992), who proposes that conglomerates are more efficiently run when head office delegates as much power as possible to operational units. It is possible that pyramidal groups insulate individual operations from the head office more effectively than conglomerate divisions. However, we are unaware of any evidence regarding this.

Fourth, many US conglomerates have recently issued tracking stocks. These are stocks whose dividends are tied to a single division of the conglomerate. D'Souza and Jacob (2000) report a positive abnormal stock return upon the creation of tracking stocks, indicating that many related stocks controlled by the same top managers are worth more than a single conglomerate's stock. They propose that distinct stocks might allow readier resolution of information asymmetries and principal agent problems, and Gigler and Hemmer (2002) provide an information theory model along these lines. Perhaps analogous models apply to pyramidal and other corporate groups.

Fifth, Hoshi, Kashyap, and Scharfstein (1991) argue that Japanese firms provide capital to other firms in their corporate groups that are experiencing financial difficulties. They propose that this intercorporate insurance enhances economic efficiency by reducing bankruptcy costs. Although, Morck and Nakamura (1999) present evidence that such transactions are better be viewed as bailouts, and are probably not economically efficient, corporate groups in other countries might still perform the function Hoshi et al. envision.

Sixth, Almeida and Wolfenzon (2003a) argue that capital market frictions induce pyramids. In their model, weak investor protection keeps firms from raising external finance unless internal funds are available as "seed money". If a wealthy family sets up a new freestanding firm, it has only family wealth available as seed money, which should include dividends paid from firms it controls. But if it uses an existing firm to set up a new one, the accumulated retained earnings of that firm are available as "internal funds".

Of course, this framework fails to explain why the wealthy family doesn't simply expand an existing firm by issuing equity or debt. However, as Landes (1949) points out in connection with French family firms, equity issues dilute the family's control block and debt issues raise the risk of bankruptcy. Both modes of expansion thus raise the risk of the family losing control. 
In essence, Almeida and Wolfenzon (2003a), augmented by wealthy family's desires to retain control, echo the explanation of Yoshisuke Aikawa (1934), the founder of the Nissan pyramidal corporate group in pre-war Japan, of why he opted for a pyramidal structure. He explains that pyramids are an ideal solution to what he calls the "capitalist's quandary". If a capitalist uses only his own money or his family's money, his scale of operations is too small. If he taps public equity markets, he risks losing control. But, as discussed above in connection with Figure 1, a pyramidal group provides the best of both worlds - secure control and unlimited access to public capital. ${ }^{4}$

Finally, Morck et al. (2000) and Morck and Yeung (2004) propose that political influence is proportional to what one controls, not what one actually owns. As we explain in more detail below, this might allow the controlling owners of pyramidal groups unrivaled political influence in many countries. Morck and Yeung (2004) argue that, by magnifying the wealth of an individual or family into control over corporate assets worth vastly more, pyramids magnify political influence in the same proportion. The wealthy individual or family can use this amplified political clout to alter the economy's institutional framework to favor themselves or their firms, to capture transfer payments, and so on. This advantage might be considerable, especially in economies with readily corruptible politicians and officials. Indeed, it might be so large as to explain apparently superior firm level performance, as found by Khanna and Pzalepu (2001a) and Khanna and Rivkin (2001), despite obvious evidence of poor governance and overall poor economy performance. Krueger (1993), Murphy et al. (1991, 1993), and many others argue that economies in which political rent-seeking is highly profitable grow slowly. If pyramidal groups prosper because they are especially adept rent-seekers, they perhaps ought to contain the best performing firms in the worst performing countries. Further work is needed to clarify these issues.

\section{Control Pyramids and the Separation of Ownership from Control}

The discussion above suggests that, even were control pyramids economically salubrious, for example as devices for circumventing inadequate institutions, there are nonetheless reasons for taking a more skeptical view. Certainly, Yoshisuke Aikawa's (1934) enthusiasm for control pyramids demonstrates scant concern for the rights of public shareholders.

The first reason for skepticism is that a pyramidal corporate ownership structure allows the controlling shareholder to secure control rights without commensurate cash flow rights. Secure control rights protect the controlling owner from losing power - that is, they allow her entrenchment. Furthermore, as we show below, once control is secured, the controlling shareholder's low cash flow rights lead to agency problems, including non-value maximizing investment and incentives to divert resources.

Second, in family-controlled pyramids, family members often retain top management positions. Succession by inheritance can have a negative effect because top management positions go, not to the most capable, but, at best, to the most capable member of the controlling family, as modeled by Caselli and Gennaioli (2003).

Third, even were resources efficiently managed and allocated within a group controlled by single family, corporate groups can still be undesirable. Almeida and Wolfenzon (2003b) argue that the efficient allocation of resources within a group can actually exacerbate the inefficient allocation of resources across groups.

4 See Morck and Nakamura (2004) for details. 
Finally, the concentrated control of productive assets by a few families gives them market power, both in the goods and capital markets, leading to potentially undesirable economic consequences. Morck and Nakamura (2004) explain how this was the explicit rationale cited by the United States Occupation Force for dismantling the main Japanese family control pyramids after World War II.

Widespread problems of these types, especially those that impair capital markets, can create inefficiencies that hamper outside financing, discourage innovation, and retard economic growth. These inefficiencies can arise at both the firm level and overall economy level. In this section we focus on inefficiencies at the firm level. These stem primarily from the separation of ownership and control in the pyramid - the first two points enumerated above. The next section focuses on inefficiencies at the economy level which stems from the control of a very large number of firms by a single family - the last two points listed above. This section is deliberately brief, for other surveys, notably Shleifer and Vishny (1997) and Denis and McConnell (2003) cover some of this material, though not from the perspective we emphasize here.

\section{A. Divergence of Interests Agency Problems}

The problems caused by the separation of ownership and control in pyramidal groups are similar to those described in Berle and Means (1932) and Jensen and Meckling (1976) in connection with widely held firms. Indeed, Berle and Means (1932) explicitly describe pyramids as having problems like those of widely held firms. Jensen and Meckling argue that the managers of firms with dispersed shareholders have substantial discretion as to the actions they take because individual shareholders cannot coordinate to share monitoring and control costs. This lets managers take actions with benefits that, by their nature, are not shared with shareholders. In addition to indirect financial benefits, like on-the-job consumption or shirking, and direct financial benefits, like redirecting corporate assets into a personal account, control also provides intangible benefits, like status, political influence, and power over people. The literature denotes all of these benefits as private benefits of control. Managers pursue private benefits, but balance this against their losses when the price of their shares in the firm falls plus the consequences of getting "caught and punished," such as losing their jobs. This balance means managers might choose an action with lower total value over one with higher value, as long as the former generated sufficient private benefits. This divergence of interests is greater the lower the managers' equity stake and the lower the likelihood of her getting caught and punished for nonvalue maximizing behavior.

As we described in section 3, firms outside the United States and United Kingdom are owned, not solely by dispersed small shareholders, but by wealthy families via control pyramids. Pyramids allow a family to retain control of many firms while holding only a small fraction of their cash flow rights. Indeed, we presented examples in which the cash flow rights of the controlling family in some of the pyramid member firms are comparable to the stakes of the managers of the most diffusely held of U.S. corporations. By allowing cash flow rights and voting rights to diverge, control pyramids permit the same divergence of interest problems as dispersed ownership, even though the firms in the pyramid are not widely held.

This divergence of interests can lead to inefficient investment in firms in which a controlling owner has small cash flow rights. This is because the controlling family earns only a small part, corresponding to its small cash flow rights in such a firm, of any investment's monetary payoff, but can retain all of any private benefits the investment generates. Only in the 
special case of an investment that maximizes total surplus also maximizing the controlling owner's private benefits should we observe efficient investment decisions.

A related reason for inefficient investment arises from the high cost of capital that this divergence of interest entails. This high cost stems from minority shareholders' rational expectation that this divergence of interest distorts corporate decisions to benefit controlling shareholders. Such problems are defined in the Corporations Law of many countries as oppression of public shareholders by the controlling shareholder. Oppression problems are thus a variant of "perks" consumption, where the perks are diversions to benefit the controlling shareholder rather than professional managers. La Porta et al. (1999) document countries varying substantially regarding the protection their laws afford external investors against oppression. Shleifer and Wolfenzon (2002) show that, when a controlling shareholder has a low cash flow stake, as with firms at the base of a pyramid, the cost of capital to the firm is high since other investors anticipate expropriation, and pay depressed prices for any securities that firm sells. A consequence of this high cost of capital is severely distorted investment decisions because of those firms' reluctance to raise external funds.

\section{B. Entrenchment Agency Problems}

The corporate finance literature notes a second type of agency problem, called entrenchment. While Jensen and Meckling (1976) argue that insiders with larger stakes have less incentive to misallocate corporate resources, Stulz (1988) argues that higher equity stakes also give insiders more freedom to misallocate resources. This is because top executives who own large blocks of equity are effectively tenured. Non-value-maximizing managers with little stock can be removed in proxy fights by disgruntled institutional investors or ousted by hostile raiders attracted by a depressed share price. Top executives with large blocks of equity cannot be cast out in these ways. Thus, a dominant equity stake lets corporate insiders enjoy private benefits of control robustly, whereas a smaller stake means they must limit their inhalation to keep their share prices high enough to ward off raiders and placate institutional investors.

Moreover, entrenchment problems can take on a qualitatively distinct air, for entrenchment can lock in control by honest but inept insiders as well as clever self-serving insiders. For example, entrenchment problems occur if a firm's controlling founder bequeaths her stock to an egregiously incompetent, but power hungry son. The incompetent son cannot manage the firm well, but cannot be removed by the other shareholders because his share of votes is sufficiently large to control the board. The power hungry son gains such utility from controlling the firm that the effects of his blunders on the value of his stock are an acceptable cost to him. While this might even be Pareto efficient, it clearly raises important distributive questions, to which we return below. This sort of entrenchment is especially difficult to counter, for if the controlling shareholder used his control rights to enrich himself pecuniarily at the expense of public shareholders, this could be proscribed as "oppression".

Of course, this picture is overly simplified. In principle, without maintaining a dominant voting share, the CEO of a widely held firm could also dominate the board through sheer force of personality, and push through an array of anti-takeover defenses, such as poison pills, staggered boards, and the like, to deter raiders and activist shareholders.

Managerial entrenchment can occur in freestanding firms. Indeed, Almazan and Suarez (2003) argue that a degree of entrenchment might be part of an optimal compensation contract for top managers. Nonetheless, as Nissan founder Yoshisuke Aikawa's (1934) unwittingly emphasized, a fundamental raison d'être of control pyramids is precisely that they lock in 
control. That is, a pyramidal structure is itself a means to entrench the controlling shareholder without the cost of maintaining a large equity stake, nor the machinations of having to establish poison pills or staggered boards. Control pyramids per se are simple and highly effective antitakeover devices.

To see this, return to Figure 1 and recall the discussion in $§$ IIIB. The family appoints the boards of directors of companies in the first tier, and so can place family members in dominant positions on those boards and as top executives. The first tier firm's boards then appoint the boards of companies in the second tier, which then appoint the boards of companies in the third tier. This locks in family control over all the companies in the pyramid, even though public shareholders contribute most of the financing for most of its firms. In contrast, had the family established a single firm with eight billion dollars worth of physical assets (a union of the firms in the third layer), its billion dollars in family wealth would have constituted a $12.5 \%$ stake, and public shareholders could outvote the family in shareholder meetings. This would render family control contestable.

Note further that entrenchment via control pyramids is intimately linked to the appointment of family members to the boards of the apex firm and other firms throughout the pyramid. The example above - allowing "an egregiously incompetent, but power hungry son" to retain control - underscores the potential for damage to firm value due to entrenchment. But, the potential for damage goes beyond the controlling manager having excessive freedom to pursue her self-interest at the expense of firm value. It also includes the possibility that an incompetent manager might retain her job precisely because she can extract more personal gains from the job than a competent manager could. Indeed, Bebchuk, Kraakman, and Triantis (2000) suggest that control might naturally pass to "the most efficient thief" because he is willing to pay the most for a control block.

\section{Tunneling}

The firms low in control pyramids, in which the controlling shareholder's cash flow rights are small, are thus vulnerable to concurrent divergence of interests and entrenchment problems. One consequence of this juxtaposition is that the controlling shareholder has an incentive to transfer money aggressively out of these firms and into firms near the pyramid's apex - or even into her personal holdings. Of course, these transactions can require complex schemes to be effective. Nonetheless, when the controlling family runs many firms, they can take the form of intercorporate business transactions.

The act of transferring value from one pyramid firm to another is dubbed tunneling by Johnson et al. (2000). ${ }^{5}$ Value can be transferred between controlled firms via transfer pricing, the provision of capital at artificial prices; or via inflated payments for intangibles such as patents, brand names, and insurance. Although the firm at the receiving end of the tunnel benefits from the wealth transfer, public shareholders of the wealth donating firm understandably might view the transfer as a governance problem. Johnson et al. (2000) provide detailed examples of tunneling.

The transfer of funds from one group firm to another is integral to many of the socially desirable functions of corporate groups posited above. Tunneling undertaken with such ends in

\footnotetext{
${ }^{5}$ Tunneling is of course another type of agency problem, but we treat it separately here due to its importance. An agency problem is one where an agent, in this case controlling family, can take actions that negatively affect the utility of the principal, in this case the minority shareholders. In this sense, both entrenchment and tunneling are agency problems.
} 
mind perhaps ought to be encouraged, not condemned as a governance problem. Indeed, such transfers might well balance out over time for any given group firm.

However, the controlling owners of pyramids benefit from the systematic percolation of wealth from firms near the pyramid's base upward to firms near its apex. To see this, return again to Figure 1. Suppose that firm 3,1 generates new wealth worth one million dollars. As was shown above, this translates into additional wealth of $\$ 125,000$ for the ultimate owners. The remaining $\$ 875,000$ accrues to public shareholders in the various tiers of the pyramid. But if firm $_{3,1}$ overpays firm 1.1 by one million dollars for some good or service, the new wealth is "tunneled" to firm ${ }_{1,1}$. This means the controlling owner benefits by $\$ 500,000$ and the public shareholders of firm 3,1 and firm 2,1 get none of the new wealth. In the most extreme case of tunneling, the wealth is transferred directly to the family firm at the apex, or to another firm that is fully owned by the family. ${ }^{6}$ In these ways, tunneling lifts assets and income from lower to higher tier firms, and dumps losses and liabilities from higher to lower levels of the pyramid.

Tunneling does not require a control pyramid of firms. For example, the Enron scandal in the United States apparently involved the transfer of wealth from Enron, a widely held company, to private companies controlled by Enron's professional managers. However, tunneling is plausibly a more everyday concern in economies dominated by control pyramids.

In passing, tunneling should be familiar to students of multinationals, which are known to engage in an analogous shifting of earnings and assets to avoid declaring income in high tax countries. The key differences are: (1) tunneling is about hiding money from public shareholders, while income shifting by multinationals is about hiding money from the tax authorities; and (2) tunneling can involve solely domestic firms. IN both cases, however, the shifting of assets and liabilities among a multitude of related corporations complicates the workings of the firms in question and renders them less transparent to investors.

In summary, freestanding firms are most vulnerable to divergence of interests agency problems if widely held and to entrenchment problems if narrowly held, though this is an oversimplification. In contrast, firms in lower tiers of control pyramids are vulnerable to both problems simultaneously. Their dual presence is mutually reinforcing. Entrenchment allows a more fulsome divergence of interests agency problem, which raises the value of becoming entrenched, including maintaining the pyramidal structure and keeping family members in key executive positions and on key boards. Tunneling further exacerbates both problems by allowing an entrenched controlling shareholder to appropriate corporate resources and to raise a corporate veil against outsider monitoring.

This unhappy confluence of firm-level corporate governance problems means that less able managers who particularly value control are especially likely to be locked into positions of corporate power, and that inefficient investment might plausibly be associated with control pyramids. ${ }^{7}$ If these problems are isolated incidents, any macroeconomic effects are marginal.

\footnotetext{
6 In practice, the process of tunneling might well destroy part of the wealth being transferred, so the controlling owner might net less than the full million dollars because of lawyers fees, payments for discrete financial services, and the like. We return to this point below.

7 One might expect poor corporate governance to raise a firm's outside capital costs. The issue, however, is complicated. A firm's cost of outside capital is affected by many factors. Pyramidal groups might have capital market power so that their firms' costs of outside capital might even be lower than those of stand alone firms. For example, pyramidal firm groups might be more favored clients of banks than stand alone firms because of their sheer size, or the pyramids themselves might contain banks. The prevalence of pyramidal groups has implications on capital market conditions and hence on the overall allocation of outside financing in an economy. We revisit these issues below.
} 
Indeed, pyramid firms with poor corporate governance ought to be out-competed, and their neglected investment opportunities ought to be appropriated by better-run firms. However, if control pyramids allow a very small number of controlling shareholders to amass control over so many firms that they govern a substantial part of the corporate sector, their sub-optimal behavior might aggregate to a macroeconomics problem.

Whether these problems outweigh any positive effects associated with pyramidal control is unclear a priori. Corporate governance problems might plausibly be expected to dominate in situations where the controlling shareholder is less able, entrepreneurial, or honest. The beneficial effects listed earlier in this section might plausibly dominate where entrepreneurial talent is scarce, market institutions are weak, bankruptcy costs high, and so on. The actual balance is thus an empirical question.

\section{Empirical Evidence}

We now review a large literature that helps us answer this question. While some of this work focuses on freestanding firms, it nonetheless allows us to make carefully guarded inferences about control pyramid firms. While a rapidly growing body of work also focuses specifically on pyramid firms, further effort along these lines is likely to be highly productive.

\section{Firm-Level Studies of Performance}

As mentioned above, Khanna and Palepu (2000a) and Khanna and Rivkin (2001) both find that firms belonging to pyramidal groups in developing countries outperform independent firms on average. This could be due to any of the explanations listed above for business groups having an advantage.

Friedman et al. (2003) present evidence consistent with transfers of wealth from controlling shareholders benefiting public shareholders in pyramid firms. They describe both specific instances of pyramid controlling owners "propping up" firms to the benefit of their public shareholders during the Asian Crisis of the 1990s and econometric results consistent with this occurring on an economically important scale. They propose that, under some circumstances, controlling owners credibly promise to prop up distressed group firms in order to attract external debt financing. This is essentially a special case of the internal capital markets hypothesis, described above. Nonetheless, Baek et al. (2004) report that pyramid firms tightly controlled by wealthy Korean families exhibit worse stock market performance than independents during the crisis. Indeed, Graham (2003), Kang (2002), and many others document the history of scandal, political rent-seeking, and bailouts that characterizes Korean pyramidal groups.

\section{The Empirical Importance of Entrenchment Problems}

Entrenchment problems are clearly important in the United States, and are likely to be even more important in other countries. The first empirical evidence now recognized as indicative of managerial entrenchment is Johnson et al. (1985), who report that stock prices often rise significantly upon the announcement of CEO sudden deaths. This suggests that CEOs often stay in office when they might better contribute to their firm's value by retiring. They presumably do this because they enjoy private benefits of control. Morck et al. (1988) also report large and significant value discounts for U.S. firms with large shareholders, and for U.S. firms established more than thirty years ago and run by founders or their relative. They interpret both findings as evidence of managerial entrenchment. Slovin and Sushka (1993) relate the abnormal return upon 
CEO sudden deaths to the departed manager's equity stake and confirm the importance of entrenched management in narrowly held U.S. firms.

While these studies use U.S. data, and therefore refer to freestanding firms, it seems likely that similar entrenchment problems exist elsewhere. This is because the United States has a well developed corporate takeover market, sophisticated institutional investors, and litigious shareholders, all of whom are likely to work hard at dislodging entrenched corporate insiders. La Porta et al. (1998) present evidence that these pressures are almost surely much weaker in most other countries - especially Civil Law countries, in which pyramids and dominant family shareholders are generally quite important. Understanding why these differences exist, and the role of legal systems in them, would be of great value.

A low sensitivity of top manager turnover to firm performance may also indicate entrenchment. Here, evidence more directly related to family control pyramids is available. Volpin (2002) shows that, when the controlling shareholder is also the CEO, CEO turnover is largely unrelated to firm performance. Interestingly, within control pyramids, he finds that family members are replaced less often than professional managers, and that their sensitivity of turnover to performance is significantly lower than that of non-family CEOs. Brunello et al. (2003) reports a similar result - CEO turnover is elevated in poorly performing Italian firms only if the CEO is not affiliated with controlling shareholder.

Although it seems plausible that entrenchment is more pervasive in countries with more extensive family control pyramids, further work is needed to make this conclusion unequivocal. At present, we must rely on country and case studies that may not be directly comparable. For example, Filatotchev, Wright and Bleaney (1999) document Russian managers' remarkably blatant efforts to entrench themselves. De Jong and Veld (2001) argue that Dutch mangers are profoundly entrenched. Ugurlu (2000) argues that managerial entrenchment is pervasive in Turkey.

Unfortunately, comprehensive cross-country studies that could decide the matter are not yet available. Studies across large numbers of countries comparing the determinants of CEO turnover would be highly useful. Studies using data for other countries that rerun the PerezGonzales (2002) analysis of the stock price reactions to family versus professional CEO succession would also be highly useful.

\section{Valuing the Private Benefits of Control}

We argued above that entrenchment frees corporate insiders to extract private benefits of control more energetically, and that pyramids may magnify the available benefits. It is therefore useful to asses the magnitude of private benefits of control in different countries and for different sorts of firms and owners.

A way to measure corporate insiders' private benefits from control is to estimate the value the market attaches to control rights. If this value is positive, market participants believe that the controlling party obtains benefits over and above those that are shared with public shareholders. This is evidence of entrenchment. In the absence of entrenchment, these benefits would be ephemeral (and their value close to zero), for public shareholders would react by selling to a raider or supporting dissidents at a shareholders' meeting. Persistent large private benefits of control imply both a divergence of interest and insider entrenchment.

There are two ways to measure the value of control. One is to infer it from the block premium, defined as the difference between the price per share paid in a block transaction and the market price after the transaction. This premium is a lower bound on the value the acquirer 
places on control. An early example of this methodology is Barclay and Holderness (1989), who study block premiums in the U.S. Dyck and Zingales (2003) apply the same methodology across a sample of thirty-nine countries by examining 412 control transactions between 1900 and 2000 . Their results, summarized in Table 3, show that the value of control ranges from minus four percent to sixty-five percent, and averages fourteen percent of firm value. In countries where block premiums are larger, Dyck and Zingales (2003) find that capital markets are less developed, minority shareholders have fewer legal rights, and law enforcement is uncertain. Interestingly, they also find that non-legal factors, such as more diffuse ownership of the press, stronger product market competition, and higher levels of tax compliance are related to lower block premiums. Indeed, these factors have at least as much explanatory power as the legal measures.

The other method for estimating the private value of control is based on the difference between the market prices of different classes of stock. In many countries, firms have more than one class of common shares. Public shareholders invest in a class of shares, called restricted voting shares, with one or sometimes no votes per share. The controlling owner holds supervoting shares, which bestow superior voting rights. Such structures allow the controlling owner to command a majority of votes in the shareholder meeting while owning relatively few shares. Both classes of shares sometimes trade in public equity markets. Because only the shares with superior voting rights need be purchased in a sale of control, they ought to command a value premium if control provides private benefits.

This methodology has been applied to different single countries in different studies, however, this makes the results difficult to compare. ${ }^{8}$ Nenova (2003) uses this technique for eighteen countries using comparable 1997 data on 661 firms with such dual class shares. In doing this, she controls for the probability of a sale of control, block-holding costs, and dividend and liquidity differences between the share classes to estimate a lower bound on the private benefits of control. The estimates she reports, also shown in Table 3, vary from near zero for Finland, and less than $4 \%$ of firm value in Canada, Denmark, Hong Kong, Sweden, and the United States, to over $50 \%$ of firm value in Brazil, Chile, France, Italy, South Korea, and Mexico. Nenova's (2003) regressions show that the control premium is significantly lower in countries with stronger protection for outside investors' property rights, and finds that sixty-eight percent of the cross-country variation in the value of control-block votes is explained by her measures of investor rights.

The techniques of Dyke and Zingales (2003) and Nenova (2003) are potentially very useful approaches to determining private benefits of control. Much more work could be done along these lines. For instance, both studies are cross sectional. Work on how these measures vary over time in response to institutional changes, legal reforms, and the like would be of great value.

\section{Entrenchment, Private Benefits of Control, and Pyramids}

We argued above that controlling owners of pyramidal groups of listed companies are most likely to sacrifice the interests of public shareholders in firms low in their pyramids, for the controlling owner's cash flow rights in these firms are minimal. Several empirical studies present evidence consistent with such an effect.

8 See Rydqvist (1996) and Bergstrom and Rydqvist (1990 and 1992), for Sweden; Levy (1992) for Israel; Lease, McConnell, and Mikelson (1983) and Zingales (1995) for the US; Zingales (1994) for Italy, etc. 
Table 3 Estimated Private Benefits of Control in Different Countries Measured as Block and Voting Premiums and Expressed as Percentage Premium over Market Value

\begin{tabular}{|c|c|c|c|c|c|}
\hline Country & $\begin{array}{c}\text { Block } \\
\text { Premium }^{\text {a }}\end{array}$ & $\begin{array}{c}\text { Voting } \\
\text { Premium }\end{array}$ & Country & $\begin{array}{l}\text { Block } \\
\text { Premium }\end{array}$ & $\begin{array}{c}\text { Voting } \\
\text { Premium }\end{array}$ \\
\hline Argentina & 27 & & Netherlands & 2 & \\
\hline Australia & 2 & 23 & New Zealand & 3 & \\
\hline Austria & 38 & & Norway & 1 & 6 \\
\hline Brazil & 65 & 23 & Peru & 14 & \\
\hline Canada & 1 & 3 & Philippines & 13 & \\
\hline Chile & 15 & 23 & Poland & 11 & \\
\hline Colombia & 27 & & Portugal & 20 & \\
\hline Czech & 58 & & Singapore & 3 & \\
\hline Republic & & & & & \\
\hline Denmark & 8 & 1 & South Africa & 2 & 7 \\
\hline Egypt & 4 & & South Korea & 16 & 29 \\
\hline Finland & 2 & -5 & Spain & 4 & \\
\hline France & 2 & 28 & Sweden & 6 & 1 \\
\hline Germany & 10 & 10 & Switzerland & 6 & 5 \\
\hline Hong Kong & 1 & -3 & Taiwan & 0 & \\
\hline Indonesia & 7 & & Thailand & 12 & \\
\hline Israel & 27 & & Turkey & 30 & \\
\hline Italy & 37 & 29 & $\begin{array}{l}\text { United } \\
\text { Kingdom }\end{array}$ & 2 & 10 \\
\hline Japan & -4 & & United States & 2 & 2 \\
\hline Malaysia & 7 & & Venezuela & 27 & \\
\hline Mexico & 34 & 36 & & & \\
\hline
\end{tabular}

a. Block premium is average across control transactions of the difference between the price per share paid for the control block and the exchange price two days after the announcement of the control transaction, dividing it by the exchange price two days after the announcement and multiplying the ratio by the proportion of cash flow rights represented in the controlling block and expressed as a percentage premium. See Dyck and Zingales (2003), Table 2, for details.

b. Voting premium is average of estimated total vote value as a percent of firm value. See Nenova (2003), Table 5, for details.

Claessens, Djankov, Fan, and Lang (2002) examine 1996 data on 1,301 publicly traded corporations in eight East Asian economies - Hong Kong, Indonesia, South Korea, Malaysia, the Philippines, Singapore, Taiwan, and Thailand. Their sample is $37 \%$ of the 3,544 publicly traded firms in those countries. The study shows that firm value, measured by market to book ratio, rises with the cash-flow rights of the largest shareholder and falls as the control rights of the largest shareholder exceed its cash-flow rights. The latter result is especially pertinent, for the primary reason for control rights to diverge from cash flow rights in these countries is pyramidal groups. This result is thus consistent with controlling owners having less concern for maintaining the value of firms lower in their control pyramids.

Joh (2003) reexamines this issue using data from Korea, a country whose corporate sector is heavily dominated by large family controlled pyramidal groups, or chaebol. Using data on 5,829 publicly traded and private firms from 1993 through 1997, Joh finds a higher excess of control rights over cash flow rights associated with lower profitability. Again, this is consistent with controlling owners having less regard for the financial performance of firms lower in their pyramids. 
Lins (2003) uses 1995 data on 1,433 firms from eighteen emerging markets to study large equity blockholders. ${ }^{9}$ He reports that two thirds of insider controlled firms belong to control pyramids, and that insiders' voting rights average 2.7 times their cash flow rights in those firms. Regressions controlling for firm size, investment rate, leverage, and country show firm values to be depressed in proportion to the excess of insider blockholders' control rights over their cash flow rights. ${ }^{10}$ This is consistent with more pronounced agency problems in firms in lower tiers of control pyramids.

Johnson, Boone, Breach, and Friedman (2000) point out that the controlling owners' diversion of resources may depend on the anticipated future need for outside financing in each firm in a control pyramid or other group. When future investment opportunities are unexpectedly curtailed, trimming the need for internal funds, a controlling owner may prefer to siphon off the funds rather than pay them out to investors in that firm. This is a specific empirical prediction that identifies insiders' tendency to pursue self-interest while balancing against repercussions, and therefore is a rather convincing empirical test. Mitton (2002) compiles a sample of 398 firms in five East Asian countries and finds that firm performance during the 1997-1998 East Asian financial crisis - a period when investment opportunities in that region abruptly shrank - is only marginally affected by the divergence between cash flow and voting rights. However, Lemmon and Lins (2003) find a stronger result. They use a dataset of 800 firms in eight East Asian countries during the 1997-1998 financial crisis. After controlling for size, beta, debt to assets ratio, and market-to-book ratio, they find stock returns of firms in which ultimate owners control rights exceed their cash flow right to be ten to twenty percentage points lower than those of other firms. For firms in which insiders have below median control stakes, or in which the largest block holder is not an insider, performance is independent of insider's control rights relative to their cash flow rights.

The above empirical studies, which provide evidence on the relationship between entrenchment and private benefits of controls within pyramidal structures, are mostly based on East Asian countries that have relatively weak and corruption-prone institutions, at least according to La Porta et al. (1998). Unfortunately, comparable investigations using data from countries with more developed legal and other institutions, such as Western European countries, are lacking. This is an exciting area for further work.

\section{Tunneling}

We argued above that tunneling might serve as an especially effective way for entrenched controlling shareholders to extract private benefits of control. The studies discussed above that link the excess of a controlling owner's control rights over his cash flow rights to depressed financial performance or firm value are consistent with either tunneling or a simple neglect of the interests of public shareholders in lower tier pyramid firms. Direct evidence of the relative cross-country importance of tunneling is yet to be gathered. However, country studies again provide evidence that tunneling can be economically important.

The findings of Bertrand, Mehta, and Mullainathan (2002) concerning Indian family control pyramids, which they call business groups, are consistent with tunneling and are difficult to explain with any other hypothesis. They divide firms into free-standing firms, many of which

\footnotetext{
${ }^{9}$ These countries include Argentina, Brazil, Chile, Czech Rep, Hong Kong, Indonesia, Israel, Malaysia, Peru, Philippines, Portugal, Singapore, South Africa, South Korea, Sri Lanka, Taiwan (China), Thailand, and Turkey.

${ }^{10}$ Firm value creation or destruction is measured by high or low Tobin's average q, respectively. Average q is approximated by market value of equity plus book value of liabilities scaled by total assets.
} 
have controlling families, and firms belonging to family control pyramid groups. Their focal dependent variable is cash flow which is defined as earnings before depreciation, interest, and taxes over assets. Using data from 1989 to 1999 and regressions controlling for the controlling owner's cash flow rights and firm size, they find that control pyramid firms' cash flows are less sensitive to own industry factors than are those of freestanding firms ${ }^{11}$ This sensitivity to own industry factors is lower among firms in which the controlling owner's cash flow rights are lower (relative to the group median). In addition, group firms' performance is positively associated with the industry factors of other affiliates in which the controlling owner's cash flow rights are low. Interestingly, positive cash flow shocks in the lower tier firms are echoed by positive shocks in upper tier firms' cash flows, but that the converse is not true. A positive shock to a low cash flow rights firm's industry increases the cash flow for high cash flow rights affiliates about twice as much as for low cash flow rights affiliates. Thus, firms in which the controlling owner's cash flow rights are highest - that is, firms located nearest the apex of the pyramid benefit the most from a positive shock to firms elsewhere in the group. This is consistent with the controlling owner transferring net resources from low from lower to higher tier firms in the control pyramid - that is, with tunneling.

Bae, Kang, and Kim (2002) also report direct evidence of tunneling in Korean family controlled pyramids, or chaebols. Chaebol, while basically pyramidal in nature have extensive reciprocal holdings as well as simple pyramidal intercorporate ownership links. They ask whether chaebol firms benefit from acquisitions they make, or whether such benefits appear instead in firms in higher tiers of the pyramid. Using data on 107 mergers involving eightyseven firms between 1981 and 1997, they find that when one firm buys another in the same chaebol, the acquirer's stock price falls but the stocks of other firms in the same chaebol rise. The authors argue that the controlling owner typically has lower cash flow rights in the acquirer than in the target, for which the acquirer typically overpays. Intra-chaebol acquisitions thus raise wealth away from firms whose cash flows accrue more to public shareholders and up towards firms whose cash flows accrue more to controlling families. This is consistent with tunneling.

\section{E. Summary and implications}

In this section we showed that family control pyramids allow the simultaneous presence of divergence of interests agency problems, of the sort discussed by Jensen and Meckling (1976), and entrenchment agency problems, of the sort discussed by Stulz (1988). This means family control pyramids are potentially subject to worse agency problems than freestanding firms. This is because divergence of interest agency problems are most likely at their worst in widely held freestanding firms, while entrenchment problems are most likely at their worst in narrowly held freestanding firms. Lower tier firms in family control pyramids potentially suffer from both problems simultaneously. The controlling owners of pyramid firms can easily have cash flow rights as small as those of the professional managers of widely held firms, while exercising voting rights sufficient to deter any control challenge, thereby entrenching their control.

While divergence of interest and the entrenchment problems are well understood in the corporate finance literature, pyramids potentially aggravate agency problems by increasing the likelihood that firms are afflicted with both problems simultaneously.

\footnotetext{
11 Industry performance is an assets weighted average cash flow across each industry. Cash flow is profits before depreciation, interest and taxes. Each firm's industry factor is inner product of this ratio times a vector reflecting the distribution of its assets is across industries.
} 
This unwelcome reinforcement of agency problems might be especially unpropitious if less able managers who particularly value "control" become the controlling owners of pyramidal groups. Since, effectuating family control over pyramidal groups frequently involves assigning family members to key executive and board positions, and to corporate boards, corporate governance power may often be based on family ties and ability to protect the controlling family's interests, rather than ability. The overall consequence is that these firms may underperform from an asset utilization viewpoint. Finally, the lack of effective external monitoring in pyramid firms whose governance is dominated by a powerful family may deprive even scrupulous managers of effective investor feedback regarding investment decisions ${ }^{12}$.

\section{Implications of Control Pyramids}

So far, we have analyzed problems that arise in individual firms in a pyramid by focusing on the controlling shareholder's behavior. In this section, we broaden the scope of the survey and review the literature on the implications for the economy as a whole of a few old, established families controlling a substantial fraction of the economy through large pyramidal groups. This is an especially timely topic, for many emerging and transition economies are in the first stages of establishing patterns of ownership over large corporations. Intriguingly, control pyramids seem quite popular in these countries. For example, Cull, Matesova and Shirley (2002) describe Czech control pyramids. However, research on the development of pyramidal group dominance is only beginning, and much more work is needed.

We shall first describe capital allocation problems associated with established pyramids. We shall argue that, even if established pyramidal groups allocate capital efficiently internally, the overall allocation of capital across pyramidal group boundaries can still be inefficient. Moreover, this problem can be exacerbated if pyramidal groups have capital market power.

Second, extending the above arguments leads to the possibility that an economy with extensive established pyramidal structures may undertake less innovation. Because of biased capital allocation, upstarts may have difficulties raising finance; and thus invest less in innovation. Also, pyramidal group firms might invest less than is socially optimal in innovations that might compete against the current products of established group firms. Intriguingly, tunneling might actually mitigate this last effect, for the controlling owner can benefit from innovation if she can tunnel the gains towards firms in which her cash flow stake is large while leaving the negative effects of creative destruction to public shareholders.

Finally, we speculate that the prevalence of pyramidal structures is associated with an economy-wide under-supply of external capital. This speculation is based on the premise that a lack of corporate transparency reduces public investors' expected overall return. If this depresses overall domestic savings as well as the supply of capital from abroad, upstart firms' liquidity constraints could be more binding than otherwise. We hasten to reiterate that this is speculative, and that further research is needed.

All these issues point to pyramidal groups controlled by established families being associated with slow economic growth.

\section{A. Capital Allocation Problems}

We now consider how the allocation of capital across the boundaries of pyramidal groups might be distorted even though capital is efficiently allocated within each group. While this problem is

\footnotetext{
${ }^{12}$ See Durnev et al. (2004).
} 
most likely aggravated if pyramidal group controlling owners have capital market power, it can occur under competitive capital markets too.

\section{External Allocation Problems}

Almeida and Wolfenzon (2003b) propose that physical capital might be over-used within conglomerates and business groups, in that more productive applications outside of the groups are forgone. Their argument suggests that, even if physical capital is efficiently allocated within a group, the economy-wide allocation of capital might still be inefficient, in that groups have less incentive to relinquish productive assets to outside users than is socially optimal.

Their intuition is that, in an economy with poor investor protection, public shareholders rationally expect insiders to appropriate part of the return on corporate investments. Consider an economy in which some existing projects must be liquidated. A family owning such a project, and controlling no other firms, has no option but to lend the capital released in this liquidation to the outside entrepreneur with the highest productivity. However, if the family controls other firms, capital allocation can be distorted. This is because the family earns the full return when it reinvests the capital within the group; but expects only a fraction of the return when it invests in a firm controlled by someone else. Thus, the family may decide to allocate the capital within the group even if the productivity of an outsider's project is higher.

Almeida and Wolfenzon propose that the internal capital market in corporate groups may not even be a second best alternative from a social perspective. Indeed, they deduce that the more efficiently capital is allocated within a conglomerate or group, the greater the likelihood that capital is misallocated overall.

\section{Capital Market Power}

Section III.D showed that the large corporate sectors of many countries are made up of a few large pyramidal groups and scatterings of independent firms. Morck, Stangeland, and Yeung (2000) suggest that, due to their sheer size relative to the rest of the economy, large pyramidal groups might attain a degree of price setting power in their domestic capital markets.

To avoid confusing the current argument with the Almeida and Wolfenzon (2003b) argument above, we assume away all information and agency problems between lenders and users of capital. This eliminates any possibility of capital market underdevelopment due to institutional inadequacy. Now, assume that a pyramidal group has a surplus of capital so large that it has a considerable "market share" in the supply of capital. The group would supply capital for internal and external use until the two alternatives generated identical marginal returns. For an internal application, the marginal return is the simple marginal return on capital. However, the marginal return for the external alternative reflects a downward sloping capital demand schedule, which is the external users' marginal return on capital. The marginal return of capital in an internal application is thus less than the external users' marginal return. In other words, the group provides too little capital to external users at too dear a price.

Along this vein, additional considerations arise. First, outside investment might erode the controlling owner's capital market power, as outsiders accumulate wealth from their investments. Hence, when supplying capital to external users, a thoughtful controlling owner considers this negative effect, which is absent when supplying capital to internal users. This should induce group firms to charge external users of capital more than internal users. Second, gradations might arise in the cost of capital within the pyramid related to the controlling owner's cash flow rights in each firm. 
In the alternative case, where the pyramidal group has insufficient capital for its internal needs, its sheer size could give it monopsony "market power" in the sourcing of external capital. This, through a precisely symmetric set of arguments to those outlined above, induces the group to use too little capital and to pay too low a rate of return to the providers of external capital.

\section{Relationship Banking Problems}

Pyramidal groups often contain major commercial, investment, merchant, or universal banks as member firms. For example, one branch of the Canadian Bronfman family controls Hees International Bancorp, a large merchant bank, and the Swedish Wallenberg family controls SEB, a large Swedish universal bank. Sharing a controlling owner presumably lessens information asymmetry problems between borrower and lender firms, and so allows firms in a pyramidal group preferential access to bank financing. This is a further extension of the above idea of business groups allocating capital among their member firms at low cost relative to alternative allocation mechanisms. Having a bank as an integral part of the group's structure is not always necessary, for the apex firm can serve as a de facto bank in any event. Regardless, it is instructive to consider the implications of group banks within the framework of the relationship banking literature.

A borrower having a relationship with his bank mitigates information asymmetry problems and thus eases liquidity constraints, as in Peterson and Rajan (1994). However, Rajan (1992) also shows that such a relationship locks a borrower into a long-term bond with its bank. This is because, once the relationship is established, switching banks sends a negative quality signal about the borrower to other prospective lenders. This makes the borrower vulnerable to "hold-up problems". If the bank and borrower firm are in the same control pyramid, and so have the same ultimate owner, both information asymmetry and hold-up problems might be mitigated.

Even if the bank is not a member firm of the pyramid, these considerations might still remain. The share of the rent arising from the relationship that the bank captures depends on the outside opportunities and respective market power of both the bank and the borrower. For example, a larger borrower with more outside financing alternatives should be able to keep a greater share of the relationship rent. Likewise, if the bank's profits are more dependent on retaining the pyramid firms as borrowers, its share of relationship rent falls. Family control pyramids containing more corporate assets ought thus to be better able to retain relationship rents than smaller stand alone firms.

In either case, pyramid firms would enjoy cheaper access to capital, all else equal. Indeed, banks might appear to discriminate against freestanding firms.

\section{Empirical Evidence}

At present, little empirical work examines capital allocation within and between family controlled pyramidal groups, or capital allocation across group firms and freestanding firms. Morck, Stangeland, and Yeung (2000) report that Canadian firms controlled by old money families have elevated capital-labor ratio after controlling for industry, firm size, and firm age. Consistent with this, Attig, Fischer and Gadhoum (2003) find that Canadian firms affiliated with pyramidal groups have greater capital expenditures than comparable non-affiliated firms. Moreover, the higher the controlling owner's cash flow stake, the more elevated the capital expenditure.

The monopsony case discussed above can probably be eliminated as a description of the Canadian economy, for it predicts, at least in its most naïve form, that group firms ought to use 
less capital than other firms, which is not observed. However, any or all of the other capital allocation distortions might be occurring in that country.

Further work on other countries is also clearly needed for potentially valid a priori arguments can lead in either direction. For example, Khanna (2000) argues cogently that the Tata pyramidal group of India is social welfare enhancing because it substitutes for imperfect capital markets in that country and thus allows entrepreneurs to obtain financing that would otherwise be unavailable. This has to be pitched against the Almeida and Wolfenzon (2003b) argument that groups may inefficiently concentrate capital. The nature of pyramidal groups' effects on the allocation of capital is thus, in the final analysis, an empirical issue.

Consequently, further empirical investigation along these lines is likely to be quite interesting. The relative capital intensity of pyramidal group versus freestanding firms in other countries is not known. Likewise, studies comparing levels of internal utilization of retained earnings in pyramidal groups versus freestanding firms would be highly useful. Finally, and perhaps most difficult, evidence on macroeconomic capital intensity and reinvestment of earnings across economies with different incidences of old, established family groups would be desirable. Each of these exercises would, of course, require an "all other things equal" baseline. This means further thought is needed regarding necessary controls beyond the obvious ones, such as industry, and time fixed effects.

\section{B. Depressed Investment in Innovation}

Innovation is an especially interesting type of investment in an economy of control pyramids. Schumpeter $(1912,1942)$ is now generally acknowledged as correct in arguing that growth is a process of creative destruction. Growth requires the continual creation of innovations based on new technology or a recombination of old technologies, with technology broadly defined to include scientific, managerial, and other practices important to a firm. Yet, innovations also cause the destruction of firms built around activities rendered obsolete. Schumpeter (1912) points out that innovators seldom have access to large flows of retained earnings, and that innovation consequently usually requires outside financing. This suggests that innovation ought to depend on the existence of functional capital markets and institutions, a hypothesis empirically verified by King and Levine (1993). Alternatively, Schumpeter (1942) proposes that large firms with ample cash flows from previous investments might best be able to finance innovation. More broadly, innovation requires that innovators have access to capital.

Morck et al. (2000) develop a special case of this argument. They argue the destruction intrinsic to innovation is often an externality to a freestanding firm, but that this is less likely for a large control pyramid. In an economy of freestanding firms, a maker of superior plastic pipes, who takes business away from copper pipe makers, bears none of the costs associated with the declining copper industry. Even if some investors hold stocks in both businesses, competition between investors insures that the plastic pipes venture can be financed as a stand alone entity. In an economy of control pyramids, where the copper pipe maker and plastics company have the same controlling shareholder, financing for the plastic firm's innovation may be less forthcoming. The controlling shareholder may see little net advantage in letting her plastics company disrupt her copper company. Morck et al. (2003) call this problem creative selfdestruction. $^{13}$ Even if the plastics firm is not part of a group, the controlling owners of pyramidal groups containing steel companies might exert whatever capital market power they

\footnotetext{
${ }^{13}$ In a somewhat similar vein, Acemoglu and Robinson (2002) argue that elites historically sometimes blocked new and efficient technologies to avoid changes that threatened their political power.
} 
command to deny financing to the upstart plastics maker. Certainly, the controlling owner has little incentive to cooperate with the innovator to form a commercial alliance, and might even seek to expropriate the innovation to slow the pace of its application.

Intriguingly, tunneling within pyramidal groups might actually mitigate the problems associated with creative self-destruction. This is because creative destruction might proceed apace if the controlling shareholder can tunnel away profits from the creative innovation and leave public shareholders to absorb the costs of the "destruction" of firms with obsolete technology. Thus, freer tunneling might actually reduce dynamic inefficiencies. Thus, stronger public shareholder rights might impede innovation by curtailing tunneling, but might also accelerate innovation by deepening financial markets, which King and Levine (1993) argue lets entrepreneurs establish new firms to develop their innovations. Thus, while family control pyramids ought to be related to a slower pace of innovation, the interaction of this effect with stronger public shareholder rights is difficult to predict.

Finally, it is important to note that the above need not apply to all pyramidal or other

groups. For example, De Long (1990) argues that the J. P. Morgan group in the late $19^{\text {th }}$ and early $20^{\text {th }}$ century United States was instrumental in financing numerous innovative ventures, and in lending its financial credibility to entrepreneurs. Empirical work is needed to determine which outcome is more economically important and under what circumstances.

Only the most preliminary empirical work tests these ideas. Morck et al. (2000) report that firms controlled by old, established Canadian families spend less on R\&D than other Canadian firms and than similar US firms, controlling for industry, firm size, and firm age. They also report that countries with larger billionaire inherited wealth over GDP have lower private sector R\&D spending. Given the importance of innovation to economic growth, further work on the investment policies, $R \& D$ strategies, capital intensity, and liquidity constraints of firms with different ownership structures is clearly a priority.

\section{Overall Capital Market Effects}

So far, the discussion in this section has focused on firm-level effects regarding capital access and investment decisions. However, these firm level effects might easily attain macroeconomic proportions in economies where a few old families control the greater part of the corporate sector. Also, by affecting the nature of capital markets, extensive pyramiding might directly affect macroeconomic outcomes.

For example, a prevalence of pyramidal groups in a country's corporate sector might render the average firm more opaque to outside investors, both domestic and foreign, and this might induce both to place their savings elsewhere. This might be a direct effect, arising out of the increased complexity of accounting in large groups of firms. It might also be indirect, in that the controlling owners of large pyramidal groups might press government officials to maintain ineffective shareholder protection and weak disclosure rules to better facilitate tunneling.

The opacity of business groups could have macroeconomic implications through reduced liquidations of low productivity firms. Kim (2004) shows that a bank has more difficulty inferring the quality of members of a business groups than of stand alone firms, after observing loan payments. This is because inter-group loan guarantees prevent the bank from knowing whether the payment is from the borrower or from other firms in the group. Consequently, the bank is more likely to liquidate a freestanding firm than an otherwise identical group firm.

These admittedly entirely speculative hypotheses suggest testing whether or not a high prevalence of pyramidal groups relates to an under-supply of external capital in an economy. 
Moreover, how severely liquidity constraints impede the growth of upstarts might depend on the precise mechanism involved. If pyramids per se render their member firms more opaque, freestanding firms might be at an advantage in raising external capital. However, if controlling owners press for weak institutions, this might especially constrain upstart firms. Weak investor legal rights and poor disclosure ought conceivably to make it harder for good upstart firms to signal investors about their quality.

Along these lines, Shleifer and Wolfenzon (2002) argue that the misappropriation of wealth by controlling shareholders raises overall costs of capital to the corporate sector, and thus impedes growth. Lombardo and Pagano (2002) argue that aggravated information asymmetry problems in economies with weak institutions move demand and supply schedules for capital so as to reduce both the aggregate amount of capital used and social welfare. Castro Clementi, and MacDonald (2003) propose that strengthened property rights for public investors can have a twofold effect. On the one hand, stronger legal rights raise public investors' level of trust and so lower the cost of capital to entrepreneurs. On the other hand, stronger investor property rights reallocate wealth from controlling families to the middle classes. If ordinary investors have a lower propensity to save, this might actually reduce the overall level of savings in the economy. Castro, Clementi, and MacDonald (2003) develop an overlapping generations model that magnifies the latter effect by positing that stronger investor rights reallocates capital from the younger generation of entrepreneurs to the older generation of retirees, and that the latter have a minimal propensity to save.

Empirical work to test these theories, and to develop stylized facts within which future theories in this are must fit, is clearly important.

\section{Summary}

This and the previous section show that the effects of control pyramids on corporate governance might well be especially injurious in countries that provide public shareholders ineffective legal rights against malfeasance by corporate insiders. These governance problems, allowed free reign, plausibly retard macroeconomic performance for three reasons. First, the adverse effects of a single poor manager become a macroeconomic problem if she controls a pyramid that includes a substantial fraction of a country's corporate assets. The structure of a control pyramid also leads to a variety of capital allocation distortions. By altering the overall investment level and by skewing the distribution of capital expenditure across groups, firms, and projects; these distortions can compromise economic growth. Second, control pyramids might adversely affect investment in innovation because they cause an internalization of the disruptive effects of one firm's innovation upon another. This, especially, might be a powerful growth retardant. Third, the concentration of capital within pyramidal groups may negatively affect public investors' required returns because of the opacity of control pyramids. The distribution of returns to different classes of investor may also affect the overall supply of savings because of difference in their propensities to save.

The regulation of capital markets and institutions in general, and of corporate governance in particular, are ultimately functions of a country's political process - see e.g. North (1991). We therefore turn to the interaction of control pyramids with political economy in the next section. 


\section{Political Economy Considerations}

While inequality exists in virtually every country, we showed above that control pyramids can magnify large inequalities in wealth into truly enormous inequalities in economic power. Control pyramids effectively entrust the corporate governance of the greater parts of the corporate sectors of many countries to handfuls of elite, established families, who can quite reasonably be described as oligarchs. The extent to which this concentration of corporate governance power occurs can be used to arrange capitalist economies along a metric with two stylized endpoints. One endpoint, diffuse capitalism, best approximated by the United States and United Kingdom, is characterized by numerous professionally managed freestanding large corporations, each owned by small investors whose property rights are well protected by effective laws. The other endpoint, oligarchic capitalism, approximated by most East Asian and Latin American economies, is characterized by public investors holding minority voting stakes in large corporations that are controlled by a few families through control pyramids.

In this section, we consider this metric more closely in a framework of political economy, the discussion of which we have postponed until now. We propose that oligarchs have strong incentives to lobby politicians and public servants for policies that preserve the status quo. These policies include the limitations on public investors' rights discussed in the previous section, as well as high barriers to entry and international trade and capital barriers. We propose that these policies can best be thought of as political economy outcomes due to the relative strength of oligarchs' political influence.

Political influence by oligarchs, then, leads to policies that preserve and expand their corporate governance power, which preserves and expands the resources at their disposal for further political lobbying. We argue that this self-sustaining feedback loop makes oligarchic capitalism highly stable.

Although the extreme concentration of corporate governance power characteristic of oligarchic capitalism may seem undesirable per se to some, it might nonetheless be economically efficient. We argue that this is unlikely because the weak shareholder rights, barriers to entry, and trade and capital flow restrictions often associated with oligarchic capitalism are known to be associated with poor long-run macroeconomic performance. Indeed, these problems may well explain why Morck et al. (2000) find that economies with larger inherited wealth post slower growth.

Finally, the concepts we develop in this section is really quite general. Although we focus on family control pyramids, the broader issues - who allocates capital and how hard it is to replace them - can attain macroeconomic importance under certain institutional arrangements. Family control pyramids are one such arrangement. But the professionally managed keiretsu groupings of Japanese corporations might be another, as Morck and Nakamura (1999) argue. Yet another might involve an entrenched elite of bureaucrats presiding over inefficient stateowned enterprises, as in Krueger (1993). See also Megginson and Netter (2001).

\section{A. Economic Entrenchment}

We define an economy as exhibiting economic entrenchment if it has a highly oligarchic flavor of capitalism and exhibits signs of enduring economic inefficiency. ${ }^{14}$ Thus, oligarchs who allocate resources economically efficiently do not qualify as entrenched. Likewise, temporary

\footnotetext{
${ }^{14}$ Note that this is deliberately distinct from managerial entrenchment in corporate finance, where suboptimal managers cannot be ousted and the performance of the firm suffers. We view economic entrenchment as a macroeconomic counterpart to this, and a potentially much more important problem.
} 
economic inefficiency, due to poor government policies or poor corporate governance that are soon corrected, is also not indicative of entrenchment. We envision economic entrenchment as characterizing oligarchic capitalist economies that exhibit a sustained inefficient use of resources - and of capital in particular - that benefits vested interest at the expense of the rest of the economy.

There are many possible reasons why oligarchic capitalism might allocate resources more or less efficiently than diffuse capitalism. If the oligarchs are especially adept at business, they may excel at placing resources where their values are highest. Indeed, this might underlie the finding of Morck et al. (2000) of high growth in countries in which great wealth is concentrated in the hands of self-made billionaires. But if oligarchs were poor managers, the concentrated corporate governance in oligarchic capitalism could magnify the mistakes of a few individuals into macroeconomic problems.

Wurgler (2000) shows that sound capital institutions and markets, especially shareholder legal rights, effectively check capital misallocation - presumably including that by corporate insiders running control pyramids. He measures the quality of capital allocation by the propensity of capital to flow to high value-added sectors, and demonstrates a strong positive correlation between this variable and measures of public shareholders' legal rights against corporate insiders. The measure of public shareholders' rights he uses is from La Porta et al. (1997b, 1998), who add up distinct legal rights - the right to vote by mail, the right to sell shares prior to meetings, the right to cumulative voting, the right to sue directors, pre-emptive rights to new issues, and the right to call extraordinary shareholder meetings.

The "Law and Finance" literature, which descends from La Porta et al. (1997b, 1998), argues more broadly that how well capital markets function depends on a range of customs, rules, laws, and regulations, and on how vigorously they are enforced. Thus, statutory shareholder rights are largely meaningless if the judiciary, police, and regulators are all deeply corrupt. While legal rights for public shareholders are clearly an important determinant of how well capital is allocated, other considerations factor in as well. These include a general absence of corruption, transparent accounting and disclosure, and many other dimensions of institutional development. Ultimately, a pervasive respect for outsiders' private property rights seems basic to an efficient allocation of capital.

This respect must engender not only rights for public investors, but also rights for aspiring entrepreneurs. Djankov, La Porta, Lopez-de-Silanes and Shleifer (2002) document the difficulties entrepreneurs confront in becoming registered business firms in many poor countries. These include expensive, arbitrary, and repeated inspections, taxes, and fees relating to "safety and health," the environment, labor, and "screening." They show that the time and direct cost of these procedures as a fraction of 1999 per capita GDP, as well as their sheer number, is significantly positively correlated with measures of government corruption. Such arbitrary barriers to entry deter prospective entrepreneurs and lock in control by insiders. We count such impediments as infringements on entrepreneurs' private property rights.

For expository convenience, we refer to all of these rights together as private property rights. The degree to which the private property rights of public investors and entrants are protected, both from the government and from more powerful individuals, depends on government policies - their stipulation and enforcement. Although economics long regarded government policies as exogenous except in limited areas - such as taxes, monetary policy, and fiscal policy - recent work, such as Krueger (1993), Olson (1982, and 2000), favors treating 
government policies as thoroughly endogenous; in particular, they depend on political influence, or lobbying. ${ }^{15}$

The "law and finance" literature discussed above points to a clear importance of countries' legal systems in explaining the development of their financial systems. Further work is needed to understand the operational nature of this effect, as well as the historical interplay of individual countries' legal systems and economies. Extending this literature, determining its limitations, and filling in its missing pieces are all attractive areas for further theoretical and empirical work.

\section{B. Political Influence in Oligarchic Capitalist Economies}

There are a number of reasons for believing that oligarchic families are likely to be highly effective political lobbyers, especially when they control large pyramidal groups of companies. In particular, Morck and Yeung (2003) argue that the apex shareholders of control pyramids have particularly low political lobbying costs.

One reason they stress is that the controlling owners of great pyramidal groups command vast economic resources, from which they can readily make up-front side payments to public officials. In contrast, new entrants, usually short of capital, must promise future side payments for advantageous government policies now. Since many new ventures fail, or are taken over by others, such promises are risky investments for a public official. Thus, the controlling owners of great pyramidal groups have lower lobbying costs than the principals or professional managers of new entrants have.

A second set of reasons has to do with lower transactions costs. The controlling owner can pool the resources of many companies to make side payments to politicians without the coordination costs a similar array of freestanding firms would incur. An array of freestanding firms would also surely experience some free-rider problems, while an array of pyramid firms with a common controlling owner need not.

Moreover, Olson (1982) argues that larger or more diverse groups of people have higher transaction costs in organizing effective lobbying. Control pyramids concentrate corporate governance rights over vast sweeps of many countries' economies among handfuls of wealthy families. The number of oligarchs is small and the transaction cost of coordinating their actions is correspondingly low. This makes coordinating the lobbying of different oligarchs easier.

Yet another reason oligarchs' transactions costs might be low is that politicians might perceive them as more trustworthy partners in favor trading. Favor trading between political and corporate insiders often involves trading actions today for promised future responses. The beneficiary of today's action has an ex post incentive not to pay up. The C.E.O.s of widely held firms in the United States last an average of seven years on the job - an eye blink compared to the permanence of the old money families controlling corporate pyramids in many countries. One CEO of a widely held firm may feel little obligation to uphold promises made by a predecessor. In contrast, a dynastic family can better keep faith over time. Likewise, an oligarch should discount promised future consideration from a public official at a lower rate than the

\footnotetext{
${ }^{15}$ For example, Krueger (1993) argues that import substitution programs generate groups which include bureaucrats, firms, and individuals whose fortunes grow under the programs, and who gain political power, and then defend the programs to protect their vested interest. The result is a vicious cycle of poorer and poorer economic growth. She pitches that against a virtuous cycle in which export oriented program breeds defenders of export oriented policies and economic growth gets better and better. She advocates paying attention to the political-economics dynamic interactions.
} 
professional manager of a widely held freestanding firms would use. Finally, officials should be less willing to break faith with the controlling owner of a great pyramidal group, for she would have means to "punish" the defecting official, given her extensive corporate governance powers. Thus, the controlling owners of pyramids have lower lobbying costs than the professional managers of widely held freestanding firms.

A third set of reasons why oligarchs' lobbying costs are likely to be especially low involves their use of tunneling to transfer resources among controlled firms. For example, the controlling owner could trade payments to politicians from lower tier firms for favors that benefit higher tier firms. In this way, public shareholders pay the group's lobbying costs while the controlling family reaps the benefits of lobbying. That is, the controlling owner need sacrifice personal or family wealth equal to only a small fraction of the actual side payments. By coordinating where the costs and benefits of political rent-seeking fall among pyramid firms, the controlling owner can effectively tunnel wealth from one firm to the other without directly transferring assets or income between firms. Moreover, to render favors to government officials, the controlling family of a pyramid can tunnel resources to where the payment can be made most discretely - perhaps a private firm or a firm in an industry with little government business. That means constraints on the specific form favors to officials can take are less restrictive for oligarchs than for the principals or managers of freestanding firms.

Finally, corporate insiders and political insiders may be the same people, or at least from the same families. This may be the result of effective past lobbying, but it surely also facilitates further cooperation between oligarchic families and the State.

Such ties are surprisingly prevalent. Claessens, Djankov, and Lang (2000, p. 109), citing the New York Times (Sept 8 1998, p. 2) report that "the business empire of the Suharto (the previous strong man in Indonesia) family is thought to control 417 listed and unlisted companies through a number of business groups led by children, other relatives, and business partners, many of whom also have held government offices" and describe how Imelda Marcos, the widow of former Philippines president Ferdinand Marcos, explains that her relatives "practically own everything in the Philippines from electricity, telecommunications, airlines, banking, beer and tobacco, newspaper publishing, television stations, shipping, oil and mining, hotels and beach resorts, down to coconut milling, small farms, real estate and insurance" (Financial Times, Dec 8, 199, p. 16). The Chief Executive of Hong Kong was the offspring of a shipping tycoon, and Kashing Li, who controls some large pyramidal groups, allegedly maintains a considerable stake in the Chief Executive's family business. The Lee family provided Singapore a head of state for decades, while also managing many of its businesses. The Appendix to Johnson and Mitton (2003) describes the close ties of the Mahathir family, Daim Zainuddin (a previous finance minister) and Anwar Ibrahim (a purged vice prime minister) with Malaysian businesses. Former Russian Prime Minister Viktor Chernomyrdin is a large shareholder of Gazprom. Faccio (2003) provides other abundant examples.

Nor are such connections restricted to emerging market countries. Faccio and Lang (2002) report that two members of the Agnelli family, which controls the largest Italian industrial group, serve Italy as members of parliament. Silvio Berlusconi, who controls another of the same country's largest pyramidal groups, serves Italy as Prime Minister. And Francois Pinault, the controlling shareholder of Pinault-Printemps-Redoute, Grand Bazar de Lyon, Rexel, and Zodiac, is reputedly a close friend of French President Jacques Chirac. ${ }^{16 .}$ Paul Desmarais, the controlling shareholder of one of Canada's largest pyramidal groups, is also a closely related

\footnotetext{
${ }^{16}$ About on going stories, see, e.g., Financial Times, Dec 6, 2003, "Heat on Chirac for Public Inquiry."
} 
in-law of former Prime Minister Jean Chrétien and the longtime business associate of the current Prime Minister, Paul Martin.

Faccio (2003) examines these relationships formally by carefully documenting family ties between the political and corporate leaders of forty two different countries. She reports that firms representing $7.76 \%$ of the world's market capitalization are run by relatives of their countries' political leaders. While there is no hint of corruption in many of these family ties, others presumably result from political influence and lower the costs of further lobbying.

Indeed, political influence might be instrumental to owners' private benefits of control. Faccio (2003) shows that, after controlling for endogeneity, politically connected companies enjoy easier access to debt financing, lower taxation, and higher market shares. She also demonstrates that announcements of directors or dominant shareholders entering politics or of politicians joining boards result in a significant increase in firm value when companies operate in highly corrupt countries. De Soto (1989), Shleifer and Vishny (1993, 1994), and others argue that such political connections give firms preferential access to government subsidies, financing from government owned enterprises and banks, tax breaks, and exemption from burdensome regulations.

This is not to suggest that political lobbying is an unimportant corporate investment in diffuse capitalist economies like the United Kingdom and United States. A huge literature, in its modern form descending from Stigler (1971), attests to the near universal importance of political rent-seeking. Indeed, many of the arguments listed above suggest that large family firms might also have a political rent-seeking advantage in diffuse capitalist economies. For example, the Financial Times (Feb. 26, 2004, p. 8) quotes a "former US government trade official" as being impressed with Cargill, a huge private US family agribusiness because "They weren't simply looking in a short sighted way at the bottom line, but had an eye on the longer term. It made me more and more inclined to listen to them for trade negotiations." Econometric evidence on which sorts of firms are best at political rent seeking is scant. ${ }^{17}$

Our point here is not that diffuse capitalism is free of political rent-seeking, but that oligarchic capitalism, because of pyramidal corporate control and the other factors described above, narrowly concentrates and greatly magnifies political rent-seeking power in the hands of a tiny elite.

Furthermore, Morck and Yeung (2003) show that there is a strong correlation between corruption and family control. Using 1995 family control data from La Porta et al. (1999) and indices about corruption, they produce the following table.

Extensive lobbying power in the hands of a country's leading business families might seem a recipe for strong private property rights, but Morck et al. (2000), Glaezer et al. (2003) Rajan and Zinglaes (2003), Sonin (2003), and others argue that this is far from clear. Glaezer et al. (2003) posit that the very wealthy can prefer weak property rights when they benefit from the transfer payments that weakness allows. Shleifer (1997) points out that, in economies with poor general property rights protection, the wealthy often invest in private protection of their property rights. If this has a fixed cost, the wealthy prefer continued private enforcement of their property rights and an absence of property rights protection for others.

\footnotetext{
${ }^{17}$ Though see Lenway et al. (1996).
} 
Table 5 Measures of the Return to Political Rent Seeking and the Incidence of Family Firms

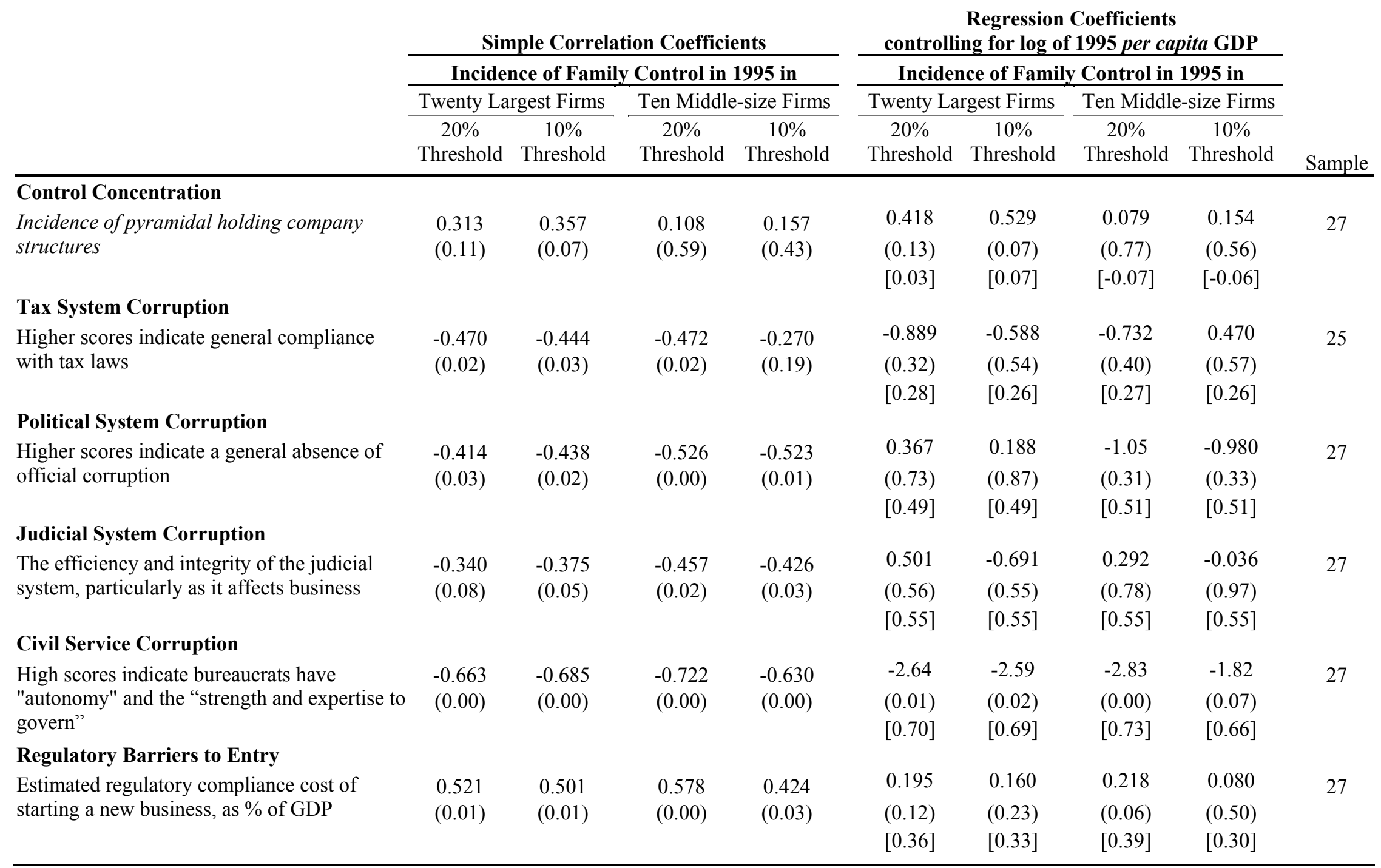

Numbers in parenthesis are probability levels for the null hypothesis of a zero simple correlation or a zero coefficient on oligarchic family control in regressions of each rent-seeking variable of that variable and the logarithm of 1995 per capita GDP. Numbers in square brackets are regression adjusted $R^{2}$ statistics. 
Entrepreneurial ability, like other dimensions of intelligence, is likely to be at most only partially hereditary. On average, the entrepreneurial ability of oligarchic family scions ought to regress steadily towards the population mean with each successive generation, as modeled by Caselli and Gennaioli (2003). Yet an oligarch with little entrepreneurial ability still commands all the political lobbying advantages enumerated above. Thus, older billionaire families should be progressively more drawn towards using political influence, rather than entrepreneurship, to sustain their economic positions. Sonin (2003) makes an argument in connection with transition economies that parallels ours in some ways. A first generation of entrepreneurs in many transition economies became wealthy through adept rent-seeking, rather than genuine entrepreneurship, and therefore favors weak general property rights enforcement because this facilitates their continued rent seeking.

By using their political influence to lock in their own corporate governance power, economically entrenched oligarchs thus also lock in on-going suboptimal capital allocation. This is partly because hereditary oligarchs are simply likely to possess limited ability as entrepreneurs. In part, it also reflects the corporate governance problems intrinsic to the control pyramids that provide oligarchs with vast rent-seeking influence. It also reflects the incentives oligarchs have to suppress innovations that threaten the value of their existing capital that were discussed in the previous section. And the lobbying for entry barriers and the like that lock in oligarchs' governance powers can also have side effects that further distort capital and other resource allocation.

\section{Formalizing the Flavors of Capitalism}

We argued above that different countries apply different versions of capitalism, ranging from the oligarchic capitalism of many Latin American countries to the diffuse capitalism of the United States and United Kingdom. In the previous section, we proposed that oligarchs in the former version of capitalism might use the political process in their countries to entrench themselves. In this section, we formalize this reasoning.

Wealthy families might lobby for stronger private property rights, including shareholder rights that promote financial development. ${ }^{18}$ We take financial development to mean greater functional form efficiency of the financial system, as defined by Tobin $(1982)^{19}$. Intuitively, a more developed, or more functionally efficient, financial system is one that better allocates capital to its highest value uses. Greater financial development would let wealthy families sell out, or raise outside capital, on more advantageous terms. But wealthy families might also lobby for institutions that enhance and protect their private benefits of control, weakening the private property rights of others and retarding financial development. Public investors, in contrast, unambiguously prefer strong private property rights protection since the main effect of weak rights is worse predation by oligarchs. Potential entrepreneurial entrants likewise prefer strong private property rights because this lets them raise funds from public investors on better terms.

\footnotetext{
${ }^{18}$ We deliberately adopt a narrow view of property rights related to financial development; however, a broader view may also be sensible. For instance, a class of top professional managers might become "entrenched" by setting up takeover defenses and undermining shareholder democracy. Or, as Krueger (1993) argues, government activism might lead to the development of a class of bureaucrats that "entrenches" to preserve its influence and economic power. Of course, large interventionist government, pursuing social objectives other than economic efficiency, might deliberately sacrifice investors' property rights and financial development to those ends - even without entrenched bureaucrats. If these other forms of entrenchment, or big government per se, are correlated with family control pyramids, this could confound the framework we develop below.

${ }^{19}$ Levine (1997) gives a more extensive list of the functions of financial markets: mobilizing savings, allocating resources, exerting corporate control, facilitating risk management, and easing trade in goods, services, and contracts. Tobin's definition is more in line with this survey's focus.
} 
Whether economic entrenchment ensues or not thus depends upon which way the oligarchs opt. Moreover, since we showed above that oligarchs likely have vastly more lobbying power than other segments of the economy, their wishes may well predominate in public policy discussions.

\section{Conceptual framework}

This can be formalized somewhat, along lines developed in Shleifer and Wolfenzon (2002). Public shareholders expect some "stealing" by corporate insiders, so external financing is more expensive than internal financing. Thus, an entrepreneur seeking external financing must compensate investors for her expected thievery up front, in the form of a low share price in the initial sale of equity to the public. Consequently, the entrepreneur uses internal cash if possible, and considers external financing only to top this off when necessary. Better private property rights reduce actual and expected thievery by insiders, and thus reduce the cost of external capital. This makes more investment projects viable for entrepreneurs. The result is faster economic growth.

The level of private property rights is controllable by the government - either by altering the rights on the books or by varying the enthusiasm with which they are enforced. This means the government can determine capital market functionality. By raising the level of private property rights, it can therefore generate faster economic growth.

Consider a simple stylized political economy model with the following cast of players: First, there are political insiders who value both economic growth and side payments. The side payments can be outright bribery, campaign contributions, or anything in between. Second, there are corporate insiders, who control on-going business operations with considerable internal cash. Third, there are outsiders, who include both public investors and potential innovative entrepreneurs. We assume the political insiders and corporate insiders each act as one. In contrast, there are a very large number of outsiders, each with a small amount of cash, who cannot act collectively. Outsiders supply their savings to capital users competitively. Some outsiders wish to become entrepreneurs, and are possibly more able that the corporate insiders currently entrusted with corporate governance.

Consider a bargaining equilibrium among political insiders, corporate insiders, and potential entrepreneurial entrants. For simplicity, suppose there are only two levels of private property rights: strong (S) and weak (W). The maximum side payment the corporate insiders are willing to pay to the political insiders is the difference between their wealth in states $\mathrm{W}$ and $\mathrm{S}$. An analogous constraint applies to each outsider. This is a minimally binding constraint for the corporate insiders, for pyramids might allow them to use assets they control, rather than their own wealth, to pay bribes. The political insiders' utility is a weighted average of the side payments received and economic growth, which is higher if shareholder protection is strong.

Define an equilibrium as a level of private property rights such that

1. The political insiders' utility at the equilibrium is higher than at the other level.

2. Neither the corporate insiders nor the outsiders are willing and able to pay side payments to the political insiders sufficient to induce a change in the private property rights regime.

If the corporate insiders lobby for strong private property rights, they can sell their capital assets to more able entrants, who can more readily raise the necessary funds from public investors. This permits the old corporate insiders to fade away into a comfortable retirement. Moreover, as strong private property rights are implemented, the value of private benefits of control, including those due to pyramids, falls. This limits corporate insiders' ability to make side payments, and thus limits their political influence, reinforcing their decision to sell out. (Assuming side payments are 
financed out of current cash flow.) All of this combines to create pressure towards less oligarchic and more diffuse capitalism.

In contrast, if the corporate insiders lobby for weaker property rights, and the attendant higher private benefits of control, they set the stage for economic entrenchment. Policies that compromise investor rights raise oligarchs' private benefits of control, providing them with more resources to lobby further. This presumably results in pressure towards more oligarchic and less diffuse capitalism.

This example is highly simplified in that it allows only two levels of private property rights protection, $\mathrm{S}$ and $\mathrm{W}$. In fact, private property rights protection is a multidimensional phenomenon that certainly can take more than two values. However, two values suffice to make our basic point: Economic entrenchment is but one possible equilibrium. There can be others - perhaps many others - in a more nuanced model. This suggests that previous work, such as Morck et al. (2000) and Rajan and Zingales (2003), may be excessively pessimistic in focusing too single-mindedly on the weak shareholder rights equilibrium. Nonetheless, that work clearly captures important aspects of the political economies of many countries, especially those that entrust corporate governance to pyramids controlled by a few old moneyed families.

Establishing the equilibrium is non-trivial. However, some intuitive considerations must apply. Any deviation from a pre-existing level of private property rights has several effects:

1. Any improvement in private property rights transfers wealth from existing users of capital to existing providers of capital. The opposite occurs if private property rights fall. We call this the transfer effect.

2. Any improvement in private property rights reduces the cost of external capital, and thus raises capital investment by both corporate insiders and outsider entrepreneurs. The opposite is true when private property rights are downgraded. We call this the cost of capital effect. The cost of capital effect is positive for outsiders when private property rights are strengthened and negative when they are downgraded. For corporate insiders, the cost of capital effect from stronger private property rights is positive if they need outside capital and zero if they do not. The cost of capital effect for corporate insiders from reduced private property rights protection is negative if they have insufficient internal capital, but zero if they need no external funds.

3. A change in private property rights changes the number of outsiders who become entrepreneurs and undertake investment projects. This is because stronger private property rights lower their costs of external capital and make more projects viable. This creates product market competition for the firms controlled by corporate insiders. It also creates capital market competition, as today's entrepreneurs have more wealth to invest in the future. And it allows creative destruction to proceed, which erodes the value of the corporate insiders' existing capital assets. This competition effect is negative for corporate insiders if private property rights grow stronger, and positive if they grow weaker.

These considerations belie any simple predictions about the relationship between the level of private property rights and the corporate insider's welfare. Morck, Stangeland, and Yeung (2000) and Rajan and Zingales (2003) assume that weaker private property rights always benefit the corporate insider. That is, they presume that the transfer, cost of capital, and competition effects combine to generate a net increase in the corporate insider's welfare when the private property rights regime switches from $\mathrm{S}$ to $\mathrm{W}$. This is likely a special case, albeit an important one, for the sum of 
the effects can be the opposite. For example, if corporate insiders' future investment needs greatly exceed their internal cash, the cost of capital effect might be sufficiently negative to overwhelm the positive transfer and competition effects. In this case, the corporate insiders and the outsiders concur on the need for stronger private property rights.

Rajan and Zingales (2003) point out that many countries that currently have small stock markets had large and dynamic stock markets a century ago - a phenomenon they call the great reversal. They propose that, in these countries, a first generation of corporate insiders raised money from public investors and then lobbied for policies that caused financial market atrophy, or at least stood by while ideologues enacted them. This weakening of private property rights was to their advantage because they no longer needed outside capital. In our terminology, the "cost of capital" effect faded, and the "transfer" and "competition" effects dominated. They call their idea an interest group theory of financial development, which parallels our concept of economic entrenchment. In essence, Rajan and Zingales (2003) propose that the preferences of the first generation of corporate insiders regarding investor property rights protection changed as the insiders aged - or that their heirs had markedly different preferences.

This reasoning, while perhaps historically plausible, highlights a time inconsistency problem. Rational public investors should have anticipated this volte-face. Expecting a future erosion of shareholders' property rights, they should have been loath to provide the first generation of entrepreneurs with capital on generous terms. This objection can be circumvented in several ways. First, public shareholders make mistakes and learn from experience. The statutory property rights protection most great reversal countries provided their first generation of public investors was weak, and public investors may have learned from experience not to offer equity capital on generous terms. Alternatively, the erosion may have been uncertain, for investors might have expected the enactment of strong property rights. Finally, public investors might have expected the erosion to occur many

years down the road. Perhaps the expected present value of insider expropriation at the time of the initial provision of finance was small. Such issues highlight the difficulty of constructing fully rational expectations equilibrium models of institutional development.

A simplification in our conceptual framework is that outsiders always prefer strong private property rights because the transfer and cost of capital effects are both positive for them and the competition effect is irrelevant. This may not be entirely realistic if organized labor prefers job security for members over general economic growth, as Roe (2003) and Högfeldt (2003) argue is the case in social democracies like Sweden. However, in such countries, we might think of organized labor as insiders too.

This, and all other simplifications in this section, highlight the need for rigorous theoretical development of this area, and for careful empirical work to guide theory. Developing models that formalize different flavors of capitalism is a fascinating uncharted territory for creative theorists.

\section{D: Determinants of Economic Entrenchment}

Economic entrenchment is a self sustaining, stable equilibrium that seems to characterize some, but not all oligarchic capitalist economies. The stark divergence between high and low income economies appears to result from the latter becoming trapped in a weak property rights regime characterized by economic entrenchment. This begs the questions of what determines whether or not any particular country falls into an economic entrenchment trap. We believe this to be a fundamental economic problem.

To determine whether or not economic entrenchment occurs, we must consider the circumstances under which the corporate insider is willing and able to pay the political insider 
sufficient side payments to reduce property rights protection, or to refrain from upgrading low protection, and outsiders are unable or unwilling to offer large enough side payments to oppose this. We propose three fundamental determinants: the nature of the investment opportunities available, the country's political, legal, and cultural traditions, and the country's openness to the global economy. We shall argue that oligarchs' lobbying preferences depend on the sorts of investment opportunities that are available to the oligarchs. We then argue that politicians' weighting of the public interest against personal gain depends on factors like the skewedness of the wealth distribution, legal and cultural traditions, and more ephemeral factors like democracy and openness.

\section{Opportunities and Traditions}

That the investment opportunities open to the oligarch help determine her lobbying preferences follows from the framework described above. There, we argued that the corporate insider is more able and willing to pay large side payments to political insider to implement weak private property rights if her existing operations generate larger cash flows and her future investment needs are less. In our terminology, the transfer effect is large, for large cash flows mean the corporate insider has abundant opportunities to appropriate wealth. To sustain these cash flows, the corporate insider views the competition effect associated with high private property rights as a negative. Also, the corporate insider has abundant internal cash to finance future investment, so the cost of capital effect is minor. Thus, the nature of the investment opportunities open to previous generations of oligarchs is a prime candidate as an explanation for current levels of property rights protection.

All else equal, lobbying by oligarchs should be more effective if political insiders value side payments more and economic growth less. In the stylized example above, this weighting is inherent in the parameters of the political insiders' utility function, though this is a vast over-simplification. Enumerating the likely determinants of the weights politicians assign to the public interest versus their personal gain requires further reflection. This relative valuation most plausibly depends on the country's political, legal, and cultural traditions.

Certainly, economic entrenchment in most modern countries implies an explicit or tacit collusion between public officials and the controlling owners of pyramidal groups. The objective of this collusion is policies that benefit established controlling owners, even at the cost of suppressing overall economic growth. Collusion can sometimes be difficult to sustain, as when members of a cartel "cheat" by undercutting each other secretly. However, collusion persists in other cases, such as trade protectionism and, we argue, oligarchic capitalism. As noted above, oligarchs are likely to be especially effective at lobbying for a variety of reasons. Because of this, they are likely to benefit more than the general citizenry from worse levels of official corruption.

The political insider's preferences presumably depend on the costs and benefits of taking bribes. An absence of democratic accountability, a high general level of corruption, a controlled press, and an ignorant, illiterate, and impoverished citizenry probably all can shift this balance towards accepting bribes. Of course, all of these factors are also outcomes, potentially caused by economic entrenchment. For example, Glaezer and Shleifer (2003) describe a "Curley Effect" in Boston politics, whereby its Irish-American Mayor James Michael Curley used wasteful redistribution and inflammatory rhetoric to drive more affluent and educated Anglo-Saxon voters out of Boston, thereby cementing his political control. Nonetheless, many authors argue persuasively that these sorts of factors are historically rooted and therefore exogenous in fundamental ways.

However, it is important to allow that such factors can also be endogenous, for this underlies a critical characteristic of entrenchment - its stability. The current cash flows to which the corporate insider has access, and the future cash flows her further investments might generate, certainly 
depend, to some extent at least, on exogenous "initial conditions". Corporate insiders with more experience in rent-seeking than in genuine entrepreneurship, as in some transition economies, might tend to favor weak property rights because these let them play to their advantage, inducing what Hellman et al. (2003) call state capture - the acquisition of control over the organs of the state by corporate oligarchs If such initial conditions induce weak institutions, these may well further limit future investment opportunities and alter political leaders' concern for the public interest. A path dependence ensues that may well lock in economic entrenchment.

Recent work provides considerable empirical evidence supporting this general reasoning. Nonetheless, much work remains, and this is likely to be an exciting avenue of future research.

Solokoff and Engerman (2000) propose such an argument based on a review of the economic history of the Americas from the sixteenth to the eighteenth century. They point out (p. 221) that plantation economies like the Barbados, Cuba, and Jamaica, which "specialized in the production of sugar and other highly valued crops associated with extensive use of slaves had the highest per capita income in the New World" in the sixteenth century, including slaves in the calculation. "The greater efficiency of the very large plantations and the overwhelming fraction of the populations that came to be black and slave made the distributions of wealth and human capital extremely unequal." "The long-run success and stability of the members of these elites (white plantation owners) were also facilitated by their disproportionate political influence. Together with the legally codified inequality intrinsic to slavery, the greater inequality in wealth contributed to the evolution of institutions that protected the privileged, even after the abolition of slavery."

A second category is Spanish America. These economies had valuable mineral resources and abundant native labor with low human capital. The Spanish colonial master built on pre-conquest social institutions, whereby Indian elites extracted tribute from the general population, to develop huge landholdings controlled by a small elite. This system locked in the status of the earliest settlers, who became formal representatives of the Spanish Crown, while restricting further settlement. The result is a highly unequal distribution of political and economic power.

In both of these categories of economies, institutional development was directed towards protecting the economic and political power of entrenched oligarchs, for example by limiting democracy, and limiting the economic and political power of the commoners, for example by spending little on basic public education. This is consistent with the oligarchs' existing investments generating high current cash flows, but with broader investment having relatively low returns to the oligarchs. This situation induced the oligarchs, the first wave of European settlement, to favor weak institutions, and this further limited the returns to further investment. The skewed wealth distribution that resulted from that economic system induced politicians to attach little weight to the interests of the common people, and thus further reinforced economic entrenchment.

Solokoff and Engerman (2000) contrast these two categories of economies with a third British North America. These areas, especially north of Virginia, had climates that did not favor large-scale plantations, and their development was based instead on small yeoman farmers and townsfolk of European descent who had relatively high and similar levels of human capital especially after settlement displaced the fur trade. Consequently, the areas that became Canada and the United States developed more egalitarian distributions of political power and institutions developed to provide more equal treatment and opportunities to their populations. As well, they spent far more on education for the population as a whole. These colonies presented limited opportunities for appropriation of cash flows by the first wave of settlers, but presented investment opportunities that promised abundant future returns. In this environment, the initial settlers favored 
property rights protection and sound institutions in general. The resulting relatively even distribution of wealth induced politicians to place a greater weight on the public interest.

Acemoglu, Johnson, and Robinson (2001) propose a different explanation as to how the initial conditions confronted by European settlers in different regions generated different investment opportunities and hence different property rights regimes. They examine the economic growth of British colonies to ascertain why some became rich and others did not. They argue that European settlers preferred institutions that enforced the rule of law and encouraged investment if they could survive and settle. In places where climatic conditions led to high settler mortality, Europeans preferred exploitative institutions. Taking European settlers' early mortality rate as an exogenous instrument, they find that low mortality encouraged European settlement; which induced early institutions supportive of the rule of law, public education, etc., which underlie current institutions. High settler mortality fostered "extractive" institutions, which also persist. They go on to show that current per capita income is higher the better the country's current protection against state expropriation, and that this in turn is highly negatively correlated with early settler mortality rates.

In a similar vein, Easterly and Levine (1997) use African data from the 1960s to the 1980s to show that ethnic diversity is related to slow growth. The idea is that ethnic fragmentation causes groups in power both to invest in competitive short-term "extractive" policies for fear of another ethnic group usurping power. Also, ethnic diversity, or more general political fragmentation, reduces the consensus for funding good public goods like infrastructure, education, and financial regulation. They provide robust supportive empirical evidence.

In addition, a natural tendency towards entrenchment might emerge as a country's entrepreneurs age and die. Entrepreneurs grown older and less dynamic might become less able to find and undertake innovative value creating investments. Or less capable heirs might assume control over great pyramidal groups, and miss opportunities their forebears would have grasped. Thus, the problem alluded to above and proposed in Rajan and Zingales (2003) sets in again, and corporate insiders come to better appreciate the advantages of weak private property rights.

Acemoglu, Johnson, and Robinson (2002, 2003) extend their previous work. Using urbanization to proxy for economic development, they demonstrate a "reversal of fortune" effect. Many countries that were relatively rich in 1500 are now relatively poor. They argue that this is inconsistent with a simple geographic or climatic story. Instead, they argue that "[i]n prosperous and densely settled areas, Europeans introduced or maintained already existing extractive institutions to force the large population and the slaves imported from Africa to work in mines and plantations." "In contrast, in previously sparsely settled areas, Europeans settled in large numbers and created institutions of private property ... [that] encourage commerce and industry." This institutional development made possible the spillover benefits associated with industrialization in the eighteenth and nineteenth centuries that built their current high standards of living.

Thus, the work by Solokoff and Engerman suggests that an initial round of investment opportunities creates either a skewed or egalitarian distribution of wealth, and that this in turn provides politicians with either an apolitical peasantry or a politically active middle class, respectively. The former allows politicians to place greater weight on their personal gain than does the later. Acemoglu, Johnson, and Robinson suggest that large populations of European settlers transplanted institutions supportive of the rule of law and property rights. The ensuing development of social and political traditions allows these institutions to persist. These considerations suggest the following considerations.

First, a tradition of democracy is probably important, see Barro (1991, 1997). If political insiders are elected to office, and if outsiders substantially outvote corporate insiders, political 
insider's utility should attach a lower weight to side payments than would be the case in the absence of democracy. Democratic traditions are the work of decades and centuries, and so are exogenous compared to more ephemeral economic phenomena.

Admittedly, political systems are probably not exogenous in the long run because corporate insider's lobbying targets might include the political process itself, as well as private property rights. Indeed, Engerman and Sokoloff (1997) and Sokoloff and Engerman (2000) argue that the colonial elites of Latin American countries, intent on controlling the state to control natural resources, actively opposed democracy to prevent the poor majority from gaining power and redistributing rents form these resources. Olson (2000) and others also argue that oligarchic elites dislike democracy. Rajan and Zingales (2003) suggest that the United States is largely immunized against economic entrenchment (which they call "an interest group theory of financial development") because of its multitudinous branches of government, which provide checks and balances, and because of the diversity and activity of interest groups.

Second, an efficient and independent judiciary raises the penalty for being caught accepting bribes, and so plausibly also shifts political insiders' cost-benefit analysis towards greater concern for economic growth. La Porta et al. (1998) and others propose that ancient legal traditions, established centuries or even millennia ago by colonial occupation, invasion, or economic domination, still influence levels of general corruption, judicial efficiency, and basic legal rights. La Porta et al. (1998) echo Hayek (1960) in proposing that, in civil law countries, where the law is directly under state control, the elite use the law to become entrenched. In contrast, common law traditions have more independent judiciaries that protect private property owners from the state ${ }^{20}$. See Beck et al. (2002) for empirical evidence consistent with this view.

But a country's legal traditions are clearly not the only factors that raise the costs of taking bribes. Another institution that we believe to be important is a free and independent press. A free press exposes and criticizes political insiders who value side payments more than social objectives. A free press also exposes controlling insiders' extraction of private benefits. Finally, a free press makes for more informed and less manipulability outsiders, and thus makes any lobbying they undertake more effective. Dyck and Zingales (2002) show that an independent and free press mitigates theft by corporate insiders. However, Djankov et al. (2003) show that the media virtually everywhere are controlled either by the State or by a few wealthy families. Where those families are part of the oligarchic elite, the watchdog role of the press may be seriously compromised.

Less quantifiable social institution also probably determines a country's propensity for economic entrenchment. For example, whether a country provides sound basic public education might matter. Better educated outsiders are better able to understand and participate in political debates. This presumably lowers outsiders lobbying costs relative to those of insiders. A better educated populace also presumably generates more capable and politically astute outsider entrepreneurs. Again, Engerman and Sokoloff (1997) and Sokoloff and Engerman (2000) argue that the colonial elite in Latin American actively opposed public investment in human capital to prevent the poor majority from gaining power and redistributing rents form natural resources.

Even less tangible institutions, like culture and mores, may also be important. Landes (1949) argues that the generally poor performance of the French economy compared to those of Germany, Great Britain, and the United States throughout the $19^{\text {th }}$ century was caused by a predominance of family control in France. He argues that French family firms were highly risk averse, and more

\footnotetext{
${ }^{20}$ Another difference between civil and common laws is that the latter has greater adaptability than the former in that it can adjust to changing social and economic circumstances more flexibly because the interpretation of common law codes is based on current values. For a discussion of the difference between civil and common laws, see Beck et al. (2002).
} 
interested in survival and succession than in growth and innovation. Thus, family businesses lobbied for protectionism and bailouts, and regarded the state as "a sort of father in whose arms [they] could always find shelter and consolation" (p. 50) with the result that overall economy is slow. Consistent with this, Murphy (2004) argues that French culture places a huge weight on each generation's sacred duty to pass on a patrimony to the next. Indeed, French Civil Law makes it virtually impossible for the patriarch of a family business to disinherit his son.

More generally, Weber (1958), La Porta et al. (1997a), and others argue that certain religions are more amenable to commerce and finance than others. Weber (1958) proposes that the Protestant religion, by emphasizing individual accountability, fostered a cultural shift that favored entrepreneurs over old-money elites. La Porta et al. (1997a) argue that hierarchical religions, which they define to include Roman Catholicism and Islam, are less conducive to the growth of large businesses. Like Weber, they emphasize the importance of cultural institutions that encourage individual initiative and cooperation among unrelated individuals. These characteristics embolden outsiders and limit popular acceptance of oligarchic rule.

Indeed, Rajan and Zinglaes (2003) point out that the financial atrophy, or "great reversals", they detect did not occur with equal intensity in all countries, and that many stock markets flourished through the entire twentieth century. They propose that different political, legal, and cultural traditions instill different degrees of susceptibility to economic entrenchment, much as certain genes create dispositions towards specific infirmities given the necessary environmental triggers.

Further research along the lines of all of the studies discussed above is likely to generate exiting new insights. We are only beginning to understand these very basic issues, which are fundamental not only to economics and finance, but to a whole spectrum of social sciences.

\section{Globalization}

One particularly rapidly changing aspect of the economic environment of many countries is openness to the global economy. European countries are merging into an ever closer economic and political union, regional free trade blocks and bilateral free trade treaties are much in vogue, and pressure continues for further multilateral action to reduce trade and capital flow barriers. Globalization merits special attention here, for the persistence of economic entrenchment requires a degree of economic autarky for several reasons.

First, autarchy preserves monopoly and monopsony power in product and factor markets in general. If domestic entrants can borrow abroad, list on foreign stock exchanges, or otherwise obtain capital from foreign investors, they can establish themselves despite ill functioning local capital markets and institutions. Henry $(2000 \mathrm{a}, \mathrm{b})$ reports a significant favorable impact of capital openness on the domestic cost of capital, and thus on investment. Coffee (2002), Karolyi and Stulz (2003), Stulz (1999), and Siegel (2003) discuss how cross-listing on foreign exchanges and submitting to foreign regulators can credibly signal investors about firm quality.

Second, autarky allows better control over the pace of creative destruction. Capital barriers can keep local innovators from developing their innovations, cutting into existing firms' markets, and accumulating wealth. Trade barriers can keep innovative foreign products out of domestic markets and thus preserve the value of existing capital assets. Suppressing domestic innovation is of no value if foreign innovators can flood the market with their products.

Third, autarchy gives governments much greater policy freedom. Confiscatory taxes, skewed regulations, inefficient subsidies, and other politically related private benefits of control are much harder to sustain in an open economy. And bilateral and multilateral treaties limit governments' 
powers to enact such policies. Moreover, footloose capital, skilled labor, and consumers can take their business elsewhere if the local economy becomes too distorted.

Finally, locals may imitate foreigners. Caves (1974) and a huge subsequent literature argue that entry by foreign multinationals raises productivity because of technology spillovers and heightened competition in both goods and factor markets. Locals may also come to demand the same financial and political rights they see foreigners enjoying. That is, openness may create popular support for institutional reform. Local governments and regulators may be pressed to adopt international best practices in disclosure, governance, and regulation.

For example, Stulz (1999) analyzes how openness alters domestic investors demand for better corporate governance. Locals can learn from foreign investors the skills to seek information about domestic companies and to monitor performance. Khanna and Palepu (2001) examine Indian firms and show that foreign investors identify better performing India firms and propose that their monitoring improves performance. Active foreign investors both train personal for domestic investors and serve as role models. Also, the presence of active investors raises the demand for information services, such as auditing and financial analysis. And foreign investors can active a dormant market for corporate control. All of this raises the net benefits to corporate insiders of providing good governance and lowers the cost of sending a "good governance" signal to investors.

Thus, economic openness, the freedom of locals to do business with foreigners, ought also to be numbered among private property rights; and economic autarchy is probably a lobbying goal of oligarchs seeking economic entrenchment.

While direct evidence of this is limited, circumstantial evidence is supportive. Faccio (2003) shows that economies in which the corporate and political elites have stronger blood ties also have more restrictions on cross-border capital flows. Morck et al. (2000) show that economies with more inherited billionaire wealth as a fraction of GDP have more restrictions on inward foreign direct investment. Rajan and Zingales (2003) find greater "great reversals", or financial atavism, in countries with more closed economies. They argue that dual openness, that is trade openness and capital flow openness, is essential to counter the forces that undermine capital market development. With only trade openness, industrial incumbents press for government subsidies as well as the maintenance of their privileged access to capitals. The end result is the sustained repression of domestic capital market development. Moreover, they argue that capital openness requires private property rights, for otherwise information asymmetry continues to mar domestic capital markets, preventing entry by locals too small to seek foreign capital and thus sustaining the dominance of the local oligarchs (meaning that the foreign capital will flow to the oligarch's companies). Rajan and Zingales (2003) use exports plus imports over GDP to proxy for trade openness, international capital flows to proxy for capital flow openness, and measures such as equity issues, the number of listed companies, and stock market capitalization to proxy for financial development. They report that trade openness heightens the positive impact of industrialization on financial development. They also note that this impact is much more important early in the twentieth century than in its latter decades. The impact disappears in the mid-century period when international capital mobility was limited, roughly from 1930 to the 1970 s.

Some direct evidence pertaining to changes in openness is available to support these arguments. Morck et al. (2000) show that the unexpected enactment of free trade with the United States caused the stock prices of Canadian firms controlled by old money families to fall relative to other Canadian stocks in the same industries. They also show that Canadian firms controlled by old money families had abnormally high capital intensity prior to free trade, but that their capital intensity fell to industry, firm size, and firm age corrected norms subsequent to free trade. Johnson 
and Mitton (2003) show that, when the Malaysian government imposed capital controls in 1998 in response to allegations that foreign "hot money" caused the East Asian economic crisis, the stock prices of firms with ties to the ruling party rose and the stock prices of other firms fell. Their result suggests that capital controls create a screen for cronyism, in which the government forwards resources to connected firms via their policies. However, Siegel (2003a) finds that increasing openness in Korea primarily expanded and strengthened that countries' most politically connected firms. Further evidence is needed to clarify the issue.

The arguments of Morck et al. (2000), Johnson and Mitton (2003), and Rajan and Zingales (2003) suggest that openness to global capital flows, as well as to international trade, ought to augment national economic performance. However, other students of international finance disagree out of concern that capital market openness might heighten economic volatility. For example, Bhagwati (1998) argues that capital market openness can spread financial crises, and Forbes and Rigobon (2002) study contagion as a factor in market fluctuations. Be this as it may, avoiding economic entrenchment clearly counts as a serious weight on the side of the balance favoring capital openness. Further work exploring this issue is likely to be of considerable value.

\section{Endowments, Institutions, and Policies}

Easterly and Levine (2003) compare the economic significance of the three broad classes of determinants discussed above by contrasting three hypotheses. The first they call an "endowments hypothesis" - that variables like settler mortality, latitude, natural resources, and access to the sea matter most in explaining general prosperity. The second, which they style an "institutions hypothesis", focuses on private property rights, accountability, political stability, government effectiveness, regulatory burden, rule of law, and an absence of corruption. The third, which they call a "public policy hypothesis", holds that more standard economic variables like inflation, trade openness, and exchange rate overvaluation.

Using the logarithm of 1995 real per capita GDP as their dependent variable in multiple regressions, they report that endowments explain economic growth, with natural resources and mortality rate the most significant factors. They also find that endowments help explain cross country variation in institutional development, with natural resources and mortality rate again the most significant factors; and that endowments do not explain growth except through their influence on institutions. Finally, they report that policy variables do not explain growth once the institutional effects are accounted for.

The Easterly and Levine (2003) study is valuable not only for the empirical facts it provides, but for demonstrating how researchers can test the importance of different theoretical and conceptual explanations for these issues. We anticipate a large literature developing along these lines.

\section{F. Summary}

This section proposes the concept of economic entrenchment as a feedback loop, whereby weak institutions place sweeping corporate governance powers in the hands of a tiny elite, who then lobby for weak institutions. We further propose that this feedback loop creates economic distortions that retard economic growth. These proposals require elaboration.

Several core concepts underlie the idea of economic entrenchment. First, entrusting the corporate governance of the greater part of a country's corporate sector to a tiny elite, especially via control pyramids, gives that elite huge advantages in political lobbying. Second, oligarchs often lobby for weak property rights because these increase the private benefits of control they can appropriate from outside investors. Thus, the elite prefer strong private property rights only under 
some circumstances, while the rest of the population always prefers strong private property rights. Third, economic entrenchment requires that political insiders see the benefits of cooperating with the oligarchs as outweighing the costs, despite the detrimental effects inflicted upon the populace in general.

This framework does not imply that economic entrenchment is inevitable. The elite and the general citizenry might both prefer strong property rights, particularly when the future economic outlook is bright so that the elite need external financing. However, the framework does suggest a high degree of path dependence. An historical shock that induced economic entrenchment in the past could have a long lasting effect on a country's institutional development; for once in place, economic entrenchment can be self-sustaining in the absence of further shocks.

The discussion in this section is deliberately speculative; and the subject matter is important. The development and preservation of institutions conducive to efficient resource allocation is a central issue in any market economy. Our central idea is that economists ought to pay more attention to how institutional development, as a political economy issue, is related to the distribution of corporate control in an economy. Corporate control provides resources and power to influence institutional development. The whole body of economics suggests that such resources and power would be used to further the self-interest of those who wield them. The preliminary work surveyed above shows that the initial distribution of economic power and the preferences for institutional development of the powerful both matter. Further work to determine how they matter, and why they might matter more under some circumstances than under others, would be most valuable.

The discussion above also suggests that the development of political, legal, and cultural institutions plays a role in these issues. Democracy, the rule of law, a free press, comprehensive public education, and individualistic cultures all raise political insiders' potential costs attendant with accepting bribes from corporate insiders. These factors are all thus conducive to the development of strong property rights protection for investors, and hence to capital market development. The literature, while still developing, suggests that conditions deep in a country's economic history that strengthened or weakened these sorts of institutions might either lock oligarchic capitalism and economic entrenchment into place or open the way to rapid economic growth and more diffuse capitalism. The extent to which corporate control and the political influence it engenders are path dependent is of great interest, for on this question turn issues regarding economic development strategies, and the most basic economic issue of all - why some countries are rich and others poor.

Recent work, notably Acemoglu et al. (2001, 2002, 2003), Engerman and Sokoloff (1997), Easterly and Levine (2003), Rajan and Zingales (2003), highlights the importance of an initial distribution of economic power, the preferences of those exercising it, and the path dependence of institutional development. Still, the research agenda is long and far from complete. We know little about which is more important - initial conditions or elite preferences. We know little about how that balance varies across countries and over time. Much important work remains undone.

We speculate that the preferences of entrenched elites regarding institutional development depend on their expected future need for broader cooperation - for example in tapping external financing to undertake future economic opportunities. But further work is needed to confirm this, and to clarify the tradeoffs involved. The success of those entrusted with corporate governance powers in influencing institutional development doubtless depends on existing institutions - social, political, judicial, and educational institutions. These determine the effectiveness and nature of successful lobbying strategies as well as the payoffs available to political insiders. In turn, these social, political, and judicial institutions are surely endogenous. We have severely limited 
theoretical and empirical understanding about the actual mechanics of how these interactions play out. Further work - conceptual, theoretical, and empirical - is needed.

For example, while we are beginning to understand the importance of legal traditions in determining the property rights of outside investors, we have little understanding of other ways in which legal traditions might matter. For example, we have barely scratched the surface in learning how different legal systems affect the distribution of corporate governance powers and the development of social, political, judicial, and educational institutions, not to mention the complicated interactions between these factors, Yet all of these almost certainly affect the political economy equilibrium, which determines property rights institutions among other things.

Better knowledge about the strategic alternatives and their payoffs to the political economic game players in these interactions would be very useful. For example, Dyck and Zingales (2002), Djankov et al. (2003), and others shows that the mass media are a key factor that affects social transparency and thus mitigates legitimized thievery and rent-seeking. Further work to shed lights on other factors that limit the players' strategic options would be welcome.

Rigorous theoretical models of this political economy game are likely to run up against several difficulties. For example, Rajan and Zingales (2003) mention an apparent time inconsistency in institutional change. How should investors in a strong property rights institutional environment deal with the possibility that property rights might be weakened in the future? Do investors buy stocks in emerging markets as ways of betting on those countries developing good institutions? This might explain some of the findings of Morck, Yeung and Yu (2000). But we have little real understanding of how stable property rights regimes are, and what contributes to their stability.

Also, because institutions evolve slowly, or in infrequent bursts of rapid change, we currently mostly rely on cross country studies. As Acemoglu, Johnson, Robinson, Engerman, Sokoloff demonstrate, historical studies can be illuminating. Assembling either cross country and historical data is labor intensive. One way of mitigating this problem is for researchers to share their data where possible. Another is to undertake detailed historical studies of individual countries' institutions. Yet another might be to conduct economic experiments to investigate the political economy of institutional development.

Finally, many of the studies discussed above - especially in this last section - use variables and concepts more commonly associated with anthropology, sociology, political science, or other social sciences than with economics and finance. Yet borrowing from other fields might well help economists gain a deeper understanding of institutions, and of the extent to which they really are creatures of economics.

\section{Conclusion}

Economic growth appears to be related to the distribution of control over an economy's corporate assets. The literature reveals that outside of the United States and United Kingdom, most large corporations have controlling owners who are often very wealthy families. Using pyramidal structures, cross shareholding, super voting rights, such a family typically controls many listed companies via a control pyramid. Control pyramids drive a wedge between such families' dominant control rights and their often miniscule actual investments in companies they control.

This separation apparently often leads to the simultaneous presence of two well known corporate governance problems: a divergence of the interests of the controlling shareholder from that of public shareholders and the entrenchment of the controlling shareholder. The controlling owner can liberally utilize corporate resources they do not own to fund private benefits with no fear of a shareholder revolt or hostile takeover. By orchestrating intercorporate transactions at artificial 
prices, the controlling owner can tunnel wealth between pyramid firms to generate greater private benefits. The consequence is inefficient resource allocation at the firm level.

In many countries, large pyramidal groups effectively entrust the corporate governance of substantial parts of their corporate sectors to a few extremely wealthy families. This can potentially magnify the poor governance of a few family patriarchs into inefficient economy-wide capital allocation, reduced investment in innovation, and retarded economic growth. Moreover, to preserve the status quo, these elite families sometimes appear able to influence public policies so as to curtail private property rights development, capital market development and economic openness. We dub this situation economic entrenchment. We argue that much existing work points to economic entrenchment as a significant issue in many countries. We then present a conceptual political economy framework that both defines economic entrenchment and conditions under which it can take hold.

While we develop our arguments in the context of wealthy families with extensive control pyramids, it is important to stress that the fundamental concept of entrenchment is more general. Tiny elites of professionals managers running keiretsu corporate groups in Japan, or of bureaucrats running state controlled pyramids in France, might also be entrenched. The essential issue is the negative consequences for growth of entrusting an economy's capital allocation to a tiny elite that cannot be sacked.

Our literature survey also suggests several key issues.

First, the archetypal corporate governance problem in the modern United States economy, a conflict between atomistic shareholders and professional managers does not generalize to most other countries. Rather, large firms in most countries are typically organized into pyramidal groups controlled by a few wealthy families. The ensuing corporate governance problem is conflict between the controlling shareholder of the pyramidal group and public shareholders.

Second, the distribution of control over the corporate sector affects economic development. Such highly concentrated control over corporate assets plausibly leads to a range of market power distortions, especially in capital markets. It also may curtail investment in innovation and augment rent-seeking. All of these effects likely retard economic growth.

Third, public policy regarding important issues like property rights, the development of financial markets and institutions, and economic openness, is usefully thought of as a political economy outcome. From this perspective, "public policy" in many countries cannot be considered a discretionary variable that can be "adjusted" to cure economic ills. Rather, it seems important to try to identify those factors that are "adjustable" and that might lead to a transition of the political economy from a suboptimal to a better equilibrium. Further empirical and theoretical that clarifies these issues is likely to be of first order importance.

\section{References}

Acemoglu, Daron and James A. Robinson. 2000. Economic Backwardness in Historical Perspective. National Bureau of Economic Research working paper 8831.

Acemoglu, Daron, Simon Johnson, and James A. Robinson. 2001. "The Colonial Origins of Comparative Development: An Empirical Investigation," American Economics Review 91:5, pp. 1369 - 1401.

Acemoglu, Daron, Simon Johnson, and James A. Robinson. 2002. "Reversal of Fortune: Geography and Institutions in the Making of the Modern World Income Distribution," Quarerly Journal of Economics 117:4, pp. $1231-94$.

Acemoglu, Daron, Simon Johnson, and James A. Robinson. 2003. "Understanding Prosperity and Poverty: Geography, Institutions and the Reversal of Fortune," mimeo, MIT (Feb 20 2003).

Aghion, Philippe, Eve Caroli, and Cecilia Garcia-Penalosa. 1999. "Inequality and Economic Growth: the Perspective of the New Growth Theories," Journal of Economic Literature 37:4, pp. 1615 - 60. 
Agnblad, Jonas, Erik Berglöf, Peter Högfeldt, and Helena Svancar. 2001. "Ownership and Control in Sweden: Strong Owners, Weak Minorities, and Social Control," in The Control of Corporate Europe. Fabrizio Barca and Marco Becht, eds. Oxford: Oxford U. Press, pp. 228-258.

Aikawa,Yoshisuke. 1934. New Capitalism and Holding Companies, Tokyo Bankers Association.

Aitken, Brian and Ann Harrison. 1999. "Do Domestic Firms Benefit from Direct Foreign Investment? Evidence from Venezuela," American Economic Review, 89:3, pp. 605 - 18.

Aitken, Brian, Ann Harrison, and Robert Lipsey. 1996. "Wages and Foreign Ownership, a Comparative Study of Mexico, Venezuela, and the USA," Journal of International Economics 40:3-4, pp. 345-371.

Allen, Jeffrey W. and Gordon M. Phillips. 2000. "Corporate Equity Ownership, Strategic Alliances, and Product Market Relationships,” Journal of Finance 55:6, pp. 2791-2815.

Almazan, Andres and Javier Suarez. 2003. "Entrenchment and Severance Pay in Optimal Governance Structures," Journal of Finance 58:2, pp. 519-47.

Almeida, Heitor and Daniel Wolfenzon. 2003a. "A Theory of Pyramidal Ownership and Family Business Groups," Stern NYU Working paper.

Almeida, Heitor and Daniel Wolfenzon. 2003b. "Equilibrium Costs of Efficient Internal Capital Markets," Stern NYU Working paper.

Anderson, Ronald C. and David M. Reeb. 2003a. "Family Ownership, Corporate Diversification, and Firm Leverage," Journal of Law and Economics 46, pp. 653-684.

Anderson, Ronald C. and David M. Reeb. 2003b. "Founding Family Ownership and Firm Performance: Evidence from the S\&P 500," Journal of Finance 58:3, pp. 1301-1328.

Anderson, Ronald C., Mansi A. Sattar and David M. Reeb. 2003. "Founding Family Ownership and the Agency Cost of Debt." Journal of Financial Economics 68:2, pp. 263-285.

Attig, Najah, Klaus Fischer and Yoser Gadhoum. 2003. "On the Determinants, Costs, and Benefits of Pyramidal Ownership: Evidence on Expropriation of Minority Interests," working paper.

Attig, Najah, Yoser Gadhoum and Larry Lang. 2003. "Bid-Ask Spread, Asymmetric Information and Ultimate Ownership," working paper.

Bae, Kee-Hong, Jun-Koo Kang and Jin-Mo Kim. 2002. "Tunneling or Value Added?" Evidence from Mergers by Korean Business Groups," Journal of Finance 57:6, pp. 2695- 2740.

Baek, Jae -seung, Jun-Koo Kang, and Kyung Suh park. 2004. Corporate Governance and Firm value: Evidence from the Asian Crisis. Journal of Financial Economics forthcoming.

Baker, George P. 1992. "Beatrice: A Study in the Creation and Destruction of Value," Journal of Finance 47:3, pp. 1081-1120.

Barca, Fabrizio and Marco Becht. 2001. The Control of Corporate Europe. Oxford: Oxford University Press.

Barclay, Michael J, Clifford G. Holderness, and Jeffery Pontiff. 1993. "Private benefits from block ownership and discounts on closed-end funds" Journal of Financial Economics 33:3, pp. 263-291.

Barclay, Michael J. and Clifford G. Holderness. 1989. "Private Benefits of Control of Public Corporations," Journal of Financial Economics 25:2, pp. 371-395.

Barro, Robert. 1991. "Economic growth in a Cross Section of Countries," Quarterly Journal of Economics 106:2, pp. 407-43.

Barro, Robert. 1997. Determinants of Economic Growth, A Cross-Country Empirical Study. MIT Press.

Bebchuk, Lucien Arya and Christine Jolls. 1999. "Managerial Value Diversion and Shareholder Wealth," Journal of Law, Economics and Organization 15:2, pp. 487-502.

Bebchuk, Lucien, Reinier Kraakman, and George Triantis. 2000. "Stock Pyramids, Cross-Ownership, and Dual Class Equity: the Mechanisms and Agency Costs of Separating Control from Cash-flow Rights," in Concentrated Corporate Ownership. Randall Morck ed. National Bureau of Economic Research Conference Volume, University of Chicago Press. Also circulated as National Bureau of Economic Research working paper \#6951.

Bebchuk, Lucien. 1999. "A Rent-Protection Theory of Corporate Ownership and Control," National Bureau of Economic Research working paper 7203.

Beck, Thorsten, Asli Demirguc-Kunt and Ross Levine, 2002. "Law and Finance: why Does Legal Origin Matter?," NBER Working Papers 9379 (December).

Beck, Beck, Thorsten., Ross Levine, and Norman Loayza. 2000. "Finance and the Sources of Growth," Journal of Financial Economics 58:1-2, pp. 261-300.

Bennedsen, Morten and Daniel Wolfenzon. 2000. "The Balance of Power in Close Corporations," Journal of Financial Economics 58:1-2, pp. 113-140.

Berglof, Erik and Enrico Perotti. 1994. "The Governance Structure of the Japanese Financial Keiretsu," Journal of Financial Economics 36:2, pp. 259-284. 
Bergstrom, Clas and Kristian Rydqvist. 1990. "The Ownership of Equity in Dual Class Firms," Journal of Banking and Finance 14:2-3, pp 255-69.

Bergstrom, Clas and Kristian Rydqvist.1992. "Differentiated Bids for Voting and Restricted Voting Shares in Public Tender Offers," Journal of Banking and Finance 16:1, pp. 97-114.

Berle, Adolph A. and Gardiner C. Means. 1932. The Modern Corporation and Private Property. New York: The McMillan Company.

Bertrand, Marianne, Paras Mehta, and Sendhil Mullainathan. 2002. "Ferreting out tunneling: An application to Indian business groups," Quarterly Journal of Economics 117:1, pp. 121-48.

Bhagwati, Jagdesh. 1998. "The Capital Myth: The Difference between Trade in Widgets and Trade in Dollars," Foreign Affairs 77:3, pp. 7-12.

Bianchi, Marco., Magda Bianco, and Luca Enriques. 2001. "The Separation Between Ownership and Control in Italy," mimeo, Bank of Italy.

Billett, Matthew T. and David C. Mauer. 2000. "Diversification and the Value of Internal Capital Markets: The case of Tracking Stock," Journal of Banking \& Finance 24:9, pp. 1457-90.

Black, Bernard, Reinier Kraakman and Anna Tassarova. 2000. "Russian Privatization and Corporate Governance: What Went Wrong?" Stanford Law Review 52, pp. 1731-1808.

Boyd, John H; Prescott, Edward C. 1986. "Financial Intermediary Coalitions," Journal of Economic Theory 38:2, pp. 211-32.

Brunello G, Graziano C, Parigi B.M. 2003. "The CEO Turnover in Insider-Dominated Boards: The Italian Case," Journal of Banking and Finance 27:6, pp. 1027-1051.

Burkart, Mike, Fausto Panunzi and Andrei Shleifer. 2003. “Family Firms,” Journal of Finance 58:5, pp. 2167-2201.

Carkovic, Maria and Ross Levine. 2002. "Does Foreign Direct Investment Accelerate Economic Growth?" paper presented at the World Bank conference (May 30-31, 2002), Financial Globalization: A Blessing or a Curse.

Caselli, Francesco and Nicola Gennaioli. 2003. Dynastic Management. National Bureau of Economic Research working paper 9442 (January).

Castro, Rui, Gian Luca Clementi and Glenn MacDonald. 2003. "Investor Protection, Optimal Incentives, and Economic Growth," Working Paper Stern.

Caves, Richard E., 1974. "Multinational Firms, Competition, and Productivity in Host-Country Markets," Economica 41:162, pp. 176-193

Choi, Dosoung. 1991. Toehold Acquisitions, Shareholder Wealth, and the Market for Corporate Control. Journal of Financial and Quantitative Analysis 26(3) 391408.

Claessens Stijn, Simeon Djankov, Larry H.P. Lang. 2000. "The Separation of Ownership and Control in East Asian Corporations," Journal of Financial Economics 58:1-2, pp. 81-112.

Claessens, Stjin, Simeon Djankov, Joseph Fan, and Larry Lang. 2002. "Disentangling the Incentive and Entrenchment Effects of Large Shareholdings," Journal of Finance 57:6, pp. 2741-2771.

Coase, Ronald. 1937. "The Nature of the Firm," Economica X, pp.386-405.

Coffee, John, 2001. "Do Norms Matter? A Cross-country Examination of Private Benefits of Control," Columbia University Law School Working Paper.

Coffee, John. 2002. "Competition Among Securities Markets: A Path Dependent Perspective. Columbia Law and Economics," Working Paper No. 192.

Cull, Robert, Jana Matesova and Mary Shirley. 2002. "Ownership and the Temptation to Loot: Evidence from Privatized Firms in the Czech Republic," Journal of Comparative Economics 30:1, pp. 1-24.

Daniels, Ron, Randall Morck and David Stangeland. 1995. "High Gear: A Case Study of the Hees-Edper Corporate Group," in Corporate Decision Making in Canada. R. Daniels and R. Morck, eds. Calgary:Industry Canada and the University of Calgary Press.

De Jong, Abe and Chris Veld. 2001. "An Empirical Analysis of Incremental Capital Structure Decisions under Managerial Entrenchment" Journal of Banking and Finance 25:10, pp. 1857-95.

De Long, J Bradford. 1990. "Did J. P. Morgan's Men Add Value? A Historical Perspective on Financial Capitalism," National Bureau of Economic Research Working Paper: 3426.

De Soto, Hernando. 1989. The Other Path: The Invisible Revolution in the third Words. New York: Harper and Row Publishers.

De Soto, Hernando. 2000. The Mystery of Capital: Why Capitalism Triumphs in the West and Fails Everywhere Else. New York: Basic Books.

Denis, Diane K; John J. McConnell. 2003. "International Corporate Governance," Journal of Financial and Quantitative Analysis 38:1, pp. 1-36. 
Diamond, Douglas W. 1984. "Financial Intermediation and Delegated Monitoring," Review of Economic Studies 51:3, pp. 393-414.

Djankov, Simeon, Clara McLeish, Tatiana Nenova, and Andrei Shleifer. 2003. "Who Owns the Media?" Journal of Law and Economics, forthcoming.

Djankov, Simeon, Rafael La Porta, Florencio Lopez-de-Silanes, and Andrei Shleifer. 2002. "The Regulation of Entry," Quarterly Journal of Economics 117:1, pp. 1-37.

D'Souza, Julia and John Jacob. 2000. "Why firms issue targeted stock," Journal of Financial Economics 56:3, pp. 459483

Durnev, Art, Randall Morck, and Bernard Yeung. 2000. "Does firm-specific information in stock prices guide capital allocation?" NBER Working Paper No. 8093.

Durnev, Art, Randall Morck, and Bernard Yeung. 2004. "Value Enhancing Capital Budgeting and Firm-Specific Stock Returns Variation," Journal of Finance, forthcoming.

Dyck, Alexander and Luigi Zingales. 2003. "Private Benefits of Control: an International Compaison," Journal of Finance, forthcoming.

Dyck, Alexander and Luigi Zingales.2002. "The Corporate Governance Role of the Media," in The Right to Tell: The Role of Mass Media in Economic Development. Roumeen Islam, ed. Washington: The World Bank.

Easterly, William and Ross Levine. 1997. Africa's growth tragedy: Policies and ethnic divisions. Quarterly Journal of Economics 112(4) 1203-51.

Easterly, William, and Ross Levine. 2003. "Tropics, Germs, and Crops: How Endowment Influence Economic Development," Journal of Monetary Economics 50:1, pp. 3-39.

Easterly, William. 2002. "Inequality does cause underdevelopment: New Evidence from Commodity Endowments, Middle Class Share, and Other Determinants of Per Capita Income," NYU working paper.

Edwards, Jeremy, and Klaus Fischer. 1994. Banks, Finance and Investment in West Germany since 1970. Cambridge, U.K.: Cambridge University Press.

Engerman, Stanley and Kenneth Sokoloff. 1997. "Factor Endowments, Institutions, and Differential Paths of Growth Among New World Economies: a View from Economic Historians of the United States," in How Latin America Fell Behind. Stephen Haber, ed. Stanford CA: Stanford University Press.

Faccio, Mara and Larry H.P. Lang. 2002. "The Ultimate Ownership in Western European Corporations," Journal of Financial Economics 65:3, pp. 365-395.

Faccio, Mara. 2003. "Politically Connected Firms," Working Paper Vanderbilt University

Federov, Oleg. 2000. "Case Studies on Abusive Self-Dealing." OECD/World Bank Corporate Governance Roundtable for Russia, February 24-25.

Fields, L Paige and Eric Mais. 1994. "Managerial Voting Rights and Seasoned Public Equity Issues," Journal of Financial and Quantitative Analysis 29:3, pp. 445-58.

Filatotchev, Igor, Mike Wright, and Michael Bleaney. 1999. "Privatization, Insider Control and Managerial Entrenchment in Russia," Economics of Transition 7:2, pp. 481-504.

Forbes, Kristin and Roberto Rigobon. 2002. "No contagion, Only Interdependence: Measuring Stock Market Comovements," Journal of Finance 57:5, pp. 2223-62.

Friedman, Eric, Simon Johnson and Todd Mitton. 2003. Tunneling and Propping. Journal of Comparative Economics 31(4) 732-750.

Gertner, Robert H., David S. Scharfstein, and Jeremy C. Stein. 1994. "Internal Versus External Capital Markets." Quarterly Journal of Economics 109:4, pp. 1211-30.

Gigler, Frank and Thomas Hemmer. 2002. "Informational Costs and Benefits of Creating Separately Identifiable Operating Segments," Journal of Accounting \& Economics 33:1, pp 69-90.

Glaezer, Edward and Andrei Shleifer. 2003. The Curley Effect. Harvard University working paper.

Glaezer, Edward, Jose Sheinkman, and Andrei Shleifer. 2003. The Injustice of Inequality. Journal of Monetary Economics 50(1) 199-222.

Gorton, Gary and Andrew Winton. 2003. "Financial Intermediation," in the Handbook of the Economics of Finance. George Constantinides, Milton Harris and Rene Stulz, eds. Amsterdam: North Holland.

Graham, Edward. 2003. Reforming Korea's Industrial Conglomerates. Institute for International Economics, Washington DC.

Grossman, Sanford J., and Joseph E. Stiglitz. 1980. "On the Impossibility of Informationally Efficient Markets," American Economic Review 70:3, pp. 393-408.

Hass, Jeffrey. 1996. "Directorial Fiduciary Duties in a Tracking Stock Equity Structure: The Need for a Duty of Fairness," Michigan Law Review 94:7, pp. 2089-2177.

Hayek, Friedrich. 1941. The Pure Theory of Capital. Chicago: University of Chicago Press. 
Hayek, Friedrich. 1960, The Constitution of Liberty: London: Routledge and Kegan Paul, Ltd..

Hellman, Joel, Geraint Jones, and Daniel Kaufmann. 2003. "Seize the State, Seize the Day: State Capture and Influence in Transition Economies," Journal of Comparative Economics 31(4) 751-773.

Henry, Peter B. 2000a. "Stock Market Liberalization, Economic Reform, and Emerging Market Equity Prices," Journal of Finance 55:2, pp. 529-564.

Henry, Peter B. 2000b. "Do Stock Market Liberalizations Cause Investment Booms?" Journal of Financial economics 58:1-2, pp. 301-334.

Hogfeldt, Peter. 2003. "The history and politics of corporate ownership in Sweden," Working Paper Stockholm School of Economics.

Holderness, Clifford, and Dennis Sheehan. 1988. "The Role of Majority Shareholders in Publicly Held Corporations: An Exploratory Analysis," Journal of Financial Economics 20:1-2, pp. 317-46.

Holderness, Clifford, Randall Kroszner, and Dennis P. Sheehan. 1999. "Were the Good Old Days That Good? Changes in Managerial Stock Ownership Since the Great Depression," Journal of Finance 54:2, pp. 435-69.

Hoshi, Takeo, Anil Kashyap, and David Scharfstein. 1991. "Corporate Structure, Liquidity, and Investment: Evidence from Japanese Industrial Groups," Quarterly Journal of Economics 106:1, pp. 33-60.

Jensen, Michael C. and William H. Meckling. 1976. "Theory of the Firm: Managerial Behavior, Agency Costs and Ownership Structure," Journal of Financial Economics 3:4, pp. 305-60.

Joh, Sung Wook. 2003. "Corporate Governance and Firm Profitability: Evidence From Korea Before the Economic Crisis," Journal of Financial Economics 68:2, pp. 287-322.

Johnson, Simon, and Todd Mitton. 2003. "Cronyism and Capital Controls: Evidence from Malaysia," Journal of Financial Economics 67:2, pp. 351-82.

Johnson, Simon, Peter Boone, Alasdair Breach and Eric Friedman. 2000. "Corporate Governance in the Asian Financial Crisis," Journal of Financial Economics 58:1-2, pp. 14186.

Johnson, Simon, Rafael La Porta, Florencio Lopez-de-Silanes, and Andrei Shleifer. 2000. "Tunneling," American Economic Review 90:2, pp. 22-27.

Johnson, W. Bruce, Robert P. Magee, Nandu J. Nagarajan and Henry A. Newman. 1985. "An Analysis of the Stock Price Reaction to Sudden Executive Deaths: Implications for the Management Labor Market," Journal of Accounting and Economics 7:1-3, pp. 151-174.

Kang, David. 2002. "Bad Loans to Good Friends: Money Politics and the Developmental State in Korea," International Organization, forthcoming.

Karolyi, Andrew and Rene Stulz. 2003. "Are Financial Assets Priced Locally or Globally?" in the Handbook of the Economics of Finance. George Constantinides, Milton Harris, and Rene Stulz, eds. Amsterdam: North-Holland, pp. 975-1020.

Khanna, Tarun and Krishna Palepu. 1999a. "Policy Shocks, Market Intermediaries, and Corporate Strategy: Evidence of Business Groups from Chile and India," Journal of Economics and Management Strategy 8:2, pp. 271-310.

Khanna, Tarun and Krishna Palepu. 1999b. "The Right Way to Restructure Conglomerates in Emerging Markets," Harvard Business Review, July-August.

Khanna, Tarun and Krishna Palepu. 2000a. "Is Group Affiliation Profitable in Emerging Markets? An Analysis of Diversified Indian Business Groups," Journal of Finance 55:2, pp. 867-93. Formerly titled "Corporate Strategy and Institutional Context: An Empirical Analysis of Diversified Indian Business Groups." Harvard Business School Working Paper \#96-051.

Khanna, Tarun and Krishna Palepu. 2000b. "The Future of Business Groups in Emerging Markets: Long Run Evidence from Chile," Academy of Management Journal 43:3, pp. 268-285.

Khanna, Tarun and Krishna Palepu. 2001. "Emerging Market Business Groups, Foreign Investors, and Corporate Governance," in Concentrated Corporate Ownership. Randall Morck, ed. National Bureau of Economic Research Conference Volume. University of Chicago Press.

Khanna, Tarun, and Jan W. Rivkin, 2001, "Estimating the Performance Effects of Business Groups in Emerging Markets," Strategic Management Journal 22:1, pp. 45-74.

Khanna, Tarun. 2000. "Business Groups and Social Welfare in Emerging Markets: Existing Evidence and Unanswered Questions," European Economic Review 44:4-6, pp. 748-761.

Kim, Se-Jik. 2004. "Bailout and Conglomeration,” Journal of Financial Economics 71:X, pp. 315-347.

King, Robert G and Ross Levine. 1993. "Finance, Entrepreneurship, and Growth: Theory and Evidence," Journal of Monetary Economics 32:3, pp. 513-42.

Krueger, Anne O. 1993. "Virtuous and Vicious Circles in Economic Development," American Economic Review, Vol. 83, No. 2, (May), pp. 351-355. 
La Porta, Rafael, Florencio Lopez-de-Silanes, Andrei Shleifer and Robert Vishny. 1997a. "Trust in Large Organizations," American Economic Review 87:2, pp. 333-39.

La Porta, Rafael, Florencio Lopez-de-Silanes, Andrei Shleifer and Robert Vishny. 1997b. "Legal Determinants of External Finance," Journal of Finance 52:3, pp. 1131-50.

La Porta, Rafael, Florencio Lopez-de-Silanes, Andrei Shleifer and Robert Vishny. 1998. "Law and Finance," Journal of Political Economy. 106:6, pp. 1113-55.

La Porta, Rafael, Florencio Lopez-de-Silanes, Andrei Shleifer and Robert Vishny. 1999. "Corporate Ownership around the World," Journal of Finance 54:2, pp. 471-517.

Landes, David. 1949. "French Entrepreneurship and Industrial Growth in the Nineteenth Century," Journal of Economic History 9, pp. 45-61.

Lease, Ronald C., McConnell, John and Mikkelson, Wayne. 1983. "The Market Value of Control in Publicly-Traded Corporations," Journal of Financial Economics. 11:1-4, pp. 439-71.

Lease, Ronald, McConnell, John and Mikkelson, Wayne. 1984. "The Market Value of Differential Voting Rights in Closely Held Corporations," Journal of Business. 57:4, pp. 443-67.

Leff, Nathaniel. 1976. "Capital Markets in the Less Developed Countries: The Group Principle," in Money and Finance in Economic Growth and Development. R. McKinnon, ed. New York: Marcel Dekker.

Leff, Nathaniel. 1978. "Industrial Organization and Entrepreneurship in the Developing Countries: The Economic Groups," Economic Development and Cultural Change 26:4, pp.661-75.

Lemmon, Michael L. and Karl V. Lins, 2003 "Ownership Structure, Corporate Governance, and Firm Value: Evidence from the East Asian Financial Crisis," Journal of Finance 58:4, pp. 1445-1468.

Lenway, Stephanie, Morck, Randall and Bernard Yeung. 1996. "Rent Seeking, Innovation and Protectionism and the American Steel Industry: An Empirical Study," Economic Journal. 106(435) 410-421.

Levine, Ross, 1997. "Financial Development and Economic Growth: Views and Agenda," Journal of Economic Literature 35:2, pp. 688-726.

Levy, Haim. 1983. "Economic Evaluation of Voting Power of Common Stock," Journal of Finance 38:1, pp. 79-93.

Lewellen, Wilbur G. 1971. "A Pure Financial Rationale for the Conglomerate Merger," Journal of Finance 26:2, pp. 521-37.

Lins, Karl. 2003. "Equity Ownership and Firm Value in Emerging Markets," Journal of Financial and Quantitative Analysis 38:1, pp. 159-84.

Lombardo, Davide and Marco Pagano, 2002, "Law and Equity Markets: A Simple Model," in Corporate Governance Regimes: Convergence and Diversity, (eds. Joe McCahery, Pieter Moerland, Theo Raaijmakers and Luc Renneboog,) Oxford University Press, pp. 343-362.

Lopez-de-Silanes, Florencio. 1997. "Determinants of Privatization Prices," Quarterly Journal of Economics 112:4, pp. 965-1025.

Mankiw, N. Gregory. 1995. "The Growth of Nations,” Brookings Papers on Economic Activity 1, pp. 275-310.

Megginson, William L. and Jeffry M. Netter. 2001, "From State to market: a Survey of Empirical Studies on Privatization," Journal of Economic Literature, Vol.39, (June) pp. 321-389

Mikkelson, Wayne H., and Richard Ruback. 1985. "An Empirical Analysis of the Interfirm Equity Investment Process," Journal of Financial Economics. December 1985; 14:4, pp.523-53.

Mitton, Todd. 2002. "A Cross Firm Analysis of the Impact of Corporate Governance on the East Asian Financial Crisis," Journal of Financial Economics 64:2, pp. 215-41.

Morck, Randall and Masao Nakamura. 1999. Banks and Corporate Control in Japan. Journal of Finance 54(1) 319-40.

Morck, Randall, and Bernard Yeung. 2003. "Family Control and the Rent-Seeking Society," Entrepreneurship: Theory and Practice, forthcoming.

Morck, Randall, and Masao Nakamura. 2004. "Been There, Done That: A History of Corporate Ownership in Japan," NBER Working Paper \#. (presented in NBER 2003 Corporate Governance History Conference, Banff, Canada.

Morck, Randall, Andrei Shleifer and Robert Vishny. 1988. "Management Ownership and Market Valuation: An Empirical Analysis," Journal of Financial Economics, 20: 1/2, pp. 293-315.

Morck, Randall, Andrei Shleifer and Robert W. Vishny. 1989. "Alternative Mechanisms for Corporate Control," American Economic Review. 79:4, pp. 842-852.

Morck, Randall, Bernard Yeung, and Wayne Yu. 2000. 'The Information Content of Stock Markets: Why do Emerging Markets Have Synchronous Stock Price Movements?” Journal of Financial Economics 58:1-2, pp. 215-60.

Morck, Randall, David Stangeland, and Bernard Yeung. 2000. "Inherited Wealth, Corporate Control, and Economic Growth: The Canadian Disease," in Concentrated Corporate Ownership. Randall Morck, ed. National Bureau of Economic Research Conference Volume. University of Chicago Press. Also circulated as National Bureau of Economic Research working paper \#6814 (1998). 
Morck, Randall, Kathy He and Bernard Yeung. 2002. "Stability," Unpublished manuscript.

Morck, Randall, Masao Nakamura, and Anil Shivdasani. 2000. "Banks, Ownership Structure, and Firm Value in Japan," Journal of Business 73:4, pp. 539-68.

Morck, Randall. 1995. "The Economics of Concentrated Ownership," Canadian Business Law Journal 26:1, pp. 63-85.

Morck, Randall. 1996. "Revamping C.E.O. Stock Options," in Value for Money. In Edward Iacobucci, ed. C.D. Howe Institute. Toronto.

Morck, Randall. 1997. "The Corporate Governance Consequences of the Intercorporate Dividend Tax Exemption" Corporate Governance Review 6:9, pp. 9-12.

Murphy, Antoin. 2004. "The History of Corporate Ownership in France," paper presented at the NBER's History of Corporate Ownership Conference, June 21-22, at Lake Louise, Alberta, Canada.

Murphy, Kevin M., Andrei Shleifer, and Robert Vishny. 1991. The Allocation of Talent: Implications for Growth. Quarterly Journal of Economics. May. 503-530.

Murphy, Kevin., Andrei Shleifer, and Robert Vishny 1993. Why is Rent-seeking Costly to Growth? American Economic Review, May, 82(2) 409-414.

Nenova, Tatiana. 2003. "The Value of Corporate Voting Rights and Control: A Cross-Country Analysis," Journal of Financial Economics 68:3, pp. 325-51.

North, Douglass. 1991. Institutions. Journal of Economic Perspectives 5(1) 97-112

Olson, Mancur Jr. 1963. "Rapid Growth as a Destabilizing Force," Journal of Economic History 23:4, pp. 529-552.

Olson, Mancur Jr. 1982. The Rise and Decline of Nations. New Haven: Yale University Press.

Olson, Mancur Jr. 2000. Power and Prosperity: Outgrowing Communist and Capitalist Dictatorships. New York: Basic Books.

Perez-Gonzalez, Francisco, 2002, "Does Inherit Control Hurt Firm Performance," Working paper Columbia University.

Peterson, Mitchell A., and Raghuram G. Rajan, 1994. "The Benefits of Lending Relationships: Evidence from Small Business Data," Journal of Finance 49:1, pp. 3-37.

Prowse, Stephen D. 1992. "The Structure of Corporate Ownership in Japan," Journal of Finance 47:3, pp. 1121-40.

Rajan, Raghuram and Luigi Zingales. 1998. "Financial Dependence and Growth," American Economic Review 88:3, pp $559-86$.

Rajan, Raghuram and Luigi Zingales. 2003. "The Great Reversals: the Politics of Financial Development in the Twentieth Century," Journal of Financial Economics 69:1, pp. 5-50.

Rajan, Raghuram. 1992. "Insiders and Outsiders: The Choice between Informed and Arm's-Length Debt," Journal of Finance 47:4, pp. 1367-1400.

Roe, Mark. 2001. "Rents and their Corporate Law Consequences," Discussion paper, Columbia Law School.

Roe, Mark. 2003. Political Determinants of Corporate Governance. Oxford: Oxford University Press.

Roll, Richard. 1988. " $\mathrm{R}^{2}$," Journal of Finance 43:3, pp. 541-66.

Rydqvist, Kristian. 1996. "Takeover Bids and the Relative Prices of Shares That Differ in Their Voting Rights," Journal of Banking and Finance 20:8, pp. 1407-25.

Schumpeter, Joseph A. 1912. Theorie der Wirtschaftlichen Entwichlung, Leipzig, Dunker und Humbolt. Translation by R. Opie (1934), The Theory of Economic Development: An Inquiry into Profits, Capital, Credit, Interest, and the Business Cycle. Cambridge Mass: Harvard University Press.

Schumpeter, Joseph Alois. 1942. Capitalism, Socialism, and Democracy. New York, Harper \& bros.

Shleifer Andrei and Robert Vishny 1993 "Corruption," Quarterly Journal of Economics 108:3, pp. 599-617.

Shleifer, Andrei and Daniel Wolfenzon. 2002. "Investor Protection and Equity Markets," Journal of Financial Economics 66:1, pp. 3-27.

Shleifer, Andrei and Robert Vishny 1994, "Politicians and Firms," Quarterly Journal of Economics 109:4, pp. 995-1025.

Shleifer, Andrei and Robert W. Vishny. 1986. "Large Shareholders and Corporate Control," Journal of Political Economy 94:3, pp. 461-88.

Shleifer, Andrei, and Robert Vishny. 1997. "A survey of Corporate Governance,” Journal of Finance 52:2, pp. 737-783.

Shleifer, Andrei. 1997. "Government in Transition,” European Economic Review 41(3-5) 385-410.

Siegel, Jordan I. 2003. "Can Foreign Firms Bond Themselves Effectively by Renting U.S. Securities Laws?” Journal of Financial Economics forthcoming.

Siegel, Jordan. 2003a. Is Political Connectedness a Paramount Investment After Liberalization? The Successful Leveraging of Contingent Social Capital and the Formation of Cross Border Strategic Alliances Involving Korean Firms and their Global Partners (1987-2000). Harvard Business School working paper.

Slovin, Myron B., Marie E. Sushka. 1993. "Ownership Concentration, Corporate-Control Activity, and Firm Value Evidence from the Death of Inside Blockholders," Journal of Finance 48:4, pp. 1293-1321. 
Smith, Brian F., and Ben Amoako-Adu, 1999, "Management Succession and Financial Performance of Family Controlled Firms," Journal of Corporate Finance, Vol. 5, pp. 341-68.

Sokoloff, Kenneth L. and Stanley L. Engerman. 2000. Institutions, Factor Endowments, and Paths of Development in the New World, Journal of Economic Perspectives 14:3, pp. 217-32.

Sonin, Konstantin. 2003. "Why the Rich May Favor Poor Protection of Property Rights," Journal of Comparative Economics 31(4) 715-731.

Stein, Jeremy, 1997, "Internal Capital Markets and the Competition for Corporate Resources," Journal of Finance 52:1, pp. 111-133.

Stigler, George. 1971. "The Theory of Economic Regulation.” Bell Journal of Economics and Management Science 2 Spring 3-21.

Stulz, René and Rohan Williamson. 2003. "Culture, Openness and Finance," Journal of Finance 70:3, pp.313-49.

Stulz, Rene M.. 1999. "Globalization, Corporate Finance and the Cost of Capital," Journal of Applied Corporate Finance, pp. 8-25.

Stulz, René. 1988. "On Takeover Resistance, Managerial Discretion and Shareholder Wealth," Journal of Financial Economics 20:1-2, pp. 25-54.

Tobin, James. 1982. "On the Efficiency of the Financial System," Lloyd's Banking Review 153, pp. 1-15.

Ugurlu, Mine. 2000. "Agency Costs and Corporate Control Devices in the Turkish Manufacturing Industry," Journal of Economic Studies 27:6, pp. 566-99.

Veblen, Thorstein. 1899. The Theory of the Leisure Class; an Economic Study in the Evolution of Institutions. London: Macmillan \& Co.

Veblen, Thorstein. 1904. The Theory of Business Enterprise. New York: C. Scribner's Sons.

Veblen, Thorstein. 1923. Absentee Ownership and Business Enterprise in Recent Times. New York: A. M. Kelley.

Volpin, Paolo F. 2002. "Governance with Poor Investor Protection: Evidence from Top Executive Turnover in Italy," Journal of Financial Economics 65:1, pp. 159-60.

Weber, Max. 1958. The Protestant Ethic and the Spirit of Capitalism. New York: Scribner's Press.

Williamson, Oliver. 1973. "Markets and Hierarchies: Some Elementary Considerations," American Economic Review 63:2, pp. 316-25.

Wurgler, Jeffrey. 2000. "Financial Markets and the Allocation of Capital," Journal of Financial Economics 58:1-2, pp. $187-214$.

Zingales, Luigi. 1994. "The value of the voting right: A study of the Milan stock exchange experience," Review of Financial Studies 7:1, pp. 125-48.

Zingales, Luigi. 1995a. "Insider Ownership and the Decision to Go Public," Review of Economic Studies 62:3, pp. 42548.

Zingales, Luigi. 1995b. "What Determines the Value of Corporate Votes?" Quarterly Journal of Economics 110:4, pp. 1047-1073. 